\title{
ANALYSIS OF FISSION PRODUCT BEHAVIOR IN THE SACLAY SPITFIRE LOOP TEST SSL-1
}

\author{
by \\ D. D. JENSEN, M. J. HAIRE, and A. BALLAGNY
}

Work supported in part under

Contract EY-76-C-03-0167

Project Agreement No. 17

for the San Francisco Operations Office

Department of Energy 


\title{
NOTICE
}

This report was prepared as an account of work sponsored by the United States Government. Neither the United States nor the Department of Energy, nor any of their employees, nor any of their contractors, subcontractors, or their employees, makes any warranty, express or implied, or assumes any legal liability or responsibility for the accuracy, completeness or usefulness of any information, apparatus, product or process disclosed, or represents that its use would not infringe privately owned rights

\author{
Printed in the United States of America \\ Available from \\ National Technical Information Service \\ U.S. Department of Commerce \\ 5285 Port Royal Road \\ Springfield, Virginia 22161 \\ Price: Printed Copy $\$ 6.50$; Microfiche $\$ 3.00$
}




\section{DISCLAIMER}

This report was prepared as an account of work sponsored by an agency of the United States Government. Neither the United States Government nor any agency Thereof, nor any of their employees, makes any warranty, express or implied, or assumes any legal liability or responsibility for the accuracy, completeness, or usefulness of any information, apparatus, product, or process disclosed, or represents that its use would not infringe privately owned rights. Reference herein to any specific commercial product, process, or service by trade name, trademark, manufacturer, or otherwise does not necessarily constitute or imply its endorsement, recommendation, or favoring by the United States Government or any agency thereof. The views and opinions of authors expressed herein do not necessarily state or reflect those of the United States Government or any agency thereof. 


\section{DISCLAIMER}

Portions of this document may be illegible in electronic image products. Images are produced from the best available original document. 


\title{
ANALYSIS OF FISSION PRODUCT BEHAVIOR IN THE SACLAY SPITFIRE LOOP TEST SSL-1
}

\author{
by \\ D. D. JENSEN, M. J. HAIRE,* and A. BALLAGNY**
}

Work supported in part under Contract EY-76-C-03-0167 Project Agreement No. 17 for the San Francisco Operations Office Department of Energy

* Present Address: Georgia Institute of Technology, Atlanta, Georgia ** Commissariat A L'Energie Atomique (CEA), Saclay, France

** Commissariat A L'Energie Atomique (CEA), Saclay, France, 
$\bullet$

$?$

in

• 


\section{FOREWORD}

The Saclay Spitfire Loop (SSL-1) test was carried out under a private cooperative program between the Commissariat a L'Energie Atomique (CEA) and General Atomic Company. Much of the information available from this test has not yet been made public. As such, some of the operational data used as input to the calculations are presented in summary form only. 
$\bullet$ 


\begin{abstract}
The behavior of the fission metal cesium and the fission gases krypton and xenon in the Saclay Spitfire Loop SSL-1 test has been compared to that predicted using General Atomic reference data and computer code models. This is the first in a series of analyses planned in order to provide quantitative validation of HTGR fission product design methods.

In this analysis, the first attempt to rigorously verify fission product design methods, the FIPERQ code was used to model the diffusion of cesium in graphite and release to the coolant stream. The comparisons showed that the cesium profile shape in the graphite web and the partition coefficient between fuel rod matrix material and fuel element graphite were correctly modeled, although the overall release was significantly underpredicted. Uncertainties in the source term (fissile particle failure fraction) and total release to the coolant precluded an accurate appraisal of the validity of FIPERQ. However, several recommendations are presented to improve the applicability of future in-pile test data for the validation of fission metal release codes.
\end{abstract}

The half-life dependence of fission gas release during irradiation was found to be in good agreement with the model used in the reference design materials, providing assurance that this aspect of the fission gas release predictions is properly modeled. 
$\bullet$ 
CONTENTS

FOREWORD . . . . . . . . . . . . . . . . . . . . . . . iii

ABSTRACT . . . . . . . . . . . . . . . . . . . v v

1. INTRODUCTION . . . . . . . . . . . . . . . . . . 1

2. FISSION PRODUCT TRANSPORT CODES . . . . . . . . . . . . . 3

2.1. FIPERQ/TRAFIC Codes . . . . . . . . . . . . 3

2.1.1. Transport Process ............. 4

2.1.2. FIPERQ Code .................. 9

2.1.3. TRAFIC Code .............. 10

2.2. Fission Gas Release Codes (RAD/RANDI) . . . . . . . . 11

3. DESCRIPTION OF SSL-1 LOOP EXPERTMENT . . . . . . . . . . . . . 14

3.1. Fuel Element Description . . . . . . . . . . . . 14

3.2. Plateout Sleeve Description . . . . . . . . . . 16

3.3. Primary Circuit Description . . . . . . . . . . 16

4. EXPERIMENTAL MEASUREMENTS . . . . . . . . . . . . . . 20

4.1. Preirradiation Measurements . . . . . . . . . . 20

4.1.1. Fuel Rod Fission Gas Release and Exposed Heavy Metal Contamination . . . . . . . . . . 20

4.1.2. Cesium Sorptivity in Graphite . . . . . . . . . 21

4.1.3. Cesium Diffusivity in Graphite . . . . . . . . 21

4.2. Operational Measurements . . . . . . . . . . . 23

4.2.1. Mean Operating Conditions . . . . . . . . 23

4.2.2. Fission Gas Release ............. 23

4.3. Postirradiation Examination (PIE) Measurements . . . . . . 27

4.3.1. Fuel Element PIE Measurements . . . . . . . . 27

4.3.2. Circuit Components PIE . . . . . . . . . 45

5. ANALYSIS OF DATA AND DESIGN METHODS VERIFICATION . . . . . . . 51

5.1. Fission Meta1 Release . . . . . . . . . . . . . 51

5.1.1. Source.................. 51

5.1.2. Fuel and Graphite Temperatures . . ...... . 55 
5.1.3. Integrated Fission Metal Release......... 55

5.1.4. Reference Input Data . . . . . . . . . 55

5.1.5. Results and Discussion........... 55

5.2. Fission Gas Release . . . . . . . . . . . . . 63

ACKNOWLEDGMENTS . . . . . . . . . . . . . . . . . . . 69

REFERENCES . . . . . . . . . . . . . . . . . . . . . . 70

APPENDIX A . . . . . . . . . . . . . . . . . . 73

FIGURES

2-1. Sequential steps in metallic fission product direct release

from the HTGR core . . . . . . . . . . . . . . 5

3-1. SSL-1 graphite fuel element . . . . . . . . . . . . 15

3-2. Schematic of Saclay Spitfire Loop SSL-1 . . . . . . . . . . 18

4-1. Fission gas release $(\mathrm{Kr}-85 \mathrm{~m})$ and calculated peak fuel temperatures during operation of SSL-1 loop test . . . . . . . 26

4-2. Fission gas release $(\mathrm{Kr}-85 \mathrm{~m})$ during the $\mathrm{SSL}-1$ loop test based on births in the fissile particles only . . . . . . . 29

4-3. Axial gross gamma scan for fuel rod stack C . . . . . . . 39

4-4. Normalized Cs/Zr ratio versus fuel rod layer for stacked SSL-1 fuel rods .. . . . . . . . . . . . . . . . 41

4-5. Axial sections from SSL-1 fuel element body . . . . . . . . 42

4-6. Axial profiles of Cs-134 (measured) and Cs-137 (calculated) in SSL-1 graphite fuel body . . . . . . . . . . . . . . . 44

4-7. Radial profiles of $\mathrm{Cs}-134$ and $\mathrm{Cs}-137$ in the graphite web adjacent to fuel rod stack $C 4$ in the SSL-1 loop test . . . . . 46

4-8. Axial profiles of $\mathrm{Cs}-134$ and $\mathrm{Cs}-137$ and calculated temperatures along the length of the "outer Inconel tube" of the SSL-1 loop test... . . . . . . . . . . . . 48

5-1. Predicted and measured Cs-137 loading in the SSL-1 fuel body.......................... 57

5-2. Cesium-137 profile in the graphite web at rod layer 4 of the SSL-1 test.................... 59

5-3. Plot of $\log (R / B)_{i}$ versus $\log \tau_{i} 1 / 2$ for krypton and xenon isotopes released from the SSL-1 fuel element at 25 EFPD . . . 64

5-4. Plot of $\log (R / B)_{i}$ versus $\log \tau_{i} 1 / 2$ for krypton and xenon isotopes released from the SSL-1 fuel element at 120 EFPD. . . 


\section{TABLES}

2-1. Comparison of differing input parameters for FIPERQ (SSL-1) and TRAFIC (reference) calculations .......... 12

3-1. Limiting test conditions for the SSL-1 loop test . . . . . . . 14

3-2. Summary description of coated particles irradiated in SSL-1 test . . . . . . . . . . . . . . . . . . 17

4-1. Sorption isotherm constants for cesium on SSL-1 matrix material and graphite used as input to FIPERQ . . . . . . . . 22

4-2. Mean operating conditions for the SSL-1 loop test . . . . . . 24

4-3. In-pile fractional releases of krypton and xenon isotopes from the SSL-1 loop . . . . . . . . . . . . . . 25

4-4. EOL $\mathrm{R} / \mathrm{B}(\mathrm{Kr}-85 \mathrm{~m}$ at $873 \mathrm{~K})$ for eighteen fuel rods from the SSL-1 loop test ................... 31

4-5. Time-dependent fraction of fissions in $\mathrm{U}-235$ and $\mathrm{U}-233$ in SSL-1 fissile and fertile particles . . . . . . . . . . 33

4-6. SSL-1 operational fuel particle failure data used as input to FIPERQ . . . . . . . . . . . . . . . . . . . . . . 34

4-7. Summary of cesium retention data for 100 particles irradiated in SSL-1 fuel rod C4 . . . . . . . . . . . . . 36

4-8. Summary of EOL fuel particle failure fractions determined from SSL-1 in-pile and PIE measurements . . . . . . . . 37

4-9. Summary of $\mathrm{Cs}-137$ release from the SSL-1 (mCi) . . . . . . . . 50

5-1. Comparison of predicted and measured $\mathrm{Cs}-137$ release from the SSL-1 loop . . . . . . . . . . . . . . . . . . 56

5-2. Summary of data on half-life dependence of $\mathrm{Kr}$ and $\mathrm{Xe}$ diffusion derived from the SSL-1 loop . . . . . . . . . . 


\section{INTRODUCTION}

The design and licensing of a High-Temperature Gas-Cooled Reactor (HTGR) is dependent in part upon rellable predictions of fission product behavior during steady-state and postulated accident conditions. It is important that the computer codes used to provide calculated fission product release and plateout be verified. This is done most convincingly by comparing the predicted and observed behavior of fission products in in-pile tests simulating reactor operating conditions (Ref. 1). The Saclay Spitfire Loop experiment SSL-1 is the first of a series of in-pile experiments that will be used to ensure the validity of HTGR fission product design methods.

Fission product migration studies to date have emphasized out-of-pile laboratory experiments designed to measure the effectiveness of each resistance or barrier to release from the fuel elements. Experiments have been reported describing fission product release from fuel particles (Refs. 2-8), diffusion through nuclear graphite (Refs. 2, 3, 9-12), and vaporization from graphite surfaces (Refs. 2, 3). These and other data have provided the bases for development of fission product transport models and codes. More recently the effectiveness of individual barriers to release has been evaluated during examinations of Peach Bottom reactor test and driver fuel elements (Refs. 9, 10, 13).

Through understanding obtained from studies of individual barriers, transport models have been formulated for each resistance and have been combined into a network of resistances which form the design models used to calculate fission product migration. Two concerns arise from this differential method of formulating design data and methods. First, without testing the total system of barriers, some pathway of fission product release into the coolant could be overlooked. Secondly, as a result of the uncertainty in the laboratory data, upper bounds to input data and transport mechanisms are frequently chosen which may result in significantly overpredicted radionuclide release from the HTGR core. 
Analysis of fission product transport in the SSL-1 loop focuses on the behavior of the fission metal cesium and the fission gases krypton and xenon. Cesium was selected for analysis because a large body of data was gathered on its behavior during the test program. A comparison of predicted and observed cesium release from the fuel element, together with corresponding uncertainty estimates, is presented to provide an estimate of the overall accuracy of the code calculations. The effectiveness of several barriers to metallic release is evaluated and compared to the predicted behavior obtained using reference design models. This work contributes to the validation of the metallic fission product transport codes FIPERQ (Ref. 14) and TRAFIC (Ref. 15). The half-life dependence of krypton and xenon diffusion in fuel rods has been evaluated using in-pile fission gas release data. This work contributes to the validation of the RAD and RANDI codes used to calculate fission product inventories in the HTGR core (Refs. 16-18). 


\section{FISSION PRODUCT TRANSPORT CODES}

\subsection{FIPERQ/TRAFIC CODES}

Data from the SSL-1 loop have been analyzed with the principal objective of verifying the FIPERQ code. The FIPERQ and TRAFIC codes, developed at General Atomic under the DOE Fuels and Core Development Program, are used to calculate the release of metallic fission products from the HTGR core. The models employed by these codes are mathematically equivalent. TRAFIC is a spectalized code designed to calculate total HTGR core metallic fission product release. FIPERQ is a more rigorous and flexible code with options for a variety of boundary conditions and geometries, and utilizes a more detailed printout of calculated release. Because of its greater adaptability, FIPERQ has been selected for use in modeling metal release from in-pile test loops. Both codes use the fundamental assumption that metallic fission product migration follows Fick's law of diffusion behavior.

Accurate predictions of cesium release from the HTGR core using FIPERQ and TRAFIC are important because Cs-137 has a long half-life (30.2 y), a high cumulative fission yield $(6.2 \%)$, and a daughter product $(\mathrm{Ba}-137 \mathrm{~m})$ with a hard gamma (105.7 fJ) emission. These characteristics combine to make Cs-137 a major contributor to the calculated gamma dose personnel may receive during maintenance operations. In addition, the DOE-sponsored Accident Initiation and Progression Analysis (AIPA) program quantified the uncertainties associated with fission product release calculations and confirmed that predicted cesium release is highly sensitive to the uncertainties present in the experimental data base (Ref. 19). These results highlighted the importance of verifying predicted metal release with in-pile test data. The SSL-1 test was selected for analysis because in-pile and PIE data were available on the release and plateout of both Cs-134 and Cs-137. Although knowledge of the behavior of other mobile fission metals ( $\mathrm{Sr}, \mathrm{Ba}, \mathrm{Rb}, \mathrm{Ce}, \mathrm{Eu}, \mathrm{Sm}$ ) in SSL-1 would have been useful, no data were gathered on these nuclides. Thus, this report summarizes the application of FIPERQ to cesium transport only. 
The transport model (as it existed in September 1977) and some of the more important assumptions used in the modeling are presented herein. Reference 15 discusses this topic at length. The direct release of metallic fission products is illustrated in the flow diagram of Fig. 2-1. Each of the sequential steps in the figure, from birth in the fuel to release into the coolant, can be envisioned as a resistance to release of fission products. As shown in the figure, the barriers can be segregated into three groups: barriers to release from fuel particles, from fuel rods, and from fuel blocks. Each step in the release process is briefly discussed in the following sections.

\subsubsection{Transport Process}

2.1.1.1. Release from Fuel Particles. The basic fuel configuration for the HTGR is the coated fuel particle, which consists of a spherical kernel of fissile and/or fertile material overcoated with multiple layers of coating material. The inner buffer coating is low-density pyrolytic carbon; the outer coatings are made of high-density, relatively impervious silicon carbide ( $\mathrm{SiC}$ ) and/or isotropic pyrocarbon (PyC).

The initial barrier to release is the fuel kernel. Most fission fragments are born in this region. These fission products can escape from the kernel in one of two ways: recoil or diffusion. Since kernel diameters (200 to $500 \mu \mathrm{m}$ ) are large compared with the recoil range (about $6 \mu \mathrm{m}$ for $\mathrm{Cs}-137$ ), the vast majority of fission fragments do not escape directly from the kernel via recoil; they must be released to the coating by diffusion (Refs. 20, 21).

The second barrier to metallic fission product release is diffusion through particle coatings. This barrier, shown schematically as a single block in Fig. 2-1, is actually several resistances in series, one for each coating. In TRISO coated fuel particles (PyC, SiC, PyC), the silicon carbide coating is a particularly effective barrier to release. This coating is sufficiently retentive that no cesium (or any other) fission product is released at normal operating temperatures. For particles with failed coatings, the reference design assumption is that $100 \%$ of the cesium inventory is released from carbide kernels upon coating failure, while cesium release from oxide kernels is dependent upon irradiation temperatures. 


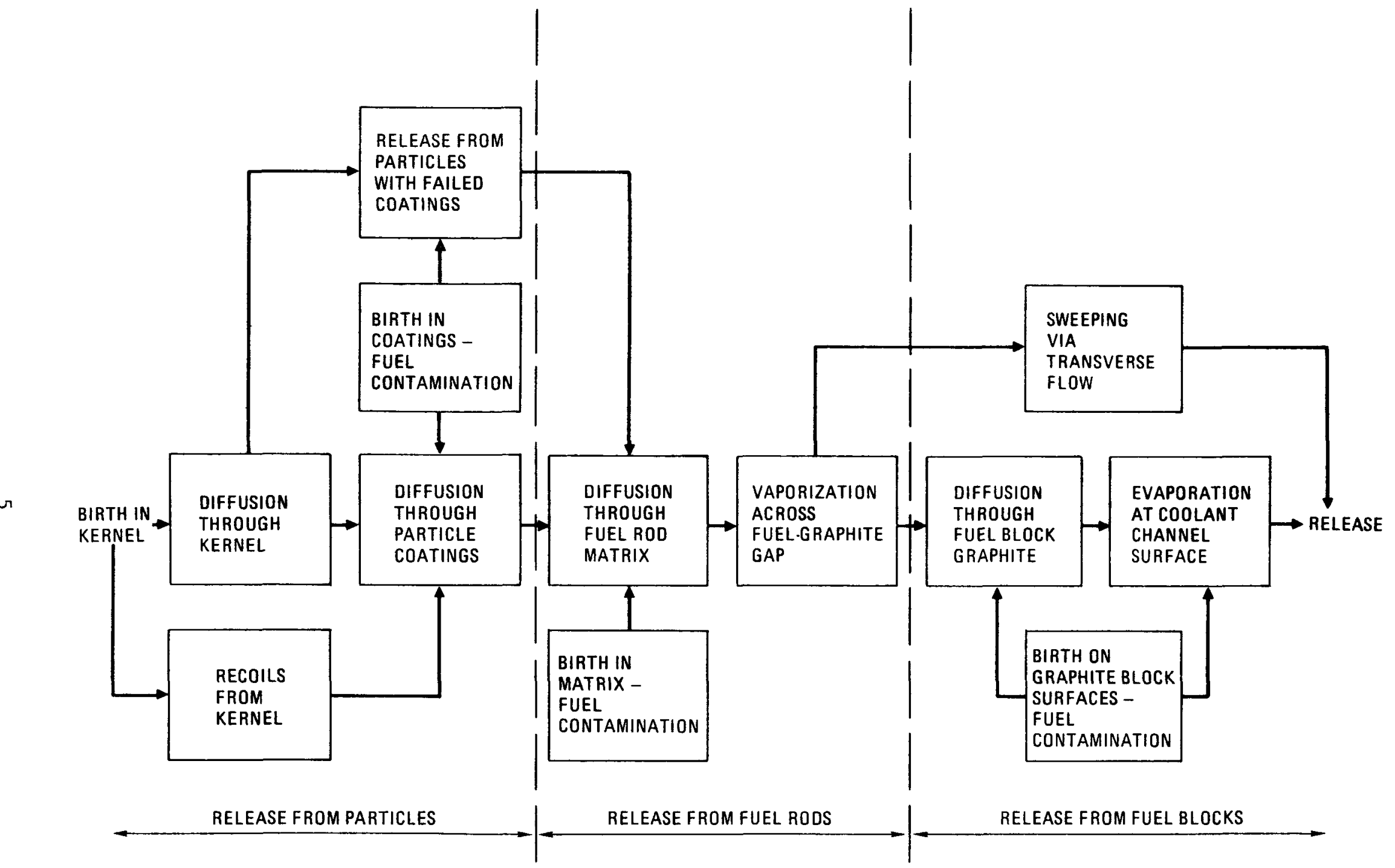

Fig. 2-1. Sequential steps in metallic fission product direct release from the HTGR core 
2.1.1.2. Release From Fuel Rods. Coated fuel particles are blended with a bonding matrix of carbonaceous material and formed into rods. The fuel rod matrix material, composed of a mixture of pitch coke and graphite filler, is highly sorptive of metallic fission product atoms and serves as another barrier to release. The residual coke of the fuel rod binding pitch is the active component in the matrix upon which most of the metallic fission product sorption takes place.

After release from failed fuel particles, metallic fission product atoms migrate through the matrix to the surface of the fuel rod. The reference design includes the assumption that diffusion of fission product atoms in the matrix material is rapid compared with diffusion in graphite. In practice this is modeled by arbitrarily choosing a fuel rod matrix diffusion coefficient at least two orders of magnitude larger than that utilized to model diffusion in graphite.

The sorption of metallic fission products by matrix material and by fuel element graphite is described by sorption isotherms. These are empirical equations that relate the vapor pressure, $p(\mathrm{~Pa})$, and the solid phase fission metal concentration, $C$ (mmol/ $\mathrm{kg}$ sorbent), in equilibrium at a He-graphite interface. Within the higher concentration range, the sorption of metallic fission products is described by the Freundlich isotherm in the following form:

$$
\ln p=(A+B / T)+(D+E / T) \ln C,
$$

where A, B, D, and $E$ are constants determined by the fit of Eq. 2-1 to experimental data. Freundlich sorption is characterized by an increase in the heat of adsorption of the sorbed metal with decreasing concentration. However, the magnitude of the heat of adsorption must reach an upper limit at some low concentration. Such a limit is consistent with observations in the cesium-graphite system, where a transition from Freundich to Henrian behavior has been observed (Ref. 22). The Henrian 1sotherm is characterized by 
a constant heat of adsorption and by a direct proportionality between the vapor pressure and the concentration of sorbed metal:

$$
\ln p=(A+B / T)+(D-1+E / T) \ln C_{t}+\ln C,
$$

where $C_{t}$ is the concentration at which the transition from Freundlich to Henrian behavior occurs and A, B, D, and E are the same as in Eq. 2-1.

The vapor pressure of a given fission product isotope over a graphite surface can be governed not only by the concentration of that isotope at the graphite surface, but also by the concentration of the other isotopes of the element of interest, the atoms of which are competing for sorption sites at the surface. Likewise, the isotopes of other elements can compete for those sites. The ultimate result of this competition for sorption sites is that the vapor pressure of the isotope of interest in the fuel rod - graphite gap (and at the coolant hole surface) can be higher than it would be if only the single isotope of interest were being sorbed on the surface. This effect sometimes results in slightly higher fission product release.

For a given metal partial pressure at a given temperature, the equilibrium concentration of a fission metal in the fuel rod matrix material has generally been found to be greater than the concentration in the graphite. The ratio of surface concentrations of a metallic fission product element at the interface between the two materials is referred to as the sorption ratio or the partition factor, $\phi$. Hence,

$$
\phi=\frac{\text { surface concentration of metal in matrix }}{\text { surface concentration of metal in graphite }} \text {, }
$$

where $\phi$ is defined under isothermal conditions (i.e., the fuel rod surface and graphite fuel hole surface are taken at the same temperature), and a unfform metallic partial pressure is assumed to exist in the fuel rod graphite web gap.

Under ideal isothermal conditions, an increase in the concentration of a metallic fission product species in the matrix results in an increase in 
the vapor pressure in the gap; simultaneously, the concentration at the fuel hole surface increases, thereby maintaining the proper sorption ratio. In actual operation a temperature gradient exists across the gap. This temperature gradient, the magnitude of which depends on the reactor operating conditions, affects the concentration at the fuel hole surface and hence affects the sorption ratio given in Eq. 2-3. Thus a specific sorption ratio must be obtained for each reactor operating condition. This factor is taken into account in the sorption ratio calculation in HTGR design.

2.1.1.3. Release from Fuel Blocks. Fuel rods are placed in the fuel holes of hexagonal nuclear-grade graphite blocks to form the fuel element assembly. Although generally less sorptive of metallic fission products than fuel rod matrix material, fuel block graphite does serve as an additional sorptive barrier to release. (An increase in the sorptivity of some metallic species on graphite under fast neutron irradiation has been observed (Ref. 3) but is ignored in current HTGR design calculations.)

Fission products introduced at the fuel hole surface must migrate across the graphite web to the coolant hole surface where they may be released. The dominant transport mechanism controlling migration in the graphite web is assumed to be diffusion in a concentration gradient. Metallic fission product transport is a complicated multicomponent phenomenon. It probably includes the bulk diffusion in grains, surface diffusion along grain surfaces, and transport in the gas phase of pores. Simplifying assumptions are made to describe the process. It is assumed that diffusion is described by Fick's first law:

$$
J_{i}(r, t)=-D_{i}(r, t) \nabla C_{i}(r, t),
$$

$$
\text { where } \begin{aligned}
J_{i}(r, t) & =\text { diffusion flux of species } i\left(\mathrm{~kg} / \mathrm{m}^{2}-\mathrm{s}\right), \\
\nabla C_{i}(r, t) & =\text { concentration gradient of species } i\left(\mathrm{~kg} / \mathrm{m}^{4}\right), \\
D_{i}(r, t) & =\text { "effective" diffusion coefficient of species } i\left(\mathrm{~m}^{2} / \mathrm{s}\right) .
\end{aligned}
$$

The "effective" diffusion coefficient is that coefficient which, in terms of Fick's law, describes on a macroscopic scale the various microscopic diffusion 
phenomena which occur in the fuel material, each of which is characterized by its own diffusion coefficient. The diffusion coeffictent in the graphite web, as well as in the fuel rod matrix, varies with temperature according to:

$$
D=D_{0} \exp (-Q / R T)
$$

$$
\text { where } \begin{aligned}
\mathrm{D}_{\mathrm{O}} & =\text { preexponential constant }\left(\mathrm{m}^{2} / \mathrm{s}\right), \\
\mathrm{Q} & =\text { activation energy }(\mathrm{J} / \mathrm{mol}), \\
\mathrm{R} & =\text { gas constant }(8.314 \mathrm{~J} / \mathrm{mo} 1-\mathrm{K}), \\
\mathrm{T} & =\text { temperature }(\mathrm{K}) .
\end{aligned}
$$

Upon reaching the coolant hole wall, the metallic fission product atoms can escape to the coolant by evaporation into the flowing helium. The mass flux of metallic fission product atoms at the coolant hole surface, $J_{L}$, is determined by the relationship

$$
J_{L}=h\left(C_{g}-C_{H e}\right),
$$

where $h$ is the convective mass transfer coefficient $(\mathrm{m} / \mathrm{s})$ dependent on the diffusivity of the metallic species in helium. The driving force for this process is the difference in concentration of the fission product in the coolant adjacent to the coolant hole surface, $\mathrm{C}_{\mathrm{g}}\left(\mathrm{mol} / \mathrm{m}^{3}\right)$, and in the coolant free stream, $\mathrm{C}_{\mathrm{He}}\left(\mathrm{mol} / \mathrm{m}^{3}\right)$. In practice the free stream concentration in the coolant is assumed to be zero.

\subsubsection{FIPERQ Code}

The fundamental transport equation solved by FIPERQ (and TRAFIC) is:

$$
\begin{gathered}
\frac{\partial C_{i}(\vec{r}, t)}{\partial t}=S_{i}(\vec{r}, t)-\lambda_{i} C_{i}(\vec{r}, t)-\vec{\nabla} \cdot \vec{J}_{i}(\vec{r}, t) \\
i=1,2,3, \ldots, I,
\end{gathered}
$$


where $C_{i}(\vec{r}, t)=$ volume concentration of the $i^{\text {th }}$ diffusing species $\left(\mathrm{mol} / \mathrm{m}^{3}\right)$, $S_{i}(\vec{r}, t)=$ volumetric source of the $i^{\text {th }}$ diffusing species $\left(\mathrm{mol} / \mathrm{m}^{3}-\mathrm{s}\right)$, $\lambda_{1}=$ radioactive decay constant for the $i^{\text {th }}$ species $\left(s^{-1}\right)$.

As noted in Section 2.1.1, the diffusion process is assumed to be described by the classical Fick's law model. Equation 2-7 is solved in onedimensional slab, cylindrical, or spherical geometry using mixed inhomogeneous boundary conditions to describe the transport of metallic fission products.

At the fuel rod - graphite web interface, a change in the physical properties of the transport medium occurs; the condition is imposed that the concentration $C_{i}^{-}\left(r_{c}, t\right)$ just to the left of the interface is equal to some factor times the concentration $c_{i}^{+}\left(r_{c}, t\right)$ just to the right of the interface; 1.e.,

$$
C_{i}^{-}\left(r_{c}, t\right)=\phi_{1}\left(r_{c}\right) c_{i}^{+}\left(r_{c}, t\right)
$$

where $\phi_{1}\left(r_{c}\right)$ is the partition factor described by Eq. 2-3 corrected for the different temperatures in the matrix and graphite. In addition, the diffusion current across an interface is continuous; i.e.,

$$
J_{i}^{-}\left(r_{c}, t\right)=J_{i}^{+}\left(r_{c}, t\right)
$$

FIPERQ uses a finite difference scheme to solve Eq. 2-7 by an iterative method to obtain predictions of metal loading in matrix material, $\phi$, metal loading in graphite, and total metal release to the coolant.

\subsubsection{TRAFIC Code}

The TRAFIC code is capable of rapid computation of metallic fission product release at a great many spatial positions in the HTGR core. The need for such a code, as opposed to the more rigorous FIPERQ solution, is due to the fact that release is a highly nonlinear function of temperature and temperature history. Temperatures vary in an irregular manner with space and 
time in the HTGR core, and a great many space points must be sampled in order to integrate the results and provide total release (Ref. 15). Table 2-1 provides a comparison of differing input parameters used for FIPERQ and TRAFIC calculations.

\subsection{FISSION GAS RELEASE CODES (RAD/RANDI)}

The RAD and RANDI codes are used to estimate fission product inventories within the HTGR system (Refs. 16, 17). These codes estimate the fission product nuclide inventories in the fuel elements, in the primary coolant, and on the surfaces exposed to the primary coolant. RAD utilizes a general decay scheme allowing decay from any number of nuclides with branching from parent and grandparent radionuclides. RANDI incorporates a more sophisticated model of radionuclide decay and a more comprehensive analysis of fission product behavior in the HTGR primary circuit.

The most important variable used by the RAD and RANDI codes is the steady-state fractional release of each isotope from the fuel element, $(R / B)_{i}$. The release-to-birth ratio is primarily dependent on the fission element, radioactive half-life, condition of the coating (intact or failed), and fuel element temperature. The fractional release is determined from in-pile experiments on as-manufactured fuel rods and fuel particles with failed coatings dispersed in fuel rods. From these measurements, diffusion parameters are calculated which are used as input to the codes.

Data from SSL-1 are suitable for use in verifying the assumed half-life of fission gas release. Values of $(R / B)_{j i}$ are calculated using the expression

$$
(R / B)_{j i}=3\left(\frac{\xi_{j}}{\lambda_{i}}\right)^{1 / 2}\left[\operatorname{coth}\left(\frac{\lambda_{i}}{\xi_{j}}\right)^{1 / 2}-\left(\frac{\xi_{i}}{\lambda_{i}}\right)^{1 / 2}\right] \text {, }
$$

where $(R / B)_{j i}=$ fractional release from either as-manufactured fuel or fuel fuel with falled fuel particle coatings (the latter case applies to SSL-1), 
TABLE 2-1

COMPARISON OF DIFFERING INPUT PARAMETERS FOR FIPERQ (SSL-1) AND TRAFIC (REFERENCE) CALCULATIONS

\begin{tabular}{|c|c|c|}
\hline Variable & FIPERQ $(S S L-1)$ & TRAFIC (Reference) \\
\hline Fission power & $\begin{array}{l}\text { Derived from (1) heat balance in loop, } \\
\text { and (2) EOL burnup measurements }\end{array}$ & Input from physics codes \\
\hline Temperatures & $\begin{array}{l}\text { Calculated using in-pile thermocouple } \\
\text { temperature measurements }\end{array}$ & Input from thermal codes \\
\hline Particle failure fractions & $\begin{array}{l}\text { Obtained from (1) in-pile and PIE } \\
\text { measurements of } \mathrm{R} / \mathrm{B}(\mathrm{Kr}-85 \mathrm{~m}) \text { and } \\
\text { (2) metallographic examinations }\end{array}$ & $\begin{array}{l}\text { Input from fuel performance } \\
\text { codes }\end{array}$ \\
\hline $\begin{array}{l}\text { Cesium release from } \\
\text { particles }\end{array}$ & $\begin{array}{l}\text { (1) No release from intact TRISO } \\
\text { particles and ( } 2 \text { ) empirical estimate } \\
\text { of release from failed TRISO particles }\end{array}$ & $\begin{array}{l}\text { (1) No release from intact } \\
\text { TRISO particles, diffusive } \\
\text { release from intact BISo } \\
\text { particles and (2) total } \\
\text { release from failed BISO } \\
\text { and TRISO particles }\end{array}$ \\
\hline Effect of multiple species & $\begin{array}{l}\text { Multiple species effect calculated by } \\
\text { code }\end{array}$ & $\begin{array}{l}\text { Correction factor derived } \\
\text { from FIPERQ applied to } \\
\text { calculated release }\end{array}$ \\
\hline
\end{tabular}




$$
\begin{aligned}
& \xi_{j}=\text { diffusion parameter for chemical element } j\left(s^{-1}\right), \\
& \lambda_{i}=\text { decay constant for isotope } i \text { of element } j\left(s^{-1}\right)
\end{aligned}
$$

For release fractions less than 0.1 (sma11 values of $\xi / \lambda$ ), Eq. 2-10 reduces to

$$
(R / B)_{j i} \approx 3 \sqrt{\frac{\xi_{j}}{\lambda_{i}}} .
$$

Equation 2-10 has been derived and discussed by several authors (Refs. 16, 23, 24). This equation is the steady-state solution of the diffusion equation in sperical coordinates assuming (1) constant birth rate and (2) zero concentration at the surface of a sphere. The diffusion parameter, $\xi_{j}$, is defined as $\xi_{j}=D_{j} / a^{2}$, where $D_{j}$ is a diffusion coefficient with dimensions of $\mathrm{m}^{2} / \mathrm{s}$, characterizing release of noble gas from the fuel element, and where $a$ is a characteristic distance through which the fission products diffuse in escaping from the fuel. The values of $D_{j}$ and a are not used directly in design analyses. Rather, fractional release is determined from in-pile measurements. This $R / B$ value is then substituted into $\mathrm{Eq}$. 2-10, from which the diffusion parameter, $\xi_{j}$, is calculated. The value of $\xi_{j}$ is then used as input data to the codes.

From Eq. 2-11, it can be seen that fractional gaseous releases are proportional to the square-root of isotope half-life. The fractional releases of five krypton isotopes and six xenon isotopes released from SSL-1 fuel have been used to verify the half-1ife assumption used in design calculations. 


\section{DESCRIPTION OF SSL-1 LOOP EXPERIMENT}

The Saclay Spitfire Loop test SSL-1 was one of a series of experiments carried out by the Commissariat a l'Energie Atomique (CEA) to verify the irradiation performance of candidate HTGR fuel materials and graphite. Specifically, SSL-1 was designed to test the irradiation behavior of (1) General Atomic (GA) manufactured fuel rods containing TRISO coated (8Th,U) $\mathrm{O}_{2}$ fissile particles and TRISO coated $\mathrm{ThO}_{2}$ fertile particles, and (2) Pechiney $P_{3}$ JHAN fuel element graphite. A secondary objective of these tests was to provide information for subsequent verification of fission product transport codes.

Irradiation of the SSL-1 fuel element was carried out in the Spitfire loop located in the Osiris reactor at Saclay, France. Irradiation took place between December 3, 1973 and May 28, 1974 and was terminated after 120 equivalent full-power days (EFPD) of operation. The limiting test conditions are presented in Table 3-1.

TABLE 3-1

LIMITING TEST CONDITIONS FOR THE SSL- 1 LOOP TEST

\begin{tabular}{l|l}
\hline $\begin{array}{l}\text { Peak fast fluence }(E>29 \mathrm{fJ}) \\
\quad(\mathrm{E}>0.18 \mathrm{MeV})\end{array}$ & $5.0( \pm 1.0) \times 10^{25} \mathrm{n} / \mathrm{m}^{2}$ \\
Peak fuel particle burnups & $7.3( \pm 1.3) \%$ FIMA $(8 \mathrm{Th}, U) 0_{2}$ fissile particles \\
& $0.9( \pm 0.2) \%$ FIMA Th0 ${ }_{2}$ fertile particles \\
Maximum linear fuel rod & $6.6( \pm 1.2) \mathrm{W} / \mathrm{mm}$ \\
$\quad$ power rating & $1520( \pm 40) \mathrm{K}$ \\
$\begin{array}{l}\text { Maximum fuel temperature } \\
\text { Average helium coolant } \\
\text { pressure }\end{array}$ & $6.1( \pm 0.2) \mathrm{MPa}[60( \pm 2) \mathrm{atm}]$ \\
\hline
\end{tabular}

3.1. FUEL ELEMENT DESCRIPTION

The SSL-1 fuel element (Fig. 3-1) was designed to represent a geometric unit cell of an HTGR fuel element. The fuel body was machined by the CEA 

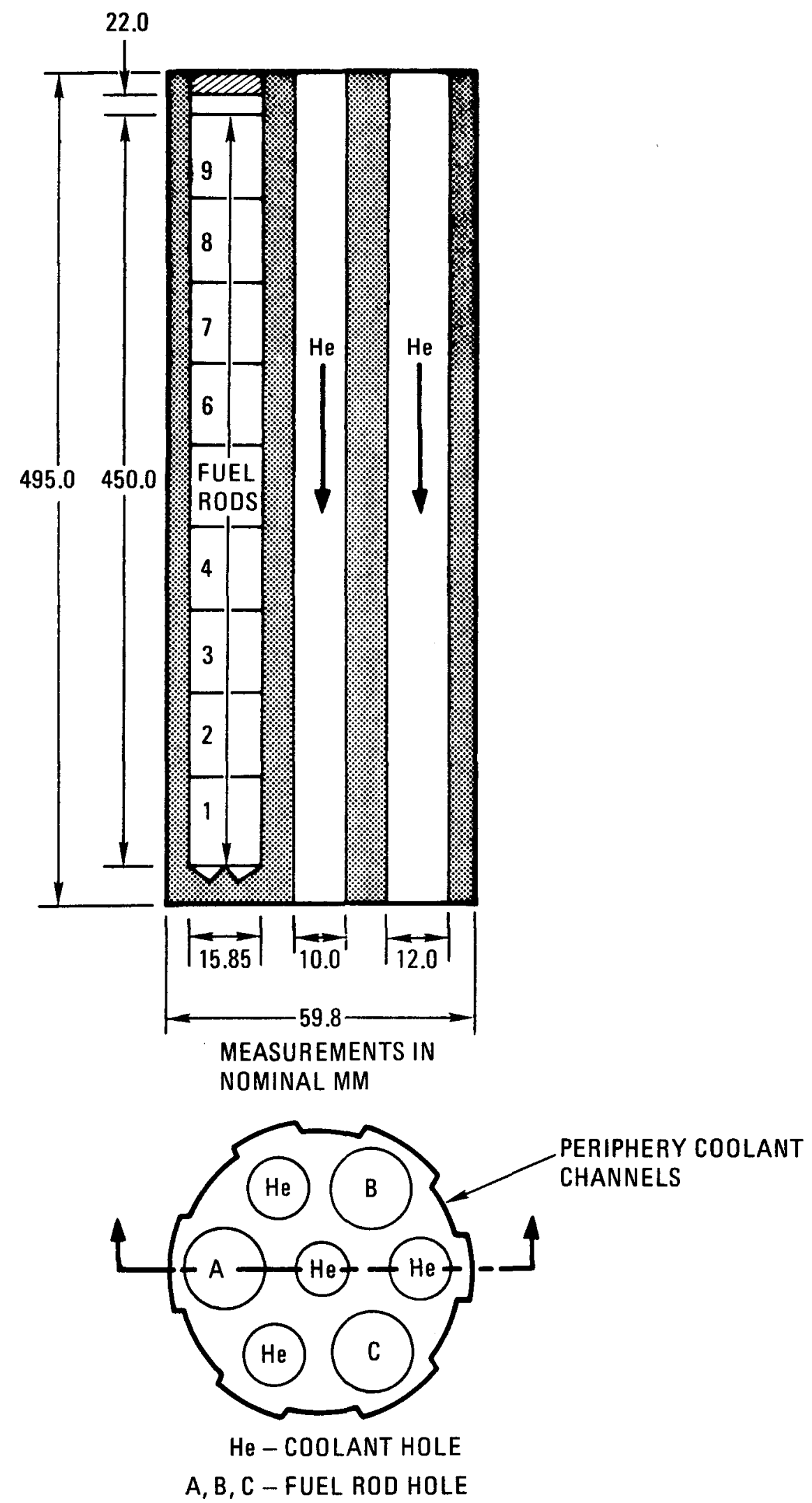

Fig. 3-1. SSL-1 graphite fuel element 
from Pechiney $P_{3}$ JHAN graphite; the 27 fuel rods were manufactured by GA. Nine green fuel rods (representing one of three fuel rod stacks in the element, i.e., stack $A$ ) were carbonized in $\mathrm{Al}_{2} \mathrm{O}_{3}$ by the cure-in-bed technique; these rods were fitted into the fuel body after the remaining 18 green fuel rods (stacks $\mathrm{B}$ and $\mathrm{C}$ ), comprising the two remaining fuel rod stacks, were carbonized in the fuel block by the HTGR reference cure-in-place method. Table 3-2 provides a summary description of coated particles irradiated in SSL -1 .

\subsection{PLATEOUT SLEEVE DESCRIPTION}

Two graphite plateout sleeves were installed in the circuit downstream of the fuel element. These sleeves were designed to sorb a portion of the metallic fission products released from the fuel during irradiation. The structures consisted of two concentric graphite rings with the following characteristics:

$\begin{array}{ll}\text { Length of rings } & 400 \mathrm{~mm} \\ \text { Radial gap between rings } & 4.0 \mathrm{~mm} \\ \text { Thickness of rings } & 5.0 \mathrm{~mm} \\ \text { Inner ring diameter } & 8.0 \mathrm{~mm} \text { I.D. } \\ \text { Outer ring diameter } & 6.0 \mathrm{~mm} \mathrm{I.D.}\end{array}$

\subsection{PRIMARY CIRCUIT DESCRIPTION}

The important features of the circuit, including the fuel element and plateout sleeves, are shown in Fig. 3-2. The in-pile section of the circuit included:

1. A double pressure casing which allowed the exchange of heat between the hot helium leaving the fuel element and the water moderator coolant. This design permitted regulation of the fuel element temperature by variation of the conductance of the gas in the gap between Hastelloy tubes (the gas was a variable mixture of helium and nitrogen). 
TABLE 3-2

SUMMARY DESCRIPTION OF COATED PARTICLES IRRADIATED IN SSL- 1 TEST

\begin{tabular}{|c|c|c|c|c|c|c|c|c|c|c|c|c|c|c|c|c|c|c|c|c|c|c|c|}
\hline \multirow[b]{3}{*}{$\begin{array}{l}\text { Data Retrieval } \\
\text { Number }\end{array}$} & \multirow[b]{3}{*}{ Fuel Type } & \multirow{2}{*}{\multicolumn{2}{|c|}{ Kerne 1}} & \multicolumn{13}{|c|}{ Coatings } & \multicolumn{7}{|c|}{ Total Coated Particle } \\
\hline & & & & & \multicolumn{2}{|c|}{ Buffer } & \multicolumn{3}{|c|}{ Inner Isotropic PyC } & \multicolumn{2}{|c|}{ sic } & \multicolumn{4}{|c|}{ Outer Isotropic PyC } & \multirow{2}{*}{$\begin{array}{c}\text { Total }(c) \\
\text { Coat } \begin{array}{c}(\mathrm{c} n \\
\text { Thickness } \\
(\mu \mathrm{m})\end{array} \\
\end{array}$} & \multirow[b]{2}{*}{$\begin{array}{c}\text { Mean } \\
\text { Dalaneter } \\
(\mathrm{mm})\end{array}$} & \multirow[b]{2}{*}{$\begin{array}{l}\text { Density } \\
\left(\mathrm{g} / \mathrm{cm} \mathrm{m}^{3}\right)\end{array}$} & \multicolumn{2}{|c|}{ Metal Loading } & \multirow{2}{*}{$\begin{array}{l}\text { Fission Gas } \\
\text { Release }(d)\end{array}$} & \multicolumn{2}{|c|}{ Surface contem ination ${ }^{(e)}$} \\
\hline & & Type & $\begin{array}{c}\text { Mean } \\
\text { Dianet ter } \\
(\text { Lim) }\end{array}$ & $L^{\text {type }}{ }^{\text {(a) }}$ & $\begin{array}{c}\text { Thick- } \\
\text { ness } \\
\text { (um) }\end{array}$ & 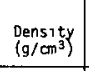 & $\begin{array}{c}\text { Thick- } \\
\text { ness } \\
\text { (um) }\end{array}$ & \begin{tabular}{|l} 
Density \\
$\left(1 / / \mathrm{cm}^{3}\right)^{\prime}$
\end{tabular} & OPTAF $^{(b)}$ & $\begin{array}{c}\text { Thick- } \\
\text { ness } \\
\text { (sm) } \\
\end{array}$ & \begin{tabular}{|l} 
Denstity \\
$\left(i / g \pi^{3}\right)$
\end{tabular} & $\begin{array}{c}\text { Thick- } \\
\text { ness } \\
\text { (um) }\end{array}$ & \begin{tabular}{|l} 
Density \\
$\left(g / \mathrm{cm}^{3}\right)$
\end{tabular} & $\begin{array}{l}\text { Coating } \\
\text { Rate } \\
\text { (nm/minn }) \\
\end{array}$ & OPTAF & & & & $\begin{array}{c}U \\
(w t *) \\
\end{array}$ & $\begin{array}{c}\text { Th } \\
\text { (wt g) }\end{array}$ & & \begin{tabular}{c|} 
\\
$(g \mathrm{~V} / \mathrm{g} U)$
\end{tabular} & $\frac{T h}{(g T h / g T h)}$ \\
\hline $6155-01-010$ & Fissile $\mathrm{f}^{(f)}$ & $(8 \mathrm{Th}, \mathrm{U}) \mathrm{O}_{2}$ & 512 & TRISO & 100 & 1.22 & 30 & 1.96 & 1.20 & 27 & 3.22 & 40 & 1.78 & 3.08 & 1.13 & 191 & 888 & 3.32 & 5.7 & 42.8 & $1 \times 10^{-6}$ & $7 \times 10^{-7}$ & $<10^{-7}$ \\
\hline $6155-01-020$ & Fissile $^{(f)}$ & $(8 \mathrm{rh}, \mathrm{U}) \mathrm{O}_{2}$ & 502 & TRISO & 106 & 1.24 & 32 & 1.93 & 1.17 & 34 & 3.22 & 42 & 1.81 & 3.36 & 1.07 & 194 & 885 & 3.34 & 5.2 & 43.6 & $6 \times 10^{-7}$ & $6 \times 10^{-7}$ & $<10^{-7}$ \\
\hline $6155-07-030(9)$ & Fissile ${ }^{(f)}$ & $(8 \mathrm{Th}, \mathrm{U}) \mathrm{O}_{2}$ & 506 & TRISO & ${ }_{103}(\mathrm{~h})$ & $1.23^{(h)}$ & $31^{(\mathbf{h})}$ & $1.94^{(h)}$ & 1.24 & 27 & 3.21 & 40 & 1.79 & (1) & 1.11 & 190 & 884 & 3.33 & 5.3 & 42.6 & $2 \times 10^{-7}$ & $=10^{-7}$ & $3 \times 10^{-6}$ \\
\hline $6252-00-020$ & Fertile & $\mathrm{ThO}_{2}$ & 512 & TRISO & 60 & 1.16 & 30 & 1.87 & 3.25 & 31 & 3.21 & 42 & 1.81 & 4.24 & 1.24 & 164 & 833 & 3.77 & (1) & 54.0 & (i) & (i) & $<10^{-7}$ \\
\hline $6351-01-020$ & Inert & c & $210-297^{(j)}$ & TRISO & (t) & (1) & 29 & 1.76 & 109 & 29 & 3.22 & 36 & 8.75 & 1.06 & 1.12 & (1) & 573 & 1.83 & (1) & (j) & (1) & (1) & (i) \\
\hline
\end{tabular}

(a) TRIso denotes a coating design with a sic layer

(b) optical Anisotropy Factor, relative unit

(c) Sum of buffer + inner isotropic, Sic. and outer-15otropic coating thickness measurements

$1100^{\circ} \mathrm{C}$

(f) $93.29 \%$ enriched uranium

(9) Batch 6155-01-030 is a composite of 6155-01-010 and 6155-01-020 (equal we ights of each)

(h) Estimated by averaging the values of the individual batches

(1) Not determined

(j) Determined by a sieve analysis 


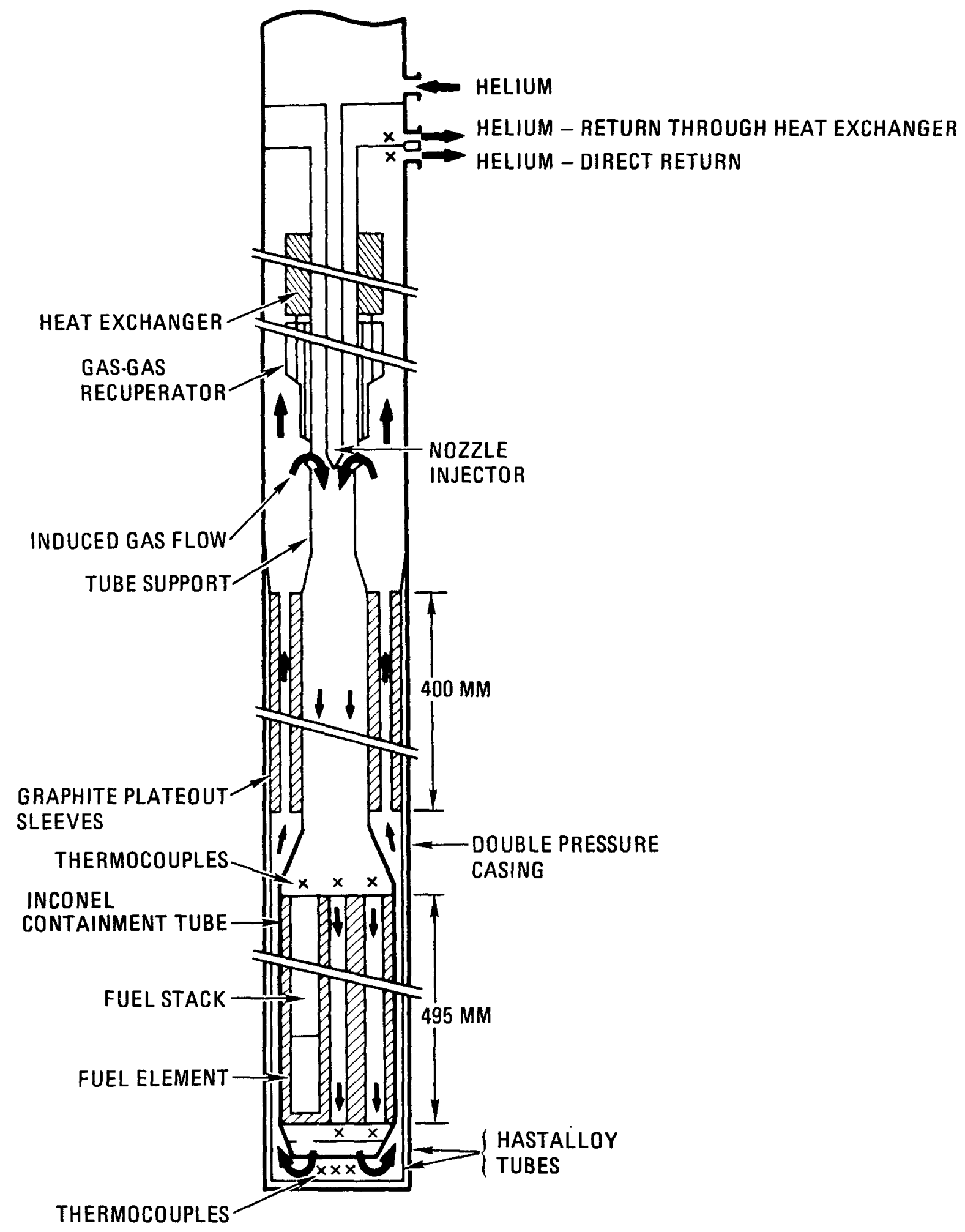

Fig. 3-2. Schematic of Saclay Spitfire Loop SSL-1 
2. A fuel element tube support which included the outlet gas - inlet gas recuperator (see below), blological shielding, and nozzle injector. The tube support was equipped with thermocouples to measure helium temperatures in the nozzle, at the level of the induced coolant flow circuit, at the exit of the fuel element, and in the cold section of the recuperator.

3. An outlet gas - inlet gas recuperator which consisted of cylindrical tubes in a concentric configuration on the outside of the tube support. This arrangement served to raise the temperature of the cool inlet gas to the desired operating level.

The out-of-pile section of the loop consisted of several components including the helium purification system, on-line gas analysis instrumentation, helium coolant impurity injection circuit, and monitoring devices for recording the activity level of gaseous fission products. 


\section{EXPERTMENTAL MEASUREMENTS}

\section{1. PREIRRADIATION MEASUREMENTS}

The fuel and graphite utilized in SSL-1 were characterized prior to irradiation. Preirradiation measurements of importance for cesium release calculations included fuel rod fission gas release, as-manufactured exposed heavy metal, and diffusivity and sorption of cesium in graphite.

\subsubsection{Fuel Rod Fission Gas Release and Exposed Heavy Metal Contamination}

The release of $\mathrm{Kr}-85 \mathrm{~m}$ from the GA fuel rods prepared by the packed-bed and cure-in-place techniques was measured prior to irradiation.* All rods revealed an $R / B \leq 4.0 \times 10^{-6}(1373 \mathrm{~K})$. This low level of release was attributed to high preirradiation fissile particle integrity and low levels of uranium contamination in the particle coatings and fuel rod matrix material. In addition, hydrolysis test** results from eight sister rods revealed low levels of exposed heavy metal contamination $\left(\leq 2 \times 10^{-6}\right)$ in all but one $\operatorname{rod}\left(1 \times 10^{-3}\right)$; burn leach test*** results confirmed the acceptable level of particles with failed SiC coatings $\left(\leq 6 \times 10^{-3}\right)$.

$*_{\mathrm{R}} / \mathrm{B}$ measurements for the cure-in-place rods were carried out on fuel rods pressed out of a sister fuel block prepared and cured in an identical manner to the fuel element irradiated in SSL-1.

**The hydrolysis test is used to measure exposed heavy metal contamination. Selected fuel rods are heated to $2073 \mathrm{~K}$ in a reducing atmosphere to convert exposed heavy metal oxides to carbides. The rods are then placed in a pressure vessel and exposed to steam; the quantity of ethane released following carbide hydrolysis to oxide is measured with a gas chromatograph. This quantity is directly relatable to exposed uranium and thorium in particles with falled coatings and in matrix material.

***The burn-leach test is used to measure the fraction of TRISO coated

particles with failed SIC coatings. Fuel rods are exposed to air at $21073 \mathrm{~K}$ in order to bring about complete oxidation of the matrix material and outer pyrocarbon coatings on the particles. The residue is then dissolved in acid and the resulting solution is lightly irradiated. The solutions are gamma counted and the quantity of heavy metals in particles with failed SiC coatings is measured. 


\subsubsection{Cesium Sorptivity in Graphite}

The sorption isotherms of cesium on GA reference matrix material and Pechiney $P_{3}$ JHAN graphite (Ref. 3) were measured at GA. The results, shown in Table 4-1, were input into Egs. $2-1$ and 2-2 and utilized as input to FIPERQ calculations. The results for $P_{3}$ JHAN graphite indicate that this graphite and GA reference $\mathrm{H}-451$ graphite have similar cesium sorption characteristics. (Although the isotherms are presented with a temperaturedependent $C_{t}$ expression, this was not used as FIPERQ input as the code currently can accept only a single value. The calculated values of $C_{t}$ at $1273 \mathrm{~K}$, shown in Table 4-1, were used as input.)

\subsubsection{Cesium Diffusivity in Graphite}

The out-of-pile diffusivity of cesium in $\mathrm{P}_{3}$ JHAN was measured at GA prior to irradiation. The diffusion behavior was found to be very similar to that of cesium in H-451 graphite. Because of this, the reference GA diffusivity expression derived principally from concentration profile measurements was used to model cesium diffusion in the fuel element (Ref. 3 ):

$$
D=D_{0} \exp (-Q / R T)
$$

$$
\text { where } \begin{aligned}
D & =\text { diffusion coefficient }\left(\mathrm{m}^{2} / \mathrm{s}\right), \\
D_{O} & =9.64 \times 10^{-7} \mathrm{~m}^{2} / \mathrm{s}, \\
Q & =143,700(\mathrm{~J} / \mathrm{mol}) \\
R & =8.314 \mathrm{~J} / \mathrm{mol}-\mathrm{K}, \\
T & =\text { temperature }(\mathrm{K}) .
\end{aligned}
$$

Selection of the diffusivity expression is important since parametric studies carried out with FIPERQ have shown that predicted release for short duration tests is highly sensitive to the input value of $D$ (Ref. 19). 
TABLE 4-1

SORPTION ISOTHERM CONSTANTS FOR CESIUM ON SSL-1 MATRIX MATERIAL AND GRAPHITE USED AS INPUT TO FIPERQ(a)

\begin{tabular}{l|l|l|c|c|c|c}
\hline Metal & $\begin{array}{c}\text { Sorbing } \\
\text { Material }\end{array}$ & $\mathrm{A}^{(\mathrm{b})}$ & $\mathrm{B}$ & $\mathrm{D}$ & $\mathrm{E}$ & $\begin{array}{c}\mathrm{C}_{\mathrm{t}}(1273 \mathrm{~K}) \\
(\mathrm{mmo1} / \mathrm{kg})\end{array}$ \\
\hline Cesium & Matrix & 19.33 & -47290 & 1.52 & 4338 & $13.7^{(\mathrm{c})}$ \\
Cesium & $\mathrm{P}_{3}$ JHAN & 23.61 & -39027 & 0.55 & 5690 & $1.8^{(\mathrm{d})}$ \\
\hline
\end{tabular}

(a) Used as input to the following expressions:

$$
\begin{aligned}
& \ln P_{F}=A+\frac{B}{T}+(D+E / T) \ln C \\
& \ln P_{H}=A+\frac{B}{T}+(D+E / T) \ln C_{t}+\ln C,
\end{aligned}
$$

where $P_{F}=$ pressure in the Freundlich regime $(\mathrm{Pa})$,

$$
\begin{aligned}
\mathrm{P}_{\mathrm{H}}= & \text { pressure in the Henrian regime }(\mathrm{Pa}), \\
\mathrm{T}= & \text { temperature }(\mathrm{K}), \\
\mathrm{C}= & \text { isotope concentration }(\mathrm{mmol} / \mathrm{kg}), \\
\mathrm{C}_{\mathrm{t}}= & \begin{array}{l}
\text { transition concentration from Henrian to Freundlich behavior } \\
(\text { mmol } / \mathrm{kg}) .
\end{array}
\end{aligned}
$$

(b) To calculate $\mathrm{P}_{\mathrm{F}}$ or $\mathrm{P}_{\mathrm{H}}$ in atmospheres rather than Pascals, subtract $11.53\left(=\ln 1.03 \times 10^{5}\right)$ from $A$ and solve.

${ }^{(c)}$ Value of $C_{t}$ derived from: $C_{t}=24.29-8.289 \times 10^{-3} \mathrm{~T}$

${ }^{(d)}$ Value of $C_{t}$ derived from: $C_{t}=2.747-7.389 \times 10^{-4} \mathrm{~T}$ ( $P_{3}$ JHAN graphite) 


\subsection{OPERATIONAL MEASUREMENTS}

In-pile measurements important to fission metal release analyses included fuel element and coolant temperatures, fission gas release, coolant pressure, and coolant flow rates.

\subsubsection{Mean Operating Conditions}

The temperatures associated with the fuel element, helium coolant, and graphite plateout sleeves were measured continuously during irradiation. Table 4-2 presents a summary of the mean operating conditions for the loop, including temperatures, axial power factors, fuel element power, and coolant pressure and flow. The time-dependent fuel element power was derived from the operating gas inlet and gas outlet temperatures and the fuel burnup noted during postirradiation examination (PIE). Fuel element temperatures were calculated using input from the three Chromel-Alumel thermocouples positioned within the fuel element.

\subsubsection{Pission Gas Release}

Measurement of the release of gaseous fission products was carried out intermittently throughout the irradiation. In-pile data are presented in Table 4-3. These data were coupled with the observed end-of-life (EOL) fraction of broken fissile particles and used to calculate the time-dependent particle failure fractions present during in-pile operation. Particle failure fractions are important parameters in reference HTGR design calculations of cesium release since failed particles are a major source of cesium. Since SSL-1 contained no bare fuel kernels to provide a known source concentration for release predictions, measurement of fission gas release was the principal means used to determine the failure fractions of the all-TRISO fuel. The in-pile release of $\mathrm{Kr}-85 \mathrm{~m}$ is shown in $\mathrm{Fig}$. 4-1, along with the peak operating fuel temperature during the six cycles of operation. 
TABLE 4-2

MEAN OPERATING CONDITIONS FOR THE SSL-1 LOOP TEST

\begin{tabular}{|c|c|c|c|c|c|c|c|c|c|}
\hline Variable & $\begin{array}{c}1^{(a)} \\
\text { (bottom) }\end{array}$ & 2 & 3 & 4 & 5 & 6 & 7 & 8 & $\begin{array}{c}9 \\
\text { (top) }\end{array}$ \\
\hline Axial power factor (APF) & 0.74 & 0.84 & 0.92 & 0.98 & 1.0 & 0.97 & 0.92 & 0.83 & 0.73 \\
\hline Power $\left(\mathrm{mW} / \mathrm{mm}^{3}\right)(\mathrm{b})$ & 45.9 & 52.1 & 57.1 & 60.8 & 62.1 & 60.2 & 57.1 & 51.1 & 45.3 \\
\hline \multicolumn{10}{|l|}{$\begin{array}{l}\text { Time-average } \\
\text { temperature }(\mathrm{K})\end{array}$} \\
\hline Fuel rod centerline & 1403 & 1442 & 1465 & 1482 & 1477 & 1449 & 1400 & 1328 & 1235 \\
\hline Fuel rod surface & 1295 & 1315 & 1330 & 1337 & 1329 & 1304 & 1264 & 1206 & 1131 \\
\hline $\begin{array}{l}\text { Graphite fuel hole } \\
\text { surface }\end{array}$ & 1212 & 1224 & 1234 & 1235 & 1226 & 1202 & 1165 & 1114 & 1064 \\
\hline $\begin{array}{l}\text { Graphite coolant hole } \\
\text { surface }\end{array}$ & 1168 & 1172 & 1177 & 1175 & 1164 & 1141 & 1106 & 1061 & 1003 \\
\hline Helium coolant & 918 & 903 & 887 & 871 & 854 & 834 & 822 & 808 & 745 \\
\hline \multicolumn{10}{|l|}{$\begin{array}{l}\text { He coolant flow in } 12-\mathrm{mm} \\
\text { hole }(\mathrm{mol} / \mathrm{s})\end{array}$} \\
\hline $\begin{array}{l}\text { He coolant pressure } \\
{[\mathrm{MPa}(\mathrm{atm})]}\end{array}$ & - & & & & $\begin{array}{l}6.08 \\
(60)\end{array}$ & & & & \\
\hline
\end{tabular}

(a) Rod layer

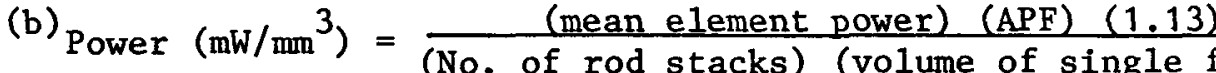

$=\frac{(14.5 \mathrm{~kW})(\mathrm{APF})(1.13)\left(10^{6} \mathrm{~mW} / \mathrm{kW}\right)}{(3)(9)(50 \mathrm{~mm})\left(195.6 \mathrm{~mm}^{2}\right)}=62.05(\mathrm{APF}) \mathrm{mW} / \mathrm{mm}^{3}$ 
TABLE 4-3

IN-PILE FRACTIONAL RELEASES OF KRYPTON AND XENON ISO'TOPFS FROM THE SSL-1 LOOP

\begin{tabular}{|c|c|c|c|c|c|c|c|c|c|c|c|}
\hline $\begin{array}{c}\text { Time } \\
\text { (EFPD) }\end{array}$ & $\mathrm{Kr}-90$ & $\mathrm{Kr}-89$ & $\mathrm{Kr}-87$ & $\mathrm{Kr}-88$ & $\mathrm{Kr}-85 \mathrm{~m}$ & $\mathrm{Xe}-139$ & $\mathrm{Xe}-137$ & $\mathrm{Xe}-138$ & $\mathrm{Xe}-135 \mathrm{~m}$ & $\mathrm{Xe}-135$ & $\mathrm{Xe}-133$ \\
\hline 0.081 & $8.96 \times 10^{-8}$ & $2.43 \times 10^{-7}$ & - & - & - & $4.00 \times 10^{-8}$ & $1.00 \times 10^{-7}$ & $1.45 \times 10^{-7}$ & - & - & - \\
\hline 1.64 & $1.29 \times 10^{-7}$ & $3.78 \times 10^{-7}$ & $1.54 \times 10^{-6}$ & $1.45 \times 10^{-6}$ & $1.81 \times 10^{-6}$ & $4.16 \times 10^{-8}$ & $7.93 \times 10^{-8}$ & $1.43 \times 10^{-7}$ & - & - & - \\
\hline 8.7 & $9.82 \times 10^{-8}$ & $2.83 \times 10^{-7}$ & - & - & - & $3.37 \times 10^{-8}$ & $4.86 \times 10^{-8}$ & $1.09 \times 10^{-7}$ & - & - & - \\
\hline 15.7 & $1.63 \times 10^{-7}$ & $5.50 \times 10^{-7}$ & $3.24 \times 10^{-6}$ & $3.89 \times 10^{-6}$ & $7.16 \times 10^{-6}$ & $4.56 \times 10^{-8}$ & $1.62 \times 10^{-7}$ & $2.16 \times 10^{-7}$ & $7.50 \times 10^{-7}$ & $8.66 \times 10^{-7}$ & $1.84 \times 10^{-5}$ \\
\hline 21.3 & $1.27 \times 10^{-7}$ & $5.59 \times 10^{-7}$ & $3.13 \times 10^{-6}$ & $3.40 \times 10^{-6}$ & $5.72 \times 10^{-6}$ & $4.68 \times 10^{-8}$ & $1.41 \times 10^{-7}$ & $2.78 \times 10^{-7}$ & $6.19 \times 10^{-7}$ & $7.06 \times 10^{-7}$ & \\
\hline 25.3 & $2.58 \times 10^{-7}$ & $1.20 \times 10^{-6}$ & $6.01 \times 10^{-6}$ & $7.06 \times 10^{-6}$ & $1.08 \times 10^{-5}$ & $1.06 \times 10^{-7}$ & $3.66 \times 10^{-7}$ & $4.25 \times 10^{-7}$ & $1.31 \times 10^{-6}$ & $2.22 \times 10^{-6}$ & $1.49 \times 10^{-5}$ \\
\hline 36.0 & $3.14 \times 10^{-6}$ & $1.05 \times 10^{-5}$ & $5.78 \times 10^{-5}$ & $6.24 \times 10^{-5}$ & $8.45 \times 10^{-5}$ & $1.22 \times 10^{-6}$ & $2.80 \times 10^{-6}$ & $6.88 \times 10^{-6}$ & $1.46 \times 10^{-5}$ & $2.53 \times 10^{-5}$ & $9.22 \times 10^{-4}$ \\
\hline 38.5 & $5.12 \times 10^{-6}$ & $2.30 \times 10^{-5}$ & $1.13 \times 10^{-4}$ & $1.21 \times 10^{-4}$ & $1.65 \times 10^{-4}$ & - & $5.00 \times 10^{-6}$ & $1.27 \times 10^{-5}$ & $2.34 \times 10^{-5}$ & $4.42 \times 10^{-5}$ & - \\
\hline 45.0 & $1.14 \times 10^{-5}$ & $4.90 \times 10^{-5}$ & $2.39 \times 10^{-4}$ & $2.98 \times 10^{-4}$ & $3.78 \times 10^{-4}$ & $3.02 \times 10^{-6}$ & $1.25 \times 10^{-5}$ & $1.94 \times 10^{-5}$ & $9.68 \times 10^{-5}$ & $1.07 \times 10^{-4}$ & $2.31 \times 10^{-3}$ \\
\hline 53.5 & $2.05 \times 10^{-5}$ & $9.20 \times 10^{-5}$ & $5.99 \times 10^{-4}$ & $6.16 \times 10^{-4}$ & $8.42 \times 10^{-4}$ & - & $2.23 \times 10^{-5}$ & $5.23 \times 10^{-5}$ & $1.62 \times 10^{-4}$ & $2.24 \times 10^{-4}$ & $4.60 \times 10^{-3}$ \\
\hline 58.5 & $2.09 \times 10^{-5}$ & $1.03 \times 10^{-4}$ & $6.13 \times 10^{-4}$ & $7.58 \times 10^{-4}$ & $9.84 \times 10^{-4}$ & $6.65 \times 10^{-6}$ & $2.28 \times 10^{-5}$ & $4.43 \times 10^{-5}$ & $1.46 \times 10^{-4}$ & $2.29 \times 10^{-4}$ & $2.11 \times 10^{-3}$ \\
\hline 65.0 & $2.25 \times 10^{-5}$ & $1.11 \times 10^{-4}$ & $6.97 \times 10^{-4}$ & $8.23 \times 10^{-4}$ & $1.10 \times 10^{-3}$ & $5.84 \times 10^{-6}$ & $2.27 \times 10^{-5}$ & $5.62 \times 10^{-5}$ & $1.72 \times 10^{-4}$ & $2.41 \times 10^{-4}$ & $2.46 \times 10^{-3}$ \\
\hline 72.0 & $2.15 \times 10^{-5}$ & $1.06 \times 10^{-4}$ & $6.56 \times 10^{-4}$ & $7.43 \times 10^{-4}$ & $1.00 \times 10^{-3}$ & $5.96 \times 10^{-6}$ & $2.52 \times 10^{-5}$ & $3.88 \times 10^{-5}$ & $1.54 \times 10^{-4}$ & $2.79 \times 10^{-4}$ & $3.94 \times 10^{-3}$ \\
\hline 80.0 & $1.85 \times 10^{-5}$ & $9.15 \times 10^{-5}$ & $5.59 \times 10^{-4}$ & $6.62 \times 10^{-4}$ & $8.99 \times 10^{-4}$ & $5.40 \times 10^{-6}$ & $1.61 \times 10^{-5}$ & $4.06 \times 10^{-5}$ & $9.81 \times 10^{-5}$ & $2.08 \times 10^{-4}$ & $1.05 \times 10^{-3}$ \\
\hline 88.0 & $1.91 \times 10^{-5}$ & $8.28 \times 10^{-5}$ & $4.82 \times 10^{-4}$ & $5.19 \times 10^{-4}$ & $6.43 \times 10^{-4}$ & $5.69 \times 10^{-6}$ & $2.28 \times 10^{-5}$ & $3.91 \times 10^{-5}$ & $1.52 \times 10^{-4}$ & $1.64 \times 10^{-4}$ & $2.17 \times 10^{-3}$ \\
\hline 94.0 & $1.71 \times 10^{-5}$ & $7.54 \times 10^{-5}$ & $4.53 \times 10^{-4}$ & $5.35 \times 10^{-4}$ & $7.28 \times 10^{-4}$ & $6.15 \times 10^{-6}$ & $1.62 \times 10^{-5}$ & $3.22 \times 10^{-5}$ & $1.65 \times 10^{-4}$ & $1.97 \times 10^{-4}$ & $3.43 \times 10^{3}$ \\
\hline 102.4 & $1.41 \times 10^{-5}$ & $6.48 \times 10^{-5}$ & $3.89 \times 10^{-4}$ & $4.63 \times 10^{-4}$ & $6.55 \times 10^{-4}$ & $5.34 \times 10^{-6}$ & $1.42 \times 10^{-5}$ & $1.89 \times 10^{-5}$ & $1.09 \times 10^{-4}$ & $1.66 \times 10^{-4}$ & $2.28 \times 10^{3}$ \\
\hline 106.4 & $1.33 \times 10^{-5}$ & $6.10 \times 10^{-5}$ & $3.70 \times 10^{-4}$ & $4.25 \times 10^{-4}$ & $5.77 \times 10^{-4}$ & $3.42 \times 10^{-6}$ & $1.28 \times 10^{-5}$ & $1.81 \times 10^{-5}$ & $1.24 \times 10^{-4}$ & $1.52 \times 10^{-4}$ & $2.63 \times 10^{3}$ \\
\hline 113.0 & $1.65 \times 10^{-5}$ & $6.63 \times 10^{-5}$ & $3.93 \times 10^{-4}$ & $4.33 \times 10^{-4}$ & $6.03 \times 10^{-4}$ & $4.11 \times 10^{-6}$ & $1.53 \times 10^{-5}$ & $2.08 \times 10^{-5}$ & $1.44 \times 10^{-4}$ & $1.51 \times 10^{-4}$ & $2.22 \times 10^{3}$ \\
\hline 120.0 & $171 \times 10^{-5}$ & $6.39 \times 10^{-5}$ & $3.46 \times 10^{-4}$ & $4.26 \times 10^{-4}$ & $5.73 \times 10^{-4}$ & $6.10 \times 10^{-6}$ & $1.57 \times 10^{-5}$ & $3.29 \times 10^{-5}$ & $1.63 \times 10^{-4}$ & $1.71 \times 10^{-4}$ & $3.17 \times 10^{3}$ \\
\hline
\end{tabular}




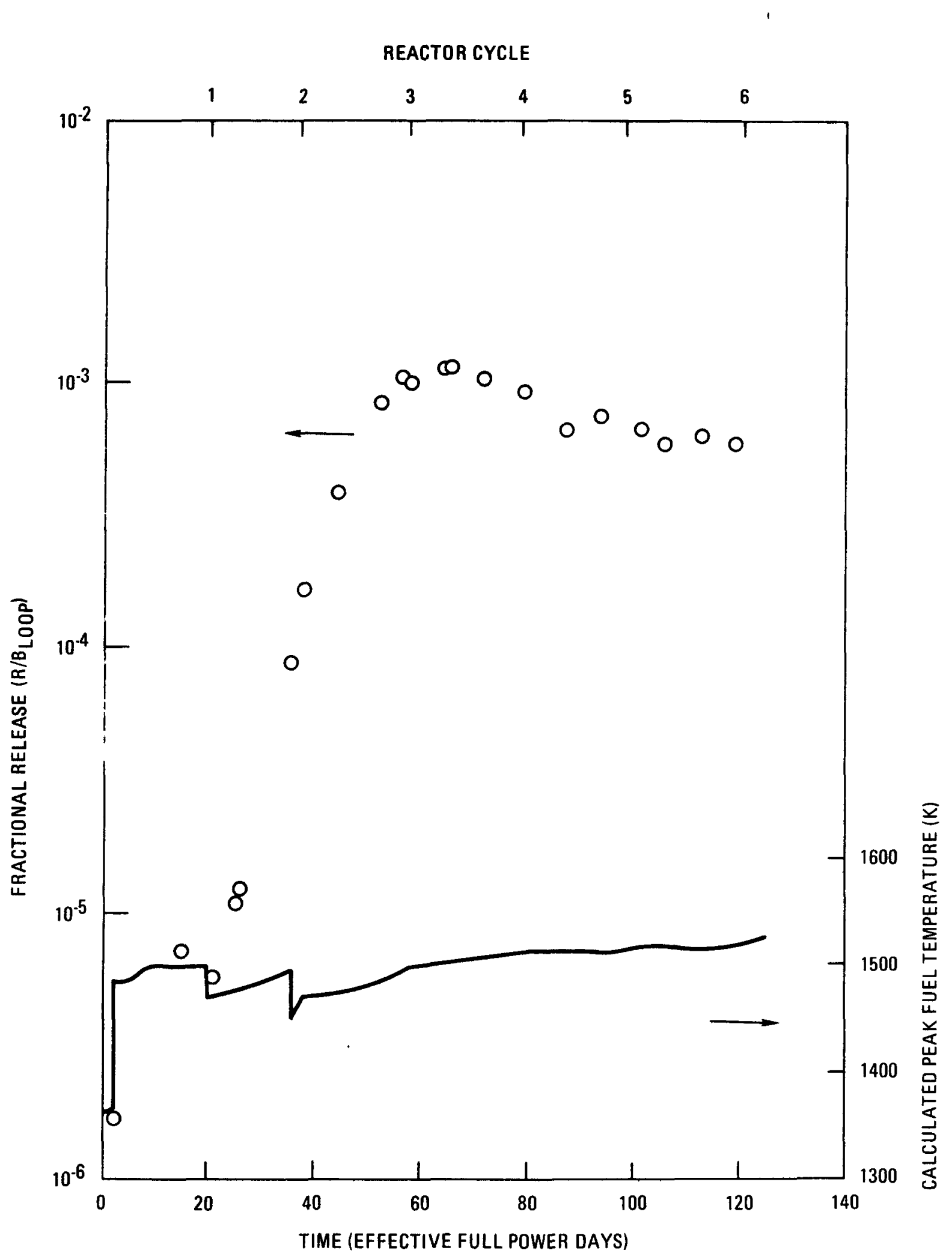

Fig. 4-1. Fission gas release $(\mathrm{Kr}-85 \mathrm{~m})$ and calculated peak fuel temperatures during operation of SSL-1 loop test 


\subsection{POSTIRRADIATION EXAMINATION (PIE) MEASUREMENTS}

The CEA carried out the PIE of the fuel element and selected circuit components. Measurements of direct importance to cesium release studies are discussed below.

\subsubsection{Fuel Element PIE Measurements}

PIE measurements were carried out on the fuel particles, matrix material, fuel rods, and graphite fuel body.

4.3.1.1. Fuel Particle Fallure. Modeling of metallic release from the SSL-1 fuel element required an estimate of time-dependent failed fissile and fertile particle fractions.

Determination of Fraction of Falled Fertile Particles, $F_{t h}$. The EOL fraction of broken fertile particles was assumed to be zero. This result was based in part upon the observed fission gas release and PIE measurements from this and other experiments. Examination of Fig. 4-1 reveals the following:

1. The initial (R/B) loop was quite low and well within the design expectations, indicating that contamination in the fuel was low at beginning of life (BOL).

2. The $(R / B)_{100 p}$ started to rise very quickly into the irradiation, such that shortly after the start of the fourth cycle ( 65 EFPD) the $(\mathrm{R} / \mathrm{B})_{\text {loop }}$ had increased to $1.2 \times 10^{-3}$.

3. The $(R / B)_{\text {loop }}$ showed a slowly decreasing value in time throughout the remainder of the irradiation.

Since extensive fission gas release was evident as early as the second cycle (>20 EFPD) and the fraction of fissions in the fertile particles was low $(<25 \%)$ at 65 EFPD when the $(R / B)$ loop had stabilized, it was assumed for the analysis that all particle failure took place in the fissile particles. 
Additional analysis of the fission gas release data provided confirmation of the above assumption. Figure 4-2 shows the release-to-birth rate based on birth in the fissile particles only, $(R / B)$ loop (fissile) If no further fissile particle failure occurred after 65 days, (R/B) 1 loop (fissile) would remain constant.* Any contribution to release from failed fertile particles would have resulted in an increasing value of ( $R / B$ ) ${ }_{100 p}$ (fissile) since births in the fertile particles would not have been included in the calculation of $B$. (Note that the fraction of fissions in the fertile particles at EOL was approaching $50 \%$ ) Since a decrease in ( $R / B$ ) loop (fissile) was observed, the presence of significant fertile failure at EOL could not have existed. This conclusion is substantiated in part by other in-pile results. Similar fertile fuel was irradiated as loose particles in the GA-DOE P13S capsule (design temperature of $1323 \mathrm{~K}, 4.1 \%$ FIMA burnup) (Ref. 25). In these tests, where the fertile fuel experienced higher particle burnup than in SSL-1 (0.9\% FIMA), fertile failure fractions of less than $1 \%$ were noted from metallographic examination.

As a result of these findings, zero fertile failure was assumed. A1though it is possible that some small failure of fertile particle coatings may have occurred near EOL, no reliable means of determining such a small value existed. Deletion of this small fraction of potentially failed fertile particles has a negligible impact on calculated cesium release from the fuel element.

Determination of the Fraction of Failed Fissile Particles, $F_{u}$. The EOL fissile particles failure fraction at each rod layer was determined principally from $R / B$ measurements carried out on individual fuel rods removed

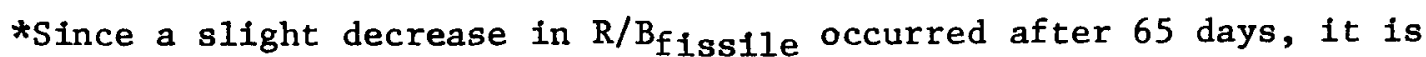
possible that radiation-induced structural changes may have taken place in the

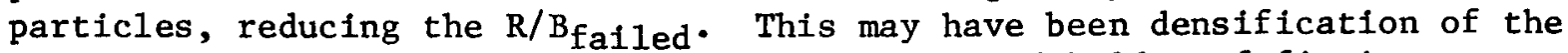
kernel or the buffer layer, resulting in increased holdup of fission gases. Close scrutiny of the measured values of $R / B$ loop (fissile) indicates a stabilization near EOL. It could be hypothesized that a falled fertile contribution to release was compensating structural change effects. Even if this were occurring, the cesium release contribution from the apparent fertile fraction would have been small and would have fallen well within the bounds of the failed fissile particle uncertainty. 


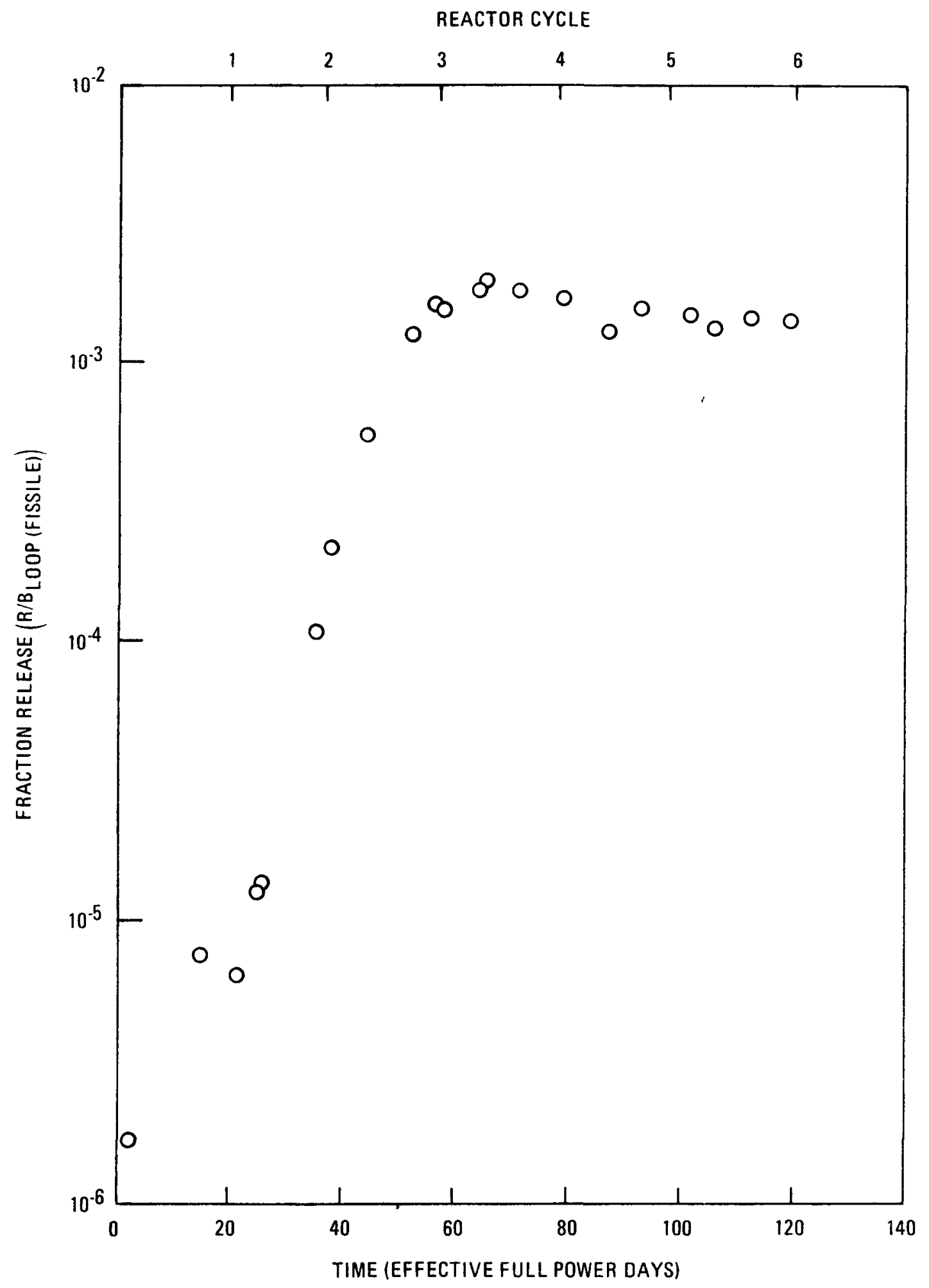

Fig. 4-2. Fission gas release $(\mathrm{Kr}-85 \mathrm{~m})$ during the SSL-1 1oop test based on births in the fissile particles only 
from the fuel body after irradiation. Nine fuel rods from column $A$, manufactured by the packed-bed method, and nine rods from column $C$, manufactured by the cure-in-place method, were submitted for postirradiation measurements of $\mathrm{R} / \mathrm{B}$ at $873 \mathrm{~K}$. This temperature was selected because it was near the maximum attainable with the in-pile furnace used by the CEA. The results shown in Table 4-4 were used to assign the fissile particle failure fractions at each rod layer. This was done by calculating the average fractional release of $\mathrm{Kr}-85 \mathrm{~m}$ per rod 1ayer* and using this as input to the following expression:

$$
(R / B) \text { 1ayer } 2^{(T)}=\bar{F}_{\text {layer } 2}{ }^{(R / B)} \text { failed }(T) \text {, }
$$

where $(R / B)$ layer $2^{(T)}=$ fractional release of $\mathrm{Kr}-85 \mathrm{~m}$ from fuel rods in layer 2 at temperature $\mathrm{T}(=873 \mathrm{~K})$,

$$
\begin{aligned}
\overline{\mathrm{F}}_{\text {layer } 2}= & \text { fraction of fissions in failed particles at rod } \\
& \text { layer } 2 \\
(\mathrm{R} / \mathrm{B})_{\text {failed }}(\mathrm{T})= & \text { fractional release from failed particle at tempera- } \\
& \text { ture } \mathrm{T}(=873 \mathrm{~K}) .
\end{aligned}
$$

The use of Eq. 4-2 assumes that release from heavy metal contamination in the particle coatings and matrix material is negligible. The varying fraction of fissions in fissile and fertile particles is accounted for in Eq. 4-3:

$$
\begin{gathered}
\left(\mathrm{R} / \mathrm{B}_{\text {layer } 2}={ }_{\text {failed }}=\right. \\
\frac{\mathrm{Y}_{235} \mathrm{Rf}_{\mathrm{u}(\text { layer } 2)}+\mathrm{Y}_{233}(1-\Psi)(\alpha) \mathrm{f}_{\mathrm{u}(\text { layer } 2)}+\mathrm{Y}_{233}(1-\Psi)(1-\alpha) \mathrm{f}_{\text {th (layer 2) }}}{\mathrm{Y}_{235} \Psi+\mathrm{Y}_{233}(1-\Psi)}
\end{gathered}
$$

*Since two of the three rod layers were cured-in-place, the data for rods from column $\mathrm{C}$ were doubly weighted:

$$
(\mathrm{R} / \mathrm{B})_{\text {1ayer } 2}=\frac{(\mathrm{R} / \mathrm{B})_{\mathrm{A}}+2(\mathrm{R} / \mathrm{B})_{\mathrm{C}}}{3}
$$


TABLE $4-4$

EOL R/B (Kr-85m AT $873 \mathrm{~K})$ FOR EIGHTEEN FUEL RODS FROM THE SSL-1 LOOP TEST

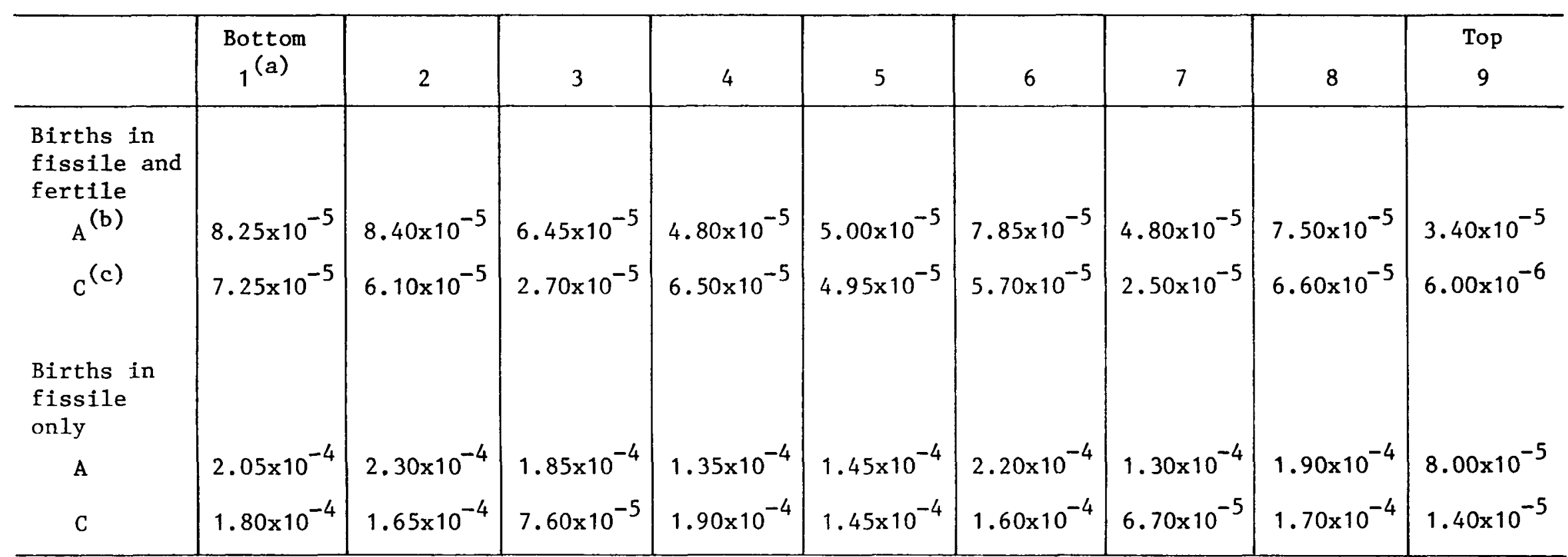

(a) Fuel rod number.

(b) $A=$ fuel rods cured by the packed-bed method.

${ }^{(c)} \mathrm{C}=$ fuel rods cured-in-place. 
where

$$
\begin{aligned}
& \mathrm{Y}_{235}, \mathrm{Y}_{233}=\text { fission yield of } \mathrm{Kr}-85 \mathrm{~m} \text { from fission of } \\
& \mathrm{U}-235(=0.0133) \text { and } \mathrm{U}-233(=0.0221) \text {, } \\
& \text { respectively, } \\
& \Psi=\text { fraction of fissions in } U-235 \text { (see Table 4-5), }
\end{aligned}
$$

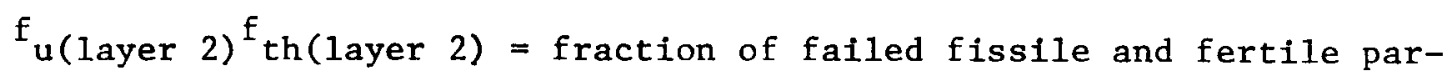

$$
\begin{aligned}
& \text { ticles, respectively, at rod layer } 2 \text {, } \\
& \alpha=\text { fraction of fertile material in fissile par- } \\
& \text { ticles }(=0.24) \text {. }
\end{aligned}
$$

For the analysis of fissile particle failure, it was assumed that $f_{t h}=0$, as discussed in the previous section. In addition, the fractional release of $\mathrm{Kr}-85 \mathrm{~m}$ using birth in the fissile particle only, (R/B) 1ayer 2(fissile) $(\mathrm{T})$, was used in place of $(R / B)$ layer $2^{(T)}$. With these inputs, Eq. $4-3$ reduces to:

$$
(\mathrm{R} / \mathrm{B})_{\text {layer }} 2(\text { fissile })=(\mathrm{R} / \mathrm{B})_{\text {failed }} \cdot \mathrm{f}_{\mathrm{u}(\text { layer } 2)} \text {. }
$$

In order to calculate EOL failure fractions, it is necessary to assign a value to $(R / B)_{\text {failed. }} \mathrm{CEA}$ assigned $(\mathrm{R} / \mathrm{B})_{\text {failed }}=5 \times 10^{-3}(\mathrm{Kr}-85 \mathrm{~m}$ at $873 \mathrm{~K})$. This value was obtained from "laser-failed"* particles of the same type as those irradiated in SSL-1 and leads to a calculated EOL failure fraction $\overline{\mathrm{F}}_{\mathrm{u}}$ $\approx 3 \%$. Values of $(R / B)$ failed of $2 \times 10^{-2}(1323 \mathrm{~K})$ and $3.4 \times 10^{-2}(1523 \mathrm{~K})$ were also noted by the CEA during higher temperature runs (Ref. 26). These results are important for they were obtained from particles irradiated in the SSL-1 loop and should therefore provide the most representative value of $(R / B)_{\text {failed }}$ for use in solving Eq. 4-4. However, an additional finding should be noted. The CEA noted a burnup dependence of release, $(R / B)$ failed varying from $5 \times 10^{-4}(\mathrm{Kr}-85 \mathrm{~m}$ at $873 \mathrm{~K})$ at $0 \%$ burnup to $5 \times 10^{-3}$ at $7 \%$ burnup; similar variations are found at the higher temperatures. Axial dependent failure fractions were derived from these reirradiation measurements using $(\mathrm{R} / \mathrm{B})_{\mathrm{failed}}=$ $5 \times 10^{-3}(873 \mathrm{~K})$ in Eq. 4-4. A summary of the calculated particle failure is shown in Table 4-6.

* Laser-failing is a method used to fail intact particles. A single intact particle, either unirradiated or irradiated, is subjected to a laser beam pulse. The high energy pulse introduces a "pinhole" in the particle coatings which allows fission gases to escape. This particle is then irradiated and the $(R / B)$ failed measured. 
TABLE 4-5

TIME-DEPENDENT FRACTION OF FISSIONS IN U-235 AND U-233 IN SSL-1 FISSILE AND FERTILE PARTICLES

\begin{tabular}{|c|c|c|c|c|c|}
\hline $\begin{array}{l}\text { Irradiation } \\
\text { Cycle } \\
\text { Number }\end{array}$ & $\begin{array}{l}\text { Time Step } \\
\text { (EFPD) }\end{array}$ & $\begin{array}{c}\text { Fraction of Fissions } \\
\text { in U-235, } \psi\end{array}$ & $\begin{array}{c}\text { Fraction of Fissions } \\
\text { in } U-233,(1-\psi)\end{array}$ & $\begin{array}{l}\text { Fraction of } \\
\text { Fissions, Fissile } \\
{[\Psi+(1-\Psi)(0.24)]}\end{array}$ & $\begin{array}{c}\text { Fraction of } \\
\text { Fissions, Fertile } \\
{[(1-\Psi)(0.76)]}\end{array}$ \\
\hline 1 & $\begin{array}{r}2.5 \\
8.5 \\
20.5\end{array}$ & $\begin{array}{l}0.989 \\
0.976 \\
0.946\end{array}$ & $\begin{array}{l}0.011 \\
0.024 \\
0.054\end{array}$ & $\begin{array}{l}0.992 \\
0.982 \\
0.959\end{array}$ & $\begin{array}{l}0.008 \\
0.018 \\
0.041\end{array}$ \\
\hline 2 & $\begin{array}{l}22.5 \\
30.0 \\
37.5 \\
40.0\end{array}$ & $\begin{array}{l}0.909 \\
0.878 \\
0.832 \\
0.799\end{array}$ & $\begin{array}{l}0.091 \\
0.122 \\
0.168 \\
0.201\end{array}$ & $\begin{array}{l}0.931 \\
0.907 \\
0.872 \\
0.847\end{array}$ & $\begin{array}{l}0.069 \\
0.093 \\
0.128 \\
0.153\end{array}$ \\
\hline 3 & $\begin{array}{l}48.5 \\
57.5 \\
60.0\end{array}$ & $\begin{array}{l}0.762 \\
0.696 \\
0.654\end{array}$ & $\begin{array}{l}0.238 \\
0.304 \\
0.346\end{array}$ & $\begin{array}{l}0.819 \\
0.769 \\
0.737\end{array}$ & $\begin{array}{l}0.181 \\
0.231 \\
0.263\end{array}$ \\
\hline 4 & $\begin{array}{l}69.0 \\
78.0 \\
79.5\end{array}$ & $\begin{array}{l}0.605 \\
0.564 \\
0.526\end{array}$ & $\begin{array}{l}0.395 \\
0.436 \\
0.474\end{array}$ & $\begin{array}{l}0.700 \\
0.669 \\
0.640\end{array}$ & $\begin{array}{l}0.300 \\
0.331 \\
0.360\end{array}$ \\
\hline 6 & $\begin{array}{l}110.0 \\
120.5\end{array}$ & $\begin{array}{l}0.395 \\
0.354\end{array}$ & $\begin{array}{l}0.605 \\
0.646\end{array}$ & $\begin{array}{l}0.540 \\
0.509\end{array}$ & $\begin{array}{l}0.460 \\
0.491\end{array}$ \\
\hline
\end{tabular}


TABLE 4-6

SSL- 1 OPERATIONAL FUEL PARTICLE FAILIRE. DATA USFI) AS INYI! TO FIPERQ

\begin{tabular}{|c|c|c|c|c|c|c|c|c|c|c|c|}
\hline \multirow{2}{*}{$\begin{array}{c}\text { Irradiation } \\
\text { Cycle } \\
\text { Number }\end{array}$} & \multirow{2}{*}{$\begin{array}{c}\text { Time Step } \\
\text { (EFPD) }\end{array}$} & \multirow{2}{*}{$\begin{array}{l}\text { Fraction of } \\
\text { Failed Fertile } \\
\text { Particles, Fth }\end{array}$} & \multicolumn{9}{|c|}{ Fraction of Failed Fissile Particles, Fu ${ }^{(a)}$} \\
\hline & & & $1^{(b)}$ & 2 & 3 & 4 & 5 & 6 & 7 & 8 & 9 \\
\hline \multirow[t]{3}{*}{1} & 2.5 & 0 & $3.3 \times 10^{-4}$ & $3.8 \times 10^{-5}$ & $2.2 \times 10^{-5}$ & $3.4 \times 10^{-5}$ & $2.9 \times 10^{-5}$ & $3.6 \times 10^{-5}$ & $1.8 \times 10^{-5}$ & $3.5 \times 10^{-5}$ & $7.0 \times 10^{-6}$ \\
\hline & 8.5 & 0 & $5.5 \times 10^{-4}$ & $5.5 \times 10^{-5}$ & $3.3 \times 10^{-5}$ & $5.0 \times 10^{-5}$ & $4.3 \times 10^{-5}$ & $5.5 \times 10^{-5}$ & $2.6 \times 10^{-5}$ & $5.5 \times 10^{-5}$ & $1.1 \times 10^{-5}$ \\
\hline & 20.5 & 0 & $1.0 \times 10^{-3}$ & $1.0 \times 10^{-4}$ & $6.0 \times 10^{-5}$ & $9.0 \times 10^{-5}$ & $8.0 \times 10^{-5}$ & $8.0 \times 10^{-5}$ & $4.5 \times 10^{-5}$ & $9.5 \times 10^{-5}$ & $1.9 \times 10^{-5}$ \\
\hline \multirow[t]{4}{*}{2} & 22.5 & 0 & $1.8 \times 10^{-3}$ & $1.7 \times 10^{-4}$ & $1.0 \times 10^{-4}$ & $1.6 \times 10^{-4}$ & $1.3 \times 10^{-4}$ & $1.7 \times 10^{-4}$ & $8.0 \times 10^{-5}$ & $1.6 \times 10^{-4}$ & $3.3 \times 10^{-5}$ \\
\hline & 30.0 & 0 & $3.5 \times 10^{-3}$ & $3.5 \times 10^{-4}$ & $2.0 \times 10^{-4}$ & $3.2 \times 10^{-4}$ & $2.7 \times 10^{-4}$ & $3.4 \times 10^{-4}$ & $1.6 \times 10^{-4}$ & $3.3 \times 10^{-4}$ & $6.5 \times 10^{-5}$ \\
\hline & 37.5 & 0 & $1.9 \times 10^{-3}$ & $1.9 \times 10^{-3}$ & $1.1 \times 10^{-3}$ & $1.7 \times 10^{-3}$ & $1.4 \times 10^{-3}$ & $1.8 \times 10^{-4}$ & $8.0 \times 10^{-4}$ & $1.8 \times 10^{-4}$ & $3.6 \times 10^{-5}$ \\
\hline & 40.0 & 0 & $6.0 \times 10^{-3}$ & $6.0 \times 10^{-3}$ & $3.5 \times 10^{-3}$ & $5.5 \times 10^{-3}$ & $4.5 \times 10^{-3}$ & $5.0 \times 10^{-3}$ & $2.8 \times 10^{-3}$ & $5.5 \times 10^{-3}$ & $1.1 \times 10^{-3}$ \\
\hline \multirow[t]{3}{*}{3} & 48.5 & 0 & $1.2 \times 10^{-2}$ & $1.2 \times 10^{-2}$ & $7.0 \times 10^{-3}$ & $1.0 \times 10^{-2}$ & $8.5 \times 10^{-3}$ & $1.1 \times 10^{-2}$ & $5.5 \times 10^{-3}$ & $1.1 \times 10^{-2}$ & $2.2 \times 10^{-3}$ \\
\hline & 57.5 & 0 & $3.5 \times 10^{-2}$ & $3.5 \times 10^{-2}$ & $2.1 \times 10^{-2}$ & $3.2 \times 10^{-2}$ & $2.7 \times 10^{-2}$ & $3.4 \times 10^{-2}$ & $1.6 \times 10^{-2}$ & $3.3 \times 10^{-2}$ & $6.5 \times 10^{-3}$ \\
\hline & 60.0 & 0 & $3.8 \times 10^{-2}$ & $3.7 \times 10^{-2}$ & $2.2 \times 10^{-2}$ & $3.4 \times 10^{-2}$ & $2.9 \times 10^{-2}$ & $3.6 \times 10^{-2}$ & $1.8 \times 10^{-2}$ & $3.5 \times 10^{-2}$ & $7.0 \times 10^{-3}$ \\
\hline \multirow[t]{3}{*}{4} & 69.0 & 0 & 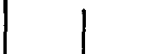 & 1 & 1 & & 1 & 1 & 1 & & 1 \\
\hline & 78.0 & 0 & & & & & & & & & \\
\hline & 79.5 & 0 & & & & & & & & & \\
\hline \multirow[t]{3}{*}{5} & 89.0 & 0 & & & & & & & & & \\
\hline & 98.5 & 0 & & & & & & & & & \\
\hline & 99.5 & 0 & & & & & & & & & \\
\hline \multirow[t]{2}{*}{6} & 110.0 & 0 & & & & & & & & & \\
\hline & 120.5 & 0 & 1 & 1 & 1 & 1 & 1 & 1 & 1 & 1 & I \\
\hline
\end{tabular}

(a) These values represent results based on the value of $(R / B) f_{\text {falled }}=5 \times 10^{-3}(\mathrm{Kr}-85 \mathrm{~m}$ at $873 \mathrm{~K})$ (see Section 4.3.1.1).

(b) Fuel rod layer. 
Additional studies were carried out to define particle failure. An attempt was made to define the failure fraction by observing the appearance of activity "peaks" in the on-line gamma scanning of circulating activity. These peaks were the result of release of long-lived fission gas inventory, principally $\mathrm{Kr}-85$. The $(\mathrm{R} / \mathrm{B})_{\text {loop }}$ during the first $20 \mathrm{EFPD}$ remained quite low, although a small increase in circulating activity was noted. During this time, two discrete particle failures were noted. The failure of over 80 particles was noted during the second irradiation cycle (20 to 40 EFPD). No further peaks could be detected during the final four irradiation cycles due to the high background steady-state activity present. In theory, these data could be used to define $(R / B)$ failed by dividing the observed increase in steady-state $(R / B){ }_{10 o p}$ by the number of discrete peaks noted; however, this method proved to be impractical because of the rapid increase in both failures and release, making it difficult to accurately assign either input. Nonetheless, a value of $(R / B)_{\text {failed }}=5 \%$ to $7 \%$ was estimated based on this method, leading to an average failure fraction at EOL of $\sim 3 \%$.

Metallographic examination of SSL-1 fuel particles from rods $B 1$ and A8 revealed an upper $95 \%$ confidence level failure of $2 \%$ to $4 \%$ based on the relationship between the total particle failures and the number of failed particles observed in a given size particle batch. This value, which includes both fissile and fertile particles, was based on the observation of 2100 particles.

To further characterize the fraction of broken fissile particles, four SSL-1 fuel rods (A5, C1, C4, and $\mathrm{C} 5$, where $\mathrm{A}$ and $\mathrm{C}=$ rod stack designations and 1,4 , and 5 = rod layer designation) were mechanically disaggregated and the particles separated from the matrix material. Approximately 100 particles from fuel rod $\mathrm{C} 4$ were selected for gamma-spectrometry analysis to determine the ratio of $\mathrm{Cs}-137 /(\mathrm{Zr}-95+\mathrm{Nb}-95)$. Of the $48 \mathrm{fissile}$ particles counted, three exhibited ratios more than $2 \sigma$ ( $95.5 \%$ confidence band) below the mean ratio observed (see Table 4-7). These particles were deemed failed. It should be noted that cesium loss ranged from $17 \%$ to $31 \%$. These results, a]though carried out on a limited number of particles, provide an average fissile failed fraction of $6 \%$. A summary of the fuel particle failure fractions determined by the various techniques is presented in Table 4-8. 
TABLE $4-7$
SUMMARY OF CESIUM RETENTION DATA FOR 100 PARTICLES IRRADIATED

\begin{tabular}{|c|c|c|c|c|c|}
\hline Particle Type & $\begin{array}{c}\text { No. of } \\
\text { Particles }\end{array}$ & $\frac{\mathrm{Cs}-137}{\mathrm{Zr}-95+\mathrm{Nb}-95}$ Ratio $^{(\mathrm{b})}$ & $\begin{array}{c}\text { Relative Deviation } \\
\text { From the Mean } \\
(\%)\end{array}$ & Particle Status & $\begin{array}{c}\text { Cesium Release } \\
(\%)\end{array}$ \\
\hline$(8 \mathrm{Th}, \mathrm{U}) \mathrm{O}_{2}$ fissile & 48 & $9170( \pm 1380)$ (mean) & $2 \sigma=15.1 \%^{(c)}$ & $\begin{array}{l}45 \text { intact } \\
3 \text { failed }\end{array}$ & $\sim 1$ \\
\hline$(8 \mathrm{Th}, \mathrm{U}) \mathrm{O}_{2}$ fissile $\mathrm{e}^{(\mathrm{e})}$ & 1 & 7620 & 16.9 & Failed & 17 \\
\hline$(8 \mathrm{Th}, \mathrm{U}) \mathrm{O}_{2}$ fissile $^{(\mathrm{e})}$ & 1 & 7290 & 20.5 & Failed & 21 \\
\hline$(8 \mathrm{Th}, \mathrm{U}) \mathrm{O}_{2}$ fissile $\mathrm{e}^{(\mathrm{e})}$ & 1 & 6330 & 31.0 & Failed & 31 \\
\hline $\mathrm{ThO}_{2}$ fertile & 52 & $12925( \pm 1230)$ & $(2 \sigma=9.5 \%)$ & 52 intact & 0 \\
\hline
\end{tabular}

(a) Mean irradiation temperatures, $1337 \leq \mathrm{T} \leq 1482 \mathrm{~K}$.

(b) Ratio of counts.

(c) The $2 \sigma$ values represent the root mean square deviation about the mean. Values for failed particles represent the deviation of the single particle ratio from the particle batch mean.

(d) A particle was deemed failed if the individual particle count ratio was $2 \sigma(15.1 \%$ for fissile, $9.5 \%$ for fertile) below the respective batch mean.

(e) These three fissile particles were included with the 45 intact fissile particles in the determination of the fissile particle batch mean. 
TABLE 4-8

SUMMARY OF EOL FUEL PARTICLE FAILURE FRACTIONS DETERMINED FROM SSL-1 IN-PILE AND PIE MEASUREMENTS

\begin{tabular}{|c|c|c|c|}
\hline Method of Measurement & $\begin{array}{l}\text { Fissile } \\
\text { Failure } \\
\quad(\%)\end{array}$ & $\begin{array}{l}\text { Fertile } \\
\text { Failure } \\
\quad(\%)\end{array}$ & Comments \\
\hline $\begin{array}{l}\text { In-pile } \mathrm{R} / \mathrm{B} \text { measurement assuming } \\
\mathrm{CEA}(\mathrm{R} / \mathrm{B}) \text { failed }(\mathrm{Kr}-85 \mathrm{~m} \text { at } 1373 \mathrm{~K})= \\
2 \times 10^{-2}\end{array}$ & $7-9$ & 0 & $\begin{array}{l}(\mathrm{R} / \mathrm{B}) \\
\text { fertileop, fissile confirmed zero } \\
\text { particle failure }\end{array}$ \\
\hline $\begin{array}{l}\mathrm{R} / \mathrm{B} \text { measurements on individual fuel } \\
\text { rods (average of a11 rods) assuming } \\
\mathrm{CEA}(\mathrm{R} / \mathrm{B})_{\text {failed }}(873 \mathrm{~K})=5 \times 10^{-3}\end{array}$ & 3 & -- & $\begin{array}{l}\text { CEA }(R / B) \text { failed determined from measure- } \\
\text { ments of release from laser-failed } \\
\text { particles. This is felt to be most } \\
\text { reliable measure of failure fraction. }\end{array}$ \\
\hline $\begin{array}{l}\text { Observation of activity peaks during } \\
\text { continuous on-1ine gamma scan }\end{array}$ & 3 & - & $\begin{array}{l}\text { Calculation carried out by CEA has } \\
\text { large uncertainty }\end{array}$ \\
\hline Metallographic examination* & \multicolumn{2}{|c|}{$\begin{array}{l}2-4 \text { of all } \\
\text { particles }\end{array}$} & $\begin{array}{l}\text { Large uncertainty due to limited } \\
\text { number of particles examined (100) }\end{array}$ \\
\hline $\begin{array}{l}\text { Cesium inventory in particles } \\
\text { irradiated at rod level } 4\end{array}$ & 6 & 0 & $\begin{array}{l}3 \text { failed fissiles in } 48 \text { fissile particles } \\
\text { counted; } 0 \text { failed fertiles in } 52 \text { fertile } \\
\text { particles counted }\end{array}$ \\
\hline *Additional results & & & \\
\hline $\begin{array}{l}\text { Metallographic examination of } \\
\text { particles irradiated in capsule } \\
\text { P13S }\end{array}$ & -- & $<1$ & $\begin{array}{l}\text { Particles from the same batch were } \\
\text { irradiated to significantly higher } \\
\text { FIMA and comparable temperature, yet } \\
\text { exhibited very low failure }\end{array}$ \\
\hline
\end{tabular}


The preponderance of in-pile and PIE data leads to a prediction of $\sim 3 \%$ fissile particles with failed coatings. Having assigned values to the EOL failure fractions for each rod layer, time-dependent fractions were calculated using Eq. 4-5:

$$
f_{u(\text { layer 2) }}(t)=f_{u(\text { layer 2) }} \cdot \frac{(R / B) 1_{\text {oop }}(t)}{(R / B){ }_{10 o p}(E O L)} \text {, }
$$

$$
\text { where } \begin{aligned}
\mathrm{F}_{\mathrm{u}(\text { layer } 2)}(\mathrm{t})= & \text { fissile failure fraction in fuel rods at rod layer } 2 \\
& \text { at time } t, \\
(\mathrm{R} / \mathrm{B}){ }_{\text {loop }}(\mathrm{t})= & \text { fission gas release of the loop at time } t, \\
(\mathrm{R} / \mathrm{B})_{\text {loop }}(\mathrm{EOL})= & \text { fission gas release of the loop at EOL. }
\end{aligned}
$$

This analysis assumed that each rod layer experienced the same fraction of particle failure during each time interval. It is unlikely this is strictly correct since earlier failure may be expected in the higher flux regions; however, no data are available to permit a more accurate modeling of failure. In addition to this assumption, the maximum value of $(R / B) 1$ oop (fissile) (1.8 $x$ $10^{-3}$ ) was used to calculate $\mathrm{F}_{\mathrm{u} \text { (layer 2) }}(\mathrm{t})$ during the last 60 days of irradiation; i.e., the slight decrease in $(\mathrm{R} / \mathrm{B})$ fissile was not taken into account.

4.3.1.2. Fuel Burnup. Three fuel rods were submitted for Nd-148 (a nonmigrating fission metal) analysis to serve as confirmation of the calculated in-pile fuel particle burnup and the calculated fission power distribution in the fuel element. The results revealed that the calculated burnup was $7 \%$ higher than that derived from Nd-148 analyses. Since the latter method is the more accurate of the two, the time-dependent fission power for each rod layer summarized in Table 4-2 incorporated this correction.

4.3.1.3. Fue1 Stack Gamma-Scan Examination. The three fuel columns (A, B, and $C$ ) were gamma scanned after removal from the graphite body to determine the inventory of gamma-emitting isotopes. The nine rods from each fuel rod stack were positioned within a thin-wall aluminum tube and gamma scanned while the tube assembly was rotated to ensure azimuthally averaged results. The gross gamma scan results shown for column $C$ in Fig. 4-3 revea1 


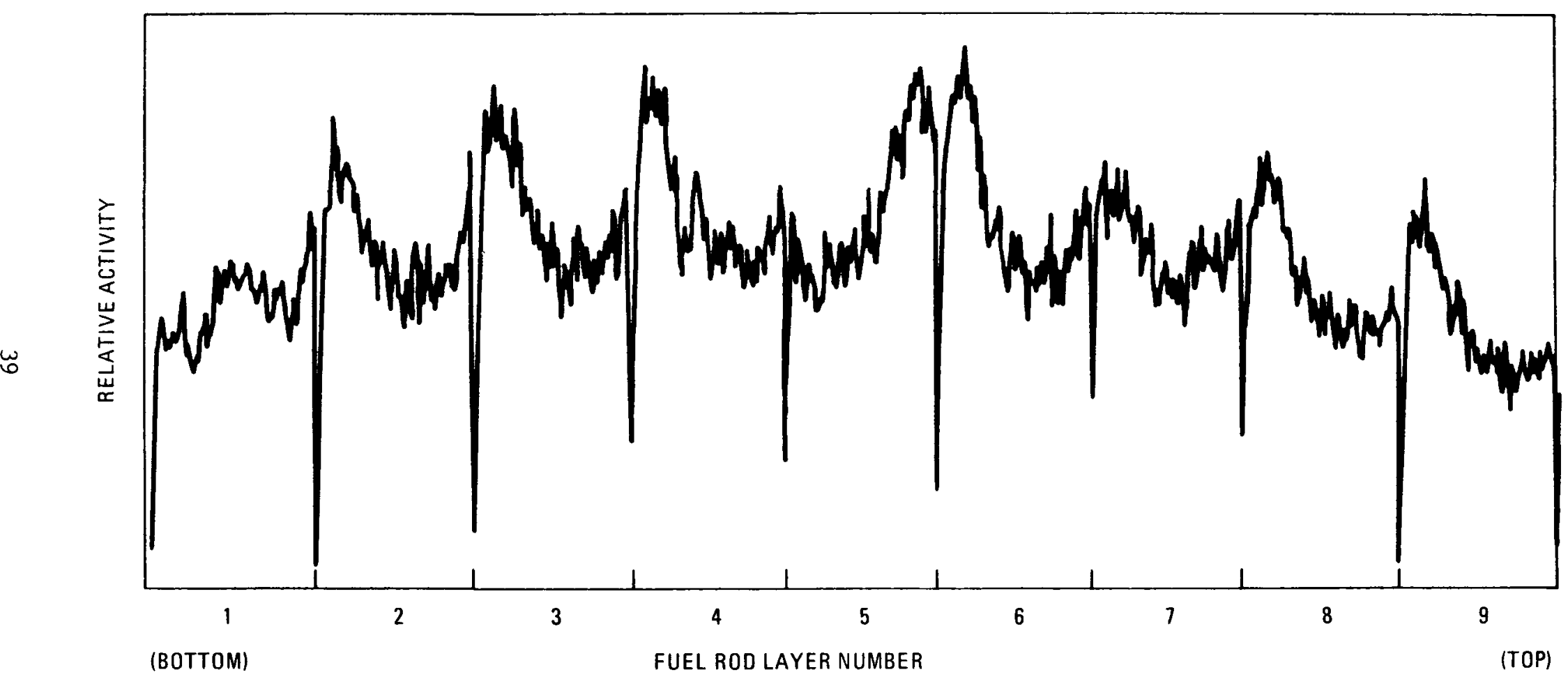

Fig. 4-3. Axial gross gamma scan for fuel rod stack C 
the presence of intrarod fuel loading inhomogeneity; slmilar findings were found for stacks $A$ and $B$. The presence of inhomogeneous particle loading may have resulted from incomplete blending of fissile, fertile, inert, and shim particles during the fuel rod manufacturing process. (The degree of inhomogeneity noted for these rods is not permitted by the HTGR Fuel Specification.)

The presence of inhomogeneity in the fuel rods was not modeled in the release predictions. Calculation of the temperature peaks resulting from the loading inhomogeneity revealed a $\Delta \mathrm{T}_{\max }$ (fuel) $\tilde{\sim}+50 \mathrm{~K}$ in the fuel rod. When calculations of cesium release from fuel particles were carried out, the effect of the temperature increase was found to be small. The maximum temperature increase of the graphite web resulting from inhomogeneity was calculated to be $\Delta \mathrm{T}_{\max }$ (graphite) $\approx+25 \mathrm{~K}$. This increase had virtually no effect on cesium retention and diffusion in graphite at the nominal operating temperatures present in SSL-1. In addition, the uncertainty associated with the operating temperatures was $\pm 40 \mathrm{~K}$, a value larger than $\Delta \mathrm{T}_{\max }$ (graphite), indicating that temperature peaks associated with fuel inhomogeneities fell within the calculated uncertainty.

The activity of selected isotopes in the fuel was also determined from the gamma scans. Of particular interest were the relative concentrations of cesium and zirconium, the latter being a nonmobile fission product at the temperature of this test. Comparison of the Cs/Zr ratio for each rod layer with that of the fuel element average can be used to indicate the presence of cesium release (the limits of sensitivity for the test method are $\pm 10 \%$ ). A review of Fig. 4-4 reveals that in essentially all cases, the discrete fuel rod layer $\mathrm{Cs} / \mathrm{Zr}$ ratio lies within $\pm 2 \sigma$ of the mean $\mathrm{Cs} / \mathrm{Zr}$ ratio. This indicates that in no case did cesium loss from a given rod layer exceed $\sim 12 \%$.

4.3.1.4. Fuel Element Graphite Examination. The axial (Cs-134) and radial (Cs-134 and Cs-137) profiles of cesium in the SSL-1 fuel. element graphite body were measured in the PIE. During removal of the fuel the body was cut into three longitudinal sections; each section included a single fuel rod stack, i.e., A, B, or C (Fig. 4-5). After removal of the fuel rods, 


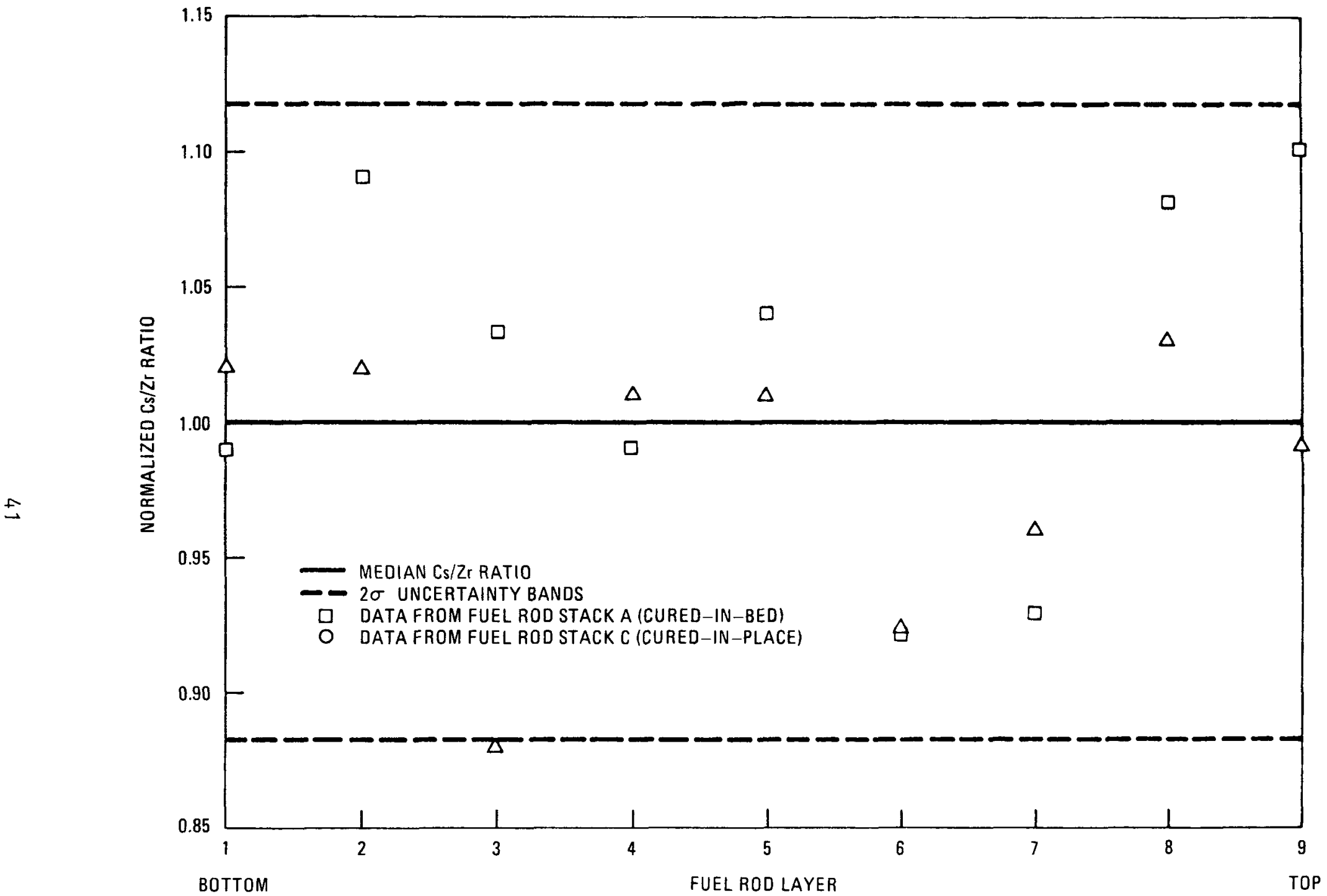

Fig. 4-4. Normalized Cs/Zr ratio versus fuel rod layer for stacked SSL-1 fuel rods ( $\gamma$-scanned after removal from the graphite fuel body) 


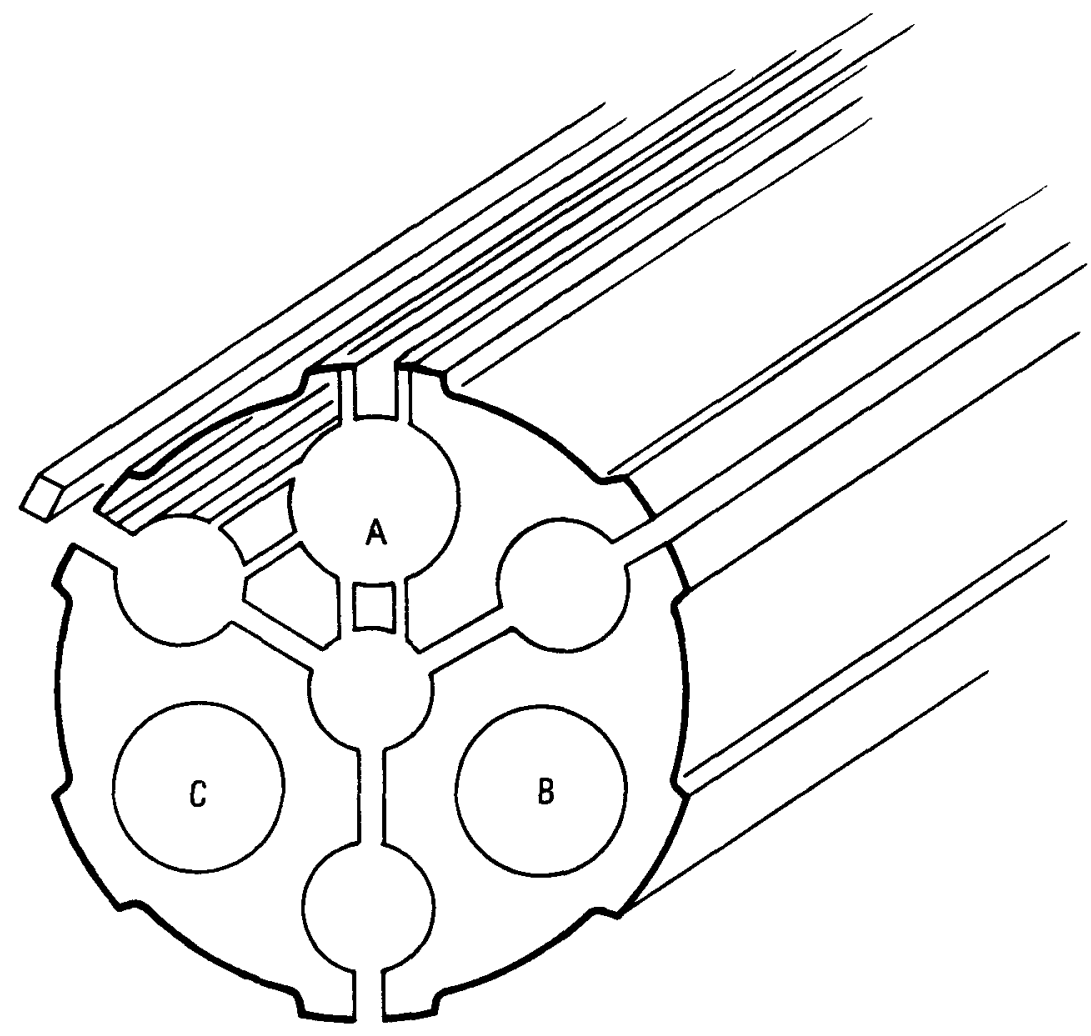

Fig. 4-5. Axial sections from SSL-1 fuel element body ( $A=$ fuel rod stack cured in packed bed and $B, C=$ fuel rod stacks cured in place) 
sections $\mathrm{A}$ and $\mathrm{C}$ were gamma scanned to determine the inventory of Cs-134. Cs-137 was not counted due to high background activity present in the hot cell. The measured Cs-134 inventory and calculated Cs-137 inventory for slices $A$ and $C$ are shown in Fig. 4-6. Little cesium is noted in the graphite region near the top of the body where the graphite and fuel temperatures were low. Had significant cesium loss from the particles and matrix material occurred, loading in the graphite would be evident. Examination of the graphite adjacent to fuel rod layers 2 through 6 reveals larger cesium losses from the particles. The general profile shape shows the expected qualitative behavior, with larger release having occurred in the middle fuel regions and less release at the cooler regions near the fuel body ends. Note that helium flow was from top to bottom, and fuel in rod layer 1 (bottom) operated at a temperature $\sim 150 \mathrm{~K}$ higher than fuel in rod layer 9 ; this is reflected by the appearance of cesium in graphite adjacent to rod $\mathrm{C} 1$, whereas none was detected near rod C9. Comparison of the axial gamma scans of fuel stack C (Figure 4-3) and the adjacent graphite slice (Fig. 4-5) confirms that higher cesium release occurred from fuel rod regions with high particle loading.

It is interesting to note that fuel rod stack and graphite slice gamma scans do not agree at the interface of fuel rod layers 4 and 5 . It is likely that when the individual fuel rods were reassembled into a composite stack for PIE gamma scanning, fuel rod 5 was inadvertently reversed relative to its position during irradiation.

In order to calibrate the gamma scan results and to provide a quantitative measure of $\mathrm{Cs}-137$ retained in the fuel body, a section of the graphite from slice $C$ was submitted for wet chemistry analysis (see Fig. 4-6). Using the measured activity as a standard, the gamma-scan data were integrated over the length of the slices $\mathrm{A}$ and $\mathrm{C}$ and a composite value of loading in the graphite was calculated. These measurements are important for comparing the observed and predicted cesium loading in the graphite.

\subsubsection{Fuel Matrix Examination. A portion of the shim and matrix material} from fuel rod $\mathrm{C} 4$ was recovered by mechanical disaggregation in a hot cell. Gamma spectrometry measurements revealed a Cs-137 concentration of $33.1 \mu \mathrm{mol} / \mathrm{kg}$. 

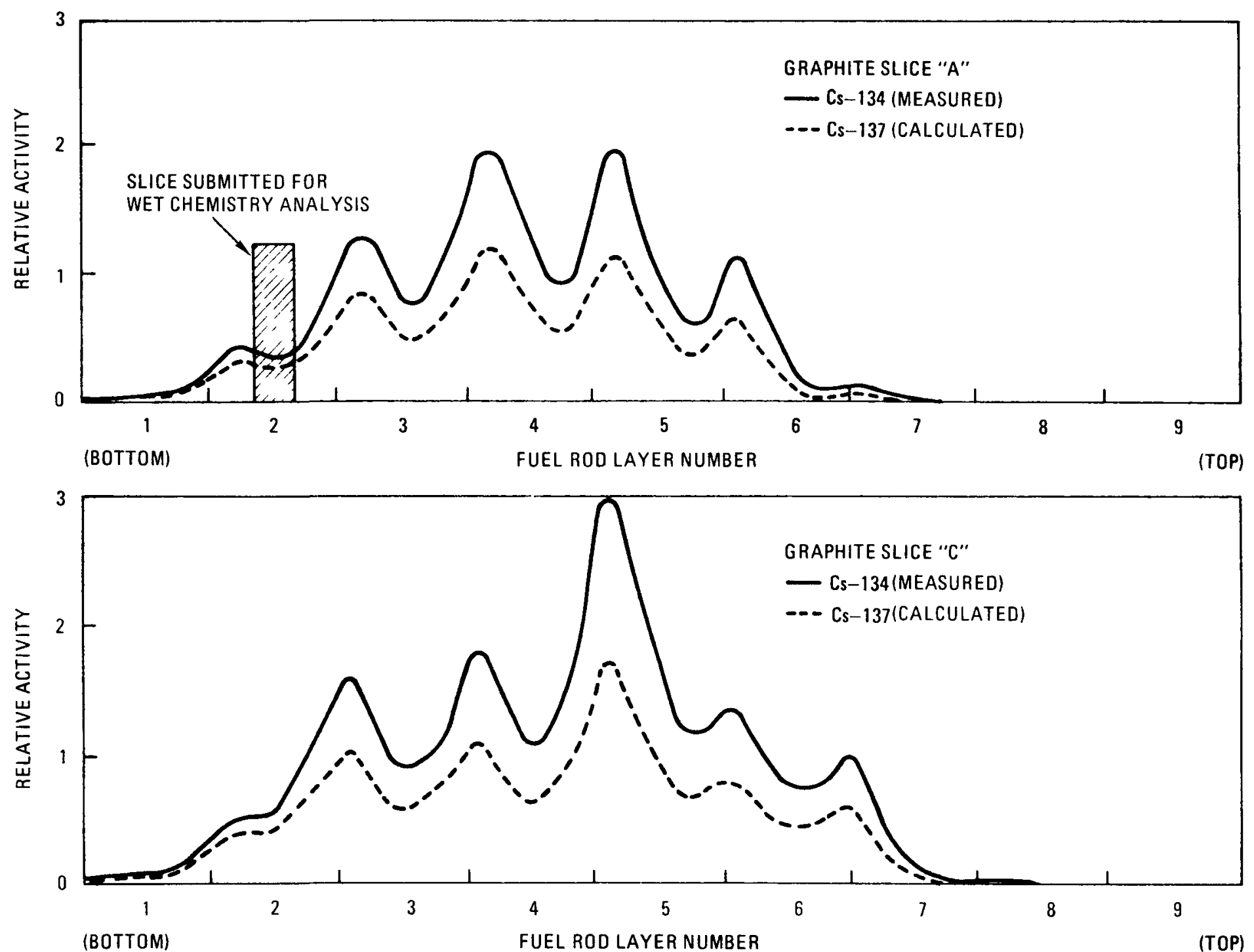

Fig. 4-6. Axial profiles of $\mathrm{Cs}-134$ (measured) and $\mathrm{Cs}-137$ (calculated) in SSL-1 graphite fuel body 
This value has been coupled with cesium loadings in the graphite adjacent to this fuel rod for calculation of the observed partition factor. (Although the mean matrix concentration determined from the gamma count does not yield the true fuel rod surface cesium concentration, it is consistent with models that assume no diffusive holdup of metals in the matrix, i.e., a flat concentration profile exists throughout.) By dividing the matrix concentration by the graphite concentration, a value of $\phi_{(\mathrm{C} 4) \mathrm{Cs}-137}=1.0$ was calculated.

4.3.1.6. Radial Profile. The radial profiles of Cs-134 and Cs-137 in the rod layer 4 fuel rod - coolant hole graphite web were determined at the minimum web thickness by a grinding/counting technique. The web was positioned in a milling machine enclosed by a glove box and sectioned by successive removal of graphite from the surface. The graphite dust from each sample was collected, weighed, and gamma counted to determine cesium activity. The profiles shown in Fig. 4-7 are virtually identical, the activity of Cs-134 being nearly a factor of two larger than that of Cs-137.

\subsubsection{Circuit Components PIE}

Portions of the primary coolant circuit downstream of the fuel element were examined to provide a mass balance for cesium in the loop. The quantity of Cs-137 plated out (i.e., deposited) on the outer Inconel tube and graphite plateout sleeves was measured during PIE (see Fig. 3-2).

4.3.2.1. Outer Inconel Tube. The SSL-1 fuel element was positioned within a double-walled Inconel tube. The wall adjacent to the fuel element, referred to as the "inner Inconel tube," was not analyzed by CEA for cesium plateout. FIPERQ code calculations indicated that release to the periphery coolant channels adjacent to this surface (Fig. 3-2) was less than $10 \%$ of the release to the interior fuel element coolant channels.* For the FIPERQ

*The calculation of $10 \%$ release into the coolant from the outer boundary of the fuel element was carried out by (1) increasing the equivalent graphite thickness to a value approximating the average fuel hole - outer boundary coolant channel thickness, (2) using appropriate CEA-calculated temperatures, and (3) reducing the helium mass flow past the graphite surface at the outer boundary. When these changes were introduced, the net release through the outer boundary was computed to be at least an order of magnitude lower than the predicted release through the coolant hole surfaces. 


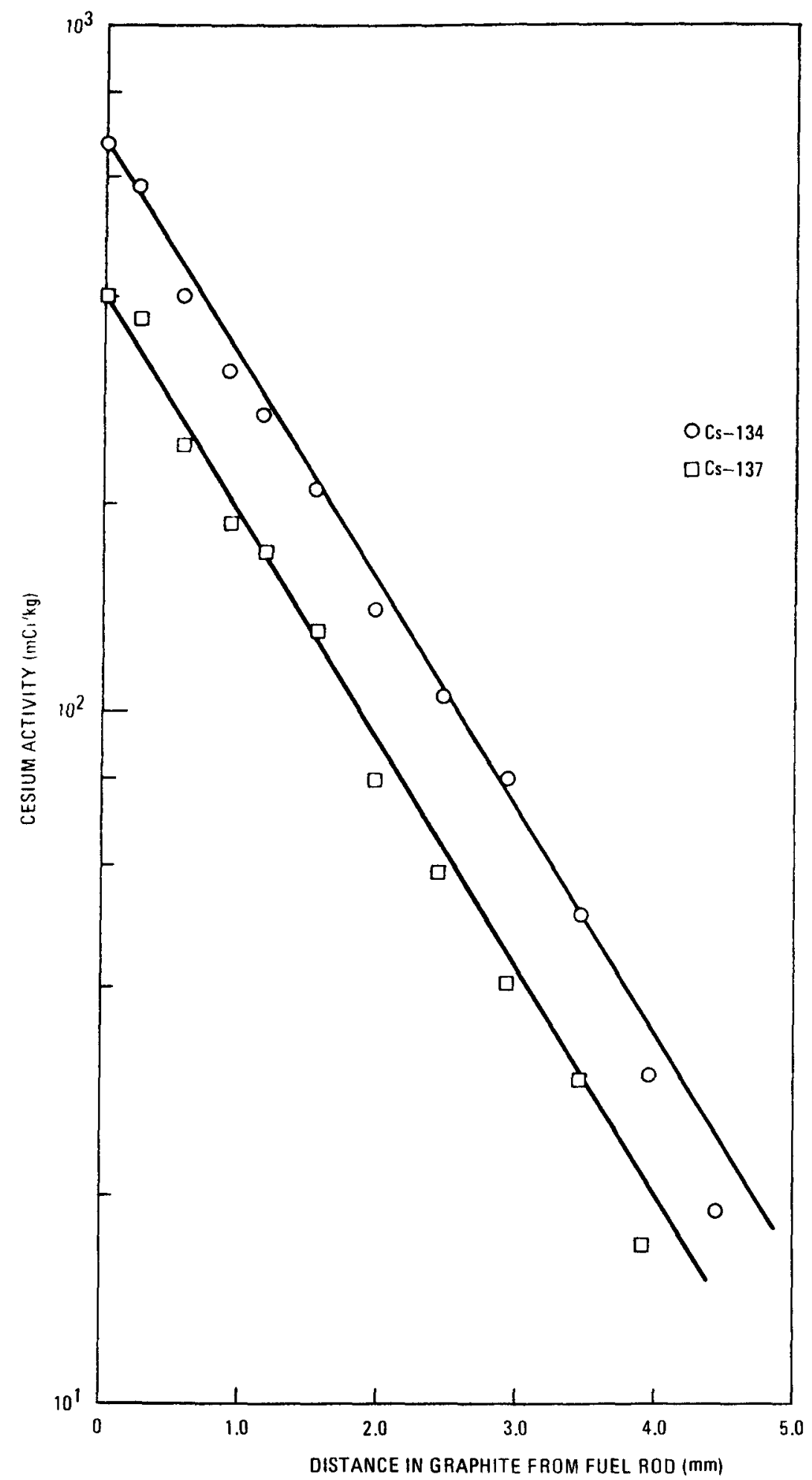

Fig. 4-7. Radial profiles of $\mathrm{Cs}-134$ and $\mathrm{Cs}-137$ in the graphite web adjacent to fuel rod stack $C 4$ in the SSL-1 loop test 
calculations, release to the periphery coolant channels was assumed to be zero.

Cesium plateout along the length of the "outer Inconel tube" was measured out-of-pile. Three 15.0-mm ring sections were cut from the tube at the two ends and the midpoint. The samples were dissolved in an acid solution and gamma counted to determine cesium concentration. This method was used after it was noted that gamma scanning of the empty Inconel tube could not be used to measure cesium concentration due to high background activity of the neutronactivated materials in the tube. The results are shown in Fig. 4-8. The lines shown represent the first-order least squares fit of the data points; the equations for these lines were integrated to yield the total cesium plateout on the tube. Integration over the entire length of the tube yielded $9.47 \mathrm{mCi}$ of Cs-137. These values were summed with other values to provide an estimate of total cesium release. It will be noted that the Cs-134 concentration along the length of the tube exhibited a markedly different behavior than that of Cs-137. Although the concentration of Cs-134 would be expected to be an order of magnitude lower than $\mathrm{Cs}-137$, the reason for a small positive slope of the profile along the tube is not understood. It is possible that due to the low activity present, uncertainties in the counting method precluded accurate measurement of the inventory.

Adjacent to the outer Inconel tube was the "inner Hastelloy tube," which served as one wall of the double-walled pressure casing separating primary helium coolant from the cooling-moderator water of the osiris reactor. Since this component was part of the reactor circuit, no PIE measurements of cesium plateout on the surface were undertaken. As a consequence, it was necessary to estimate this quantity. No temperature measurements were recorded during irradiation for this tube; however, a temperature drop between the outer Inconel tube wall and the Hastelloy tube wall of $150 \mathrm{~K}$ was estimated by the CEA. Since PAD code (Ref. 27) predictions showed that cesium plateout exhibited perfect sink behavior (as opposed to sorption isotherm control), an estimate of inventory was made incorporating the observed axial-dependent plateout on the adjacent Inconel surface and the longer length of Hastelloy tube. This provided a calculated cesium inventory of $10.8 \mathrm{mCi} \mathrm{Cs-137}$. 

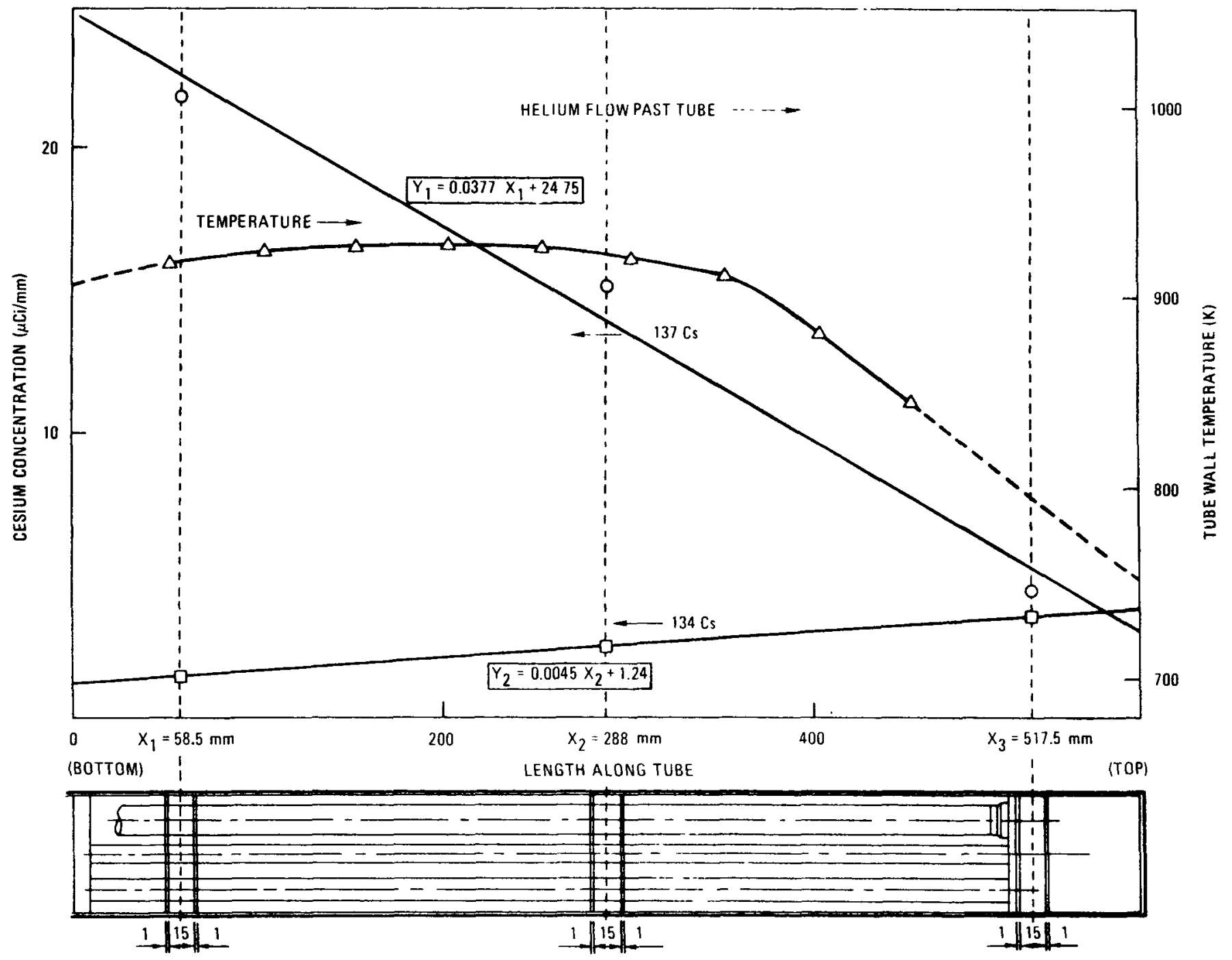

Fig. 4-8. Axial profiles of $\mathrm{Cs}-134$ and $\mathrm{Cs}-137$ and calculated temperatures along the length of the "outer Incone1 tube" of the SSL-1 loop test 
4.3.2.2. Graphite Plateout Sleeve. As noted previously, two graphite sleeves were positioned in the primary coolant circuit downstream of the fuel element and Inconel tube. These were designed to absorb condensible fission products on the high surface area graphite.* The inventory of Cs-137 in the sleeves, $0.32 \mathrm{mCi}$, was measured by sectioning the sleeves and gamma counting the graphite dust.

No cesium was detectable by gamma scanning the metal surfaces downstream of the plateout sleeves.

4.3.2.3. Total Cesium Release. Since FIPERQ calculates the quantity of fission metal released to the coolant channels, measurement of the total cesium in the loop downstream of the fuel element provided a means of calibrating the code. This is the single most important measure of cesium behavior derived from PIE measurements for this analysis. Table 4-9 presents the summary of cesium location and concentrations in the primary circuit. It should be noted that one of the major contributors to the total release (inventory on the Hastelloy tube surface) is an estimated quantity.

*It should be noted that far less cesium was sorbed in the sleeves than had been expected. It is likely that most of the cesium in the primary coolant plated out on the metal surfaces upstream of the plateout sleeve prior to reaching the sleeve graphite surfaces. 
TABLE 4-9

SUMMARY OF Cs-137 RELEASE FROM THE SSL-1 (mCi)

\begin{tabular}{lr}
\hline & ${ }^{(a)}$ \\
Inner Inconel tube (neglected) & 9.47 \\
Outer Incone1 tube (measured) & 10.84 \\
Inner Hastalloy tube (estimated) & 0.32 \\
$\begin{array}{l}\text { Graphite plateout sleeve (measured) } \\
\text { Biological shielding and other } \\
\text { downstream components (neglected) }\end{array}$ & 0 \\
\hline & 20.6 \\
\hline
\end{tabular}

(a) Neglected (see Section 4.3.2.1). 


\section{ANALYSIS OF DATA AND DESIGN METHODS VERIFICATION}

This chapter discusses the means used to compare predicted and measured fission product behavior in SSL-1 and provide verification of reference fission product design methods.

\subsection{FISSION METAL RELEASE}

Meaningful comparison of predicted and observed fission metal behavior can be carried out when the following input are well defined:

1. Fission product source.

2. Fue1 and graphite temperatures.

3. Integrated fission metal plateout downstream of the fuel.

4. Reference input data describing metal diffusivity in fuel particle kernel and coating materials, metal diffusivity in graphite, and appropriate sorption isotherms for matrix material and graphite.

The selected input for FIPERQ analysis of cesium release from SSL-1 are reviewed below.

\subsubsection{Source}

SSL-1 was designed as a fuel performance test. As such, a known source of fission metals, i.e., bare kernels, was not included in the fuel element. The lack of a well defined source proved to be one of the most troublesome 
aspects of the cesium analysis. To carry out FIPERQ calculations, it was necessary to define the source strength. This was done in three ways:

1. By defining the time-dependent particle failure fractions and the fractional release of cesium from fafled oxide particles.

2. By assuming total release of cesium from failed oxide particles.

3. By assigning a cesium release fraction derived from the observed axial loading of $\mathrm{Cs}-137$ in the fuel element graphite.

5.1.1.1. Particle Failure Fractions and Fractional Cesium Release. The EOL fraction of broken fertile particles was assumed to be zero, as discussed in Section 4.3.1.1. The average EOL fissile particle failure fraction was calculated to be $23 \%$. Time varying values at each rod layer were presented in Table 4-6 (Section 4.3.1.1). Having defined the time-dependent fissile and fertile failure fractions, it is necessary to estimate the fractional cesium release from failed particles. The following assumptions were used:

1. No cesium was released from intact TRISO $(8 \mathrm{Th}, \mathrm{U}) \mathrm{O}_{2}$ fissile or $\mathrm{ThO}_{2}$ fertile particles. This assumption is used in HTGR design calculations of cesium release (Ref. 15).

2. No significant heavy-metal contamination existed in the coatings of SSL-1 fuel particles or the matrix material used in the rods. This assumption was verified by preirradiation measurements (Section 4.1.1).

3. Fractional release of cesium from failed oxide particles was defined using the reference design assumption of diffusive and recoil release upon failure, calculated using the COPAR (COated PARticle Release) code (Ref. 28). Recoil results in the direct release of a small fraction of fission product atoms formed within the kernel. The fractional release of each isotope is dependent upon the radius of 
the kernel and the mass of the isotope. Since the recoil range of Cs-137 (6 $\mu \mathrm{m})$ is short compared to the buffer and coating thickness, no recoil release occurs from intact coated particles. However, when particle failure occurs, cesium atoms recoiled directly into the buffer can subsequently be rapidly released. Diffusion of fission metal atoms is a thermally activated process and the extent of cesium release from particles is dependent upon the temperature of irradiation. At low temperature, where diffusive release is negligible, release of fission products from failed particles is controlled by recoil release; at high temperatures, diffusive release becomes rate controlling. The recoil release fraction is dependent upon the mean recoil distance of the isotope of interest in the kernel material and the kernel radius (Ref. 20):

$$
F_{\text {recoil }}=3 / 4 \frac{\rho_{i}}{r}-\frac{1}{16}\left(\frac{\rho_{i}}{r}\right)^{3},
$$

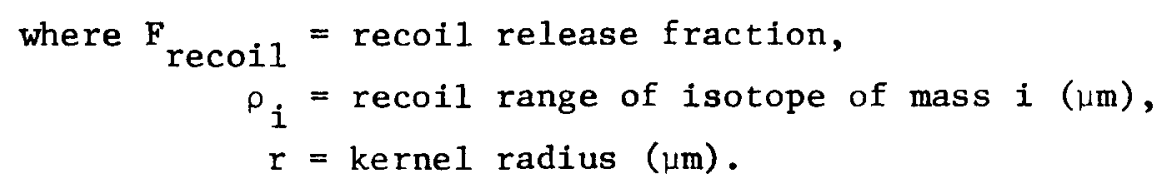

For the particles irradiated in SSL-1, $\rho_{\mathrm{Cs}-137}=6 \mu \mathrm{m}, \overline{\mathrm{r}}=255 \mu \mathrm{m}$, and the calculated recoil release fraction is 0.018 .

The fractional diffusive release was evaluated using the expression for the diffusion coefficient of cesium in oxide kernels supplied in the summary by Myers and Bell (Ref. 3):

$$
\mathrm{D}=\mathrm{D}_{\mathrm{o}} \exp (-\mathrm{Q} / \mathrm{RT}),
$$

$$
\text { where } \begin{aligned}
D & =\text { diffusion coefficient }\left(\mathrm{m}^{2} / \mathrm{s}\right), \\
D_{0} & =\text { constant }=2.38 \times 10^{-10}\left(\mathrm{~m}^{2} / \mathrm{s}\right), \\
Q & =\text { constant }=268,300(\mathrm{~J} / \mathrm{mol}-\mathrm{K}), \\
\mathrm{R} & =\text { gas constant }=8.314(\mathrm{~J} / \mathrm{mol}), \\
\mathrm{T} & =\text { temperature }(\mathrm{K}) .
\end{aligned}
$$


A diffusive release fraction of $1 \%$ was calculated at the peak fuel temperature (rod layer 4) of $1523 \mathrm{~K}$, providing a total calculated release from failed particles in rod layer 4 of $2.8 \%$. when the contribution from recoil was included. This value is significantly less than the observed fractional cesium releases of $17 \%, 21 \%$, and $31 \%$ noted for three failed fissile particles detected in fuel at this location during PIE gamma scans (see Table 4-7). The large discrepancy between predicted and observed release is difficult to explain; however, it is possible that when the particle coatings failed, the kernel also underwent fracture or degradation, resulting in higher than expected releases. (Equation 5-2 is applicable to intact kernels only.)

5.1.1.2. 100\% Fractional Release of Inventory From Failed Particles. Since preliminary calculations showed that predicted release was significantly underpredicted when using the assumption discussed in the previous section, the more conservative assumption of total cesium release from failed oxide particles was used. While this is not felt to be a true representation of the release behavior, it does provide an upper bound to predicted cesium release from particles with falled coatings. The particle failure fractions derived previously were used with this assumption.

\subsubsection{Fractiona1 Release Defined by Axial Cesium Loading in Graphite. A} third estimate of the cesium source was derived from axial and radial gamma scans of the fuel element graphite. The measured loading of Cs-134 and the calculated loading of Cs-137 were presented in Fig. 4-6 (Section 4.3.1.4). The cesium source at each rod layer was established by equating the FIPERQpredicted and "observed" Cs-137 loadings. It is worth noting that the use of this method underestimates the source term in the hotter fuel regions because some cesium does diffuse through the graphite into the coolant at the fuel body temperatures present in the axial center of the element. This effect is felt to be small due to the relatively short duration of the experiment. 


\subsubsection{Fuel and Graphite Temperatures}

Temperatures used as input to FIPERQ were calculated by the CEA using (1) measured helium coolant inlet and outlet temperatures, (2) operational fuel element temperatures measured with three thermocouples positioned within the graphite body, and (3) thermal analysis codes. The mean temperatures shown in Table 4-2 are accurate to within $\pm 40 \mathrm{~K}$.

\subsubsection{Integrated Fisston Metal Release}

Accurate measurement of the integrated metal release is required to "calibrate" the final release numbers provided by FIPERQ. Table 4-9 (Section 4.3.2.3) presents the summary of cesium location and concentrations in the primary circuit. It should be noted that the major contributor to the total release (inventory on the Hastelloy tube surface) is an estimated quantity.

\subsubsection{Reference Input Data}

A11 reference input used in this analysis was taken from the summary work of Myers and Bell (Ref. 3). These data included cesium diffusivity in oxide kernels and $\mathrm{P}_{3}$ JHAN graphite and cesium vapor pressure over GA matrix material and $P_{3}$ JHAN graphite.

\subsubsection{Results and Discussion}

The release at each rod layer was calculated with FIPERQ using the three different source terms. The summed results, shown in Table 5-1, provide a comparison of predicted and measured release. (Representative FIPERQ output is presented in Appendix A.) Use of the source term derived from observed particle failure fractions and estimated cesium release from oxide kernels provides a release that is significantly less than that observed. The predicted axial loading of Cs-137 in the graphite fuel element is shown in Fig. 5-1. Note that the loading in this figure has been 
TABLE 5-1

COMPARISON OF PREDICTED AND MEASURED(a) Cs-137 RELEASE FROM THE SSL-1 LOOP

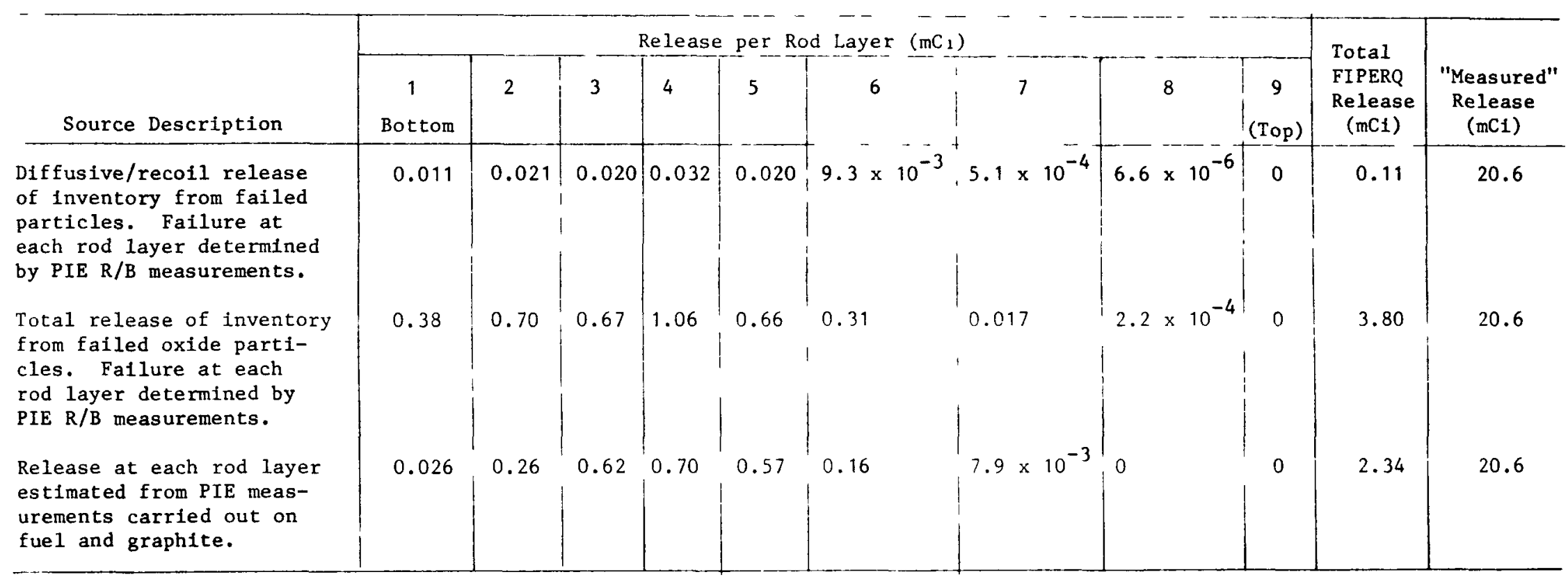

(a) The measured release includes a calculated contribution equal to $10.84 \mathrm{mCi}$ (see Table 4-9). 


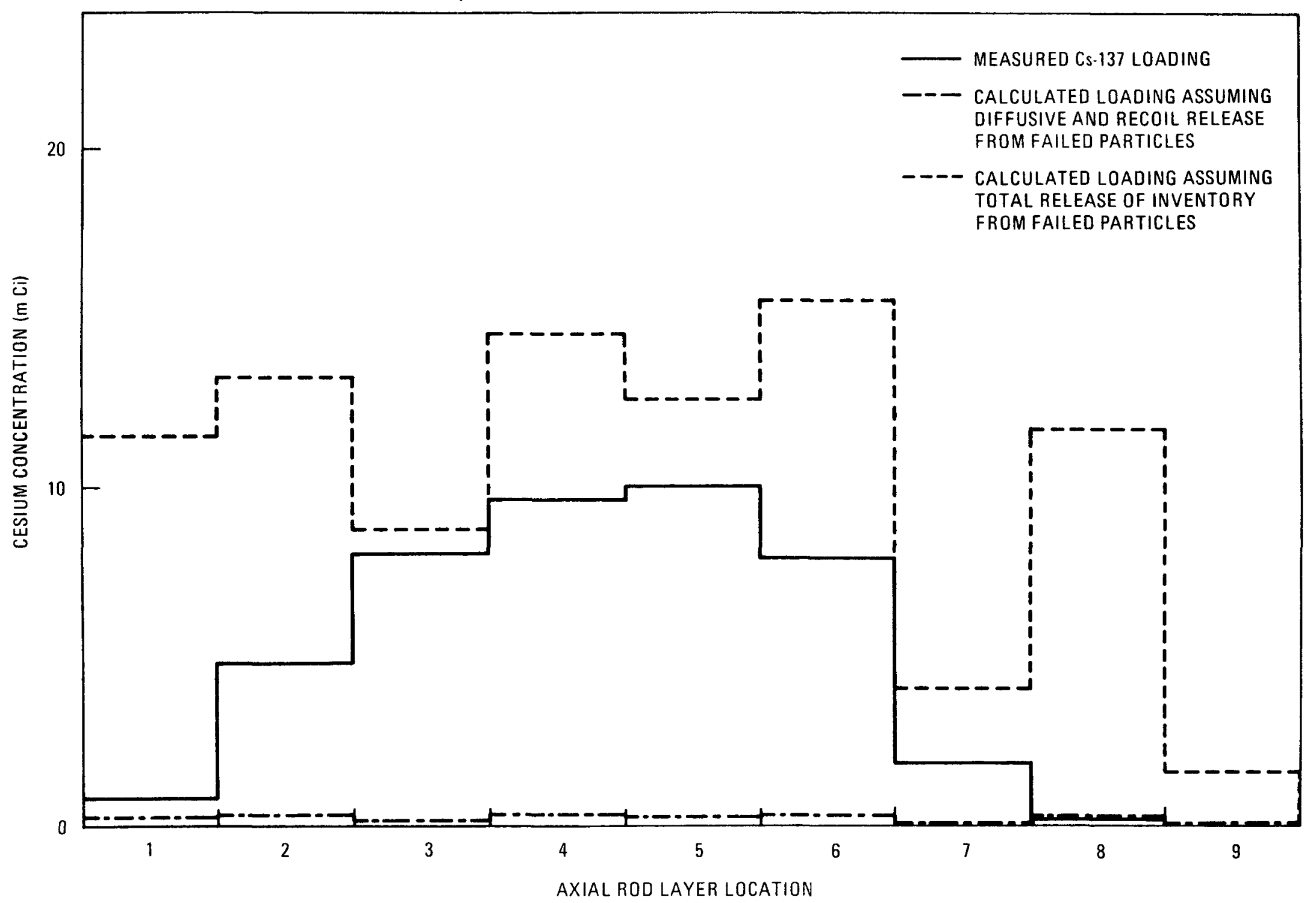

Fig. 5-1. Predicted and measured Cs-137 loading in the SSL-1 fuel body 
averaged over discrete rod layers since this is the smallest length modeled by FIPERQ in this study. From these results, it is apparent that the use of a source term obtained using near-reference methods does not provide adequate modeling of the observed cesium behavior in SSL-1.

A review of the assumptions used for estimating the above source indicates that cesium release from oxide kernels has been inadequately modeled. This is borne out by the results in Table 4-6, wherein $17 \%, 21 \%$, and $31 \%$ cesium loss from failed particles was observed. This is significantly larger than $2.8 \%$ predicted with the COPAR code. The early failure of SSL-1 fissile particles during irradiation indicates that the fissile particles were not representative of normal HTGR fuel. It is possible the oxide kernels in the failed particles underwent degradation that permitted higher than expected cesium releases. However, the limited PIE of the fuel particles did not reveal any significant changes in particles with failed coatings.

Since the source based on diffusive and recoil release did not provide an adequate representation of cesium behavior, the source based on the assumption of total cesium release from failed oxide particles was used. The results in Table 5-1 show that the total release is more closely modeled, although still significantly underpredicted. However, the axial loading of cesium shown in Fig. 5-1 does not correlate well with that measured from the gamma scans. Too much cesium release is ascribed to fuel at the ends of the fuel body, as demonstrated by the significant overprediction of loading in these regions. When the predicted and observed loadings in the graphite are matched, as was done using the third estimate of the source, predicted release was a factor of 29 less than that measured. In view of the lack of correlation between calculated and observed data when the first two source terms were used, a source based on axial cesium loading was used in the analyses discussed below.

The radial profile of Cs-137 in the graphite web at rod layer 4 shows good agreement with the observed profile shape, as demonstrated in Fig. 5-2. The overall magnitudes of the profiles, by definition, are in agreement, although some difference can be expected due to the marked inhomogeneity of 


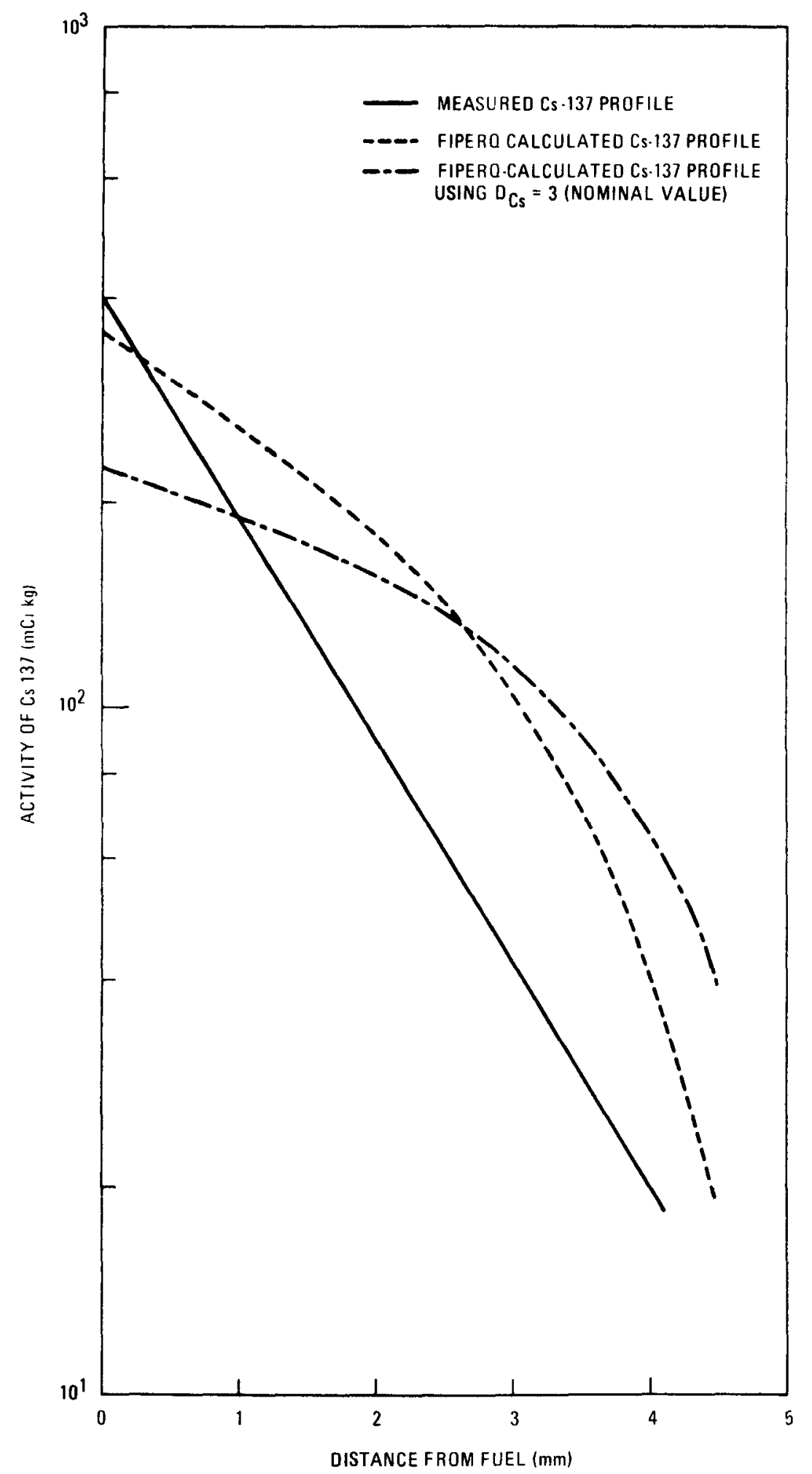

Fig. 5-2. Cesium-137 profile in the graphite web at rod layer 4 of the SSL-1 test 
fuel loading noted at each rod layer location. The similarity of the profiles appears to confirm that the Fick's law model used in FIPERQ adequately models the profile shape of cesium in SSL-1 $\mathrm{P}_{3}$ JHAN graphite. In addition to this comparison, the CEA measured values of the partition coefficient, $\phi$, at rod layer 4 (1.0) compares favorably with the value calculated by FIPERQ (0.73), indicating that the relative values of vapor pressure derived from the cesium isotherms for GA matrix material and $P_{3}$ JHAN graphite provide an acceptable value of $\phi$.

The results of the analysis using the three different source terms can be summarized as follows:

1. The predicted and observed release showed porer than expected correlation. Although uncertainty in the reference input data likely accounted for some of the disparity, the measured cesium behavior was subject to large, essentially unquantifiable uncertainties. This is demonstrated in part by the need to carry out extrapolations and modifications of the measured results in order to make the data suitable for comparison with predictions. Each of these changes introduces uncertainty into the analysis.

2. The fractional cesium release from failed SSL-1 fissile particles was underpredicted by the COPAR code. This is felt to arise in part because of the nonrepresentative nature of the fissile particles irradiated in this test.

3. The Fick's law mode1 used in FIPERQ adequately modeled the single radial profile shape available for analysis. However, no statement regarding the correctness of the predicted cesium loading in graphite can be made due to the large uncertainty in the source.

4. The partition coefficient calculated from PIE measurements was closely modeled by FIPERQ. This provides some assurance that the 
sorption isotherms used in this analysis provide the proper loadings at the temperatures and cesium vapor pressures present in this test.

The impact of uncertainties in the data base were assessed by reviewing the measured or reference values of (1) total cesium release from the element, (2) measured particle failure fraction and cesium loading in graphite, and ( 3 ) cesium diffusivity in graphite.

The measured release of cesium from the element serves as the single most important input for FIPERQ validation. However, aside from the necessity of estimating the loading of cesium on primary circuit components not subject to gamma scans, considerable uncertainty is associated with the data obtained from components subjected to gamma scanning, namely the "outer" Inconel tube (see Section 4.3.2.1). If there were any significant error accompanying any of the three data points collected (Fig. 4-8), the measured slope and hence cesium release would perhaps be significantly different. This comes about because there is no independent verification of cesium release derived from the use of a primary circuit sampling probe. Thus the conclusions of this analysis are totally dependent on the validity of these three measurements. This point is emphasized since the ratio of Cs-134/Cs-137 activities in the fuel body (Figs. 4-6 and 4-7) shows a marked disparity from that observed along the outer Inconel tube. Since the two isotopes are assumed to be released from the fuel body as metallic species, no satisfactory explanation could be found to interpret the differing ratio of activities. It does leave open the possibility that the measured Cs-137 release is too large.

The lack of agreement between predicted and observed behavior may also have arisen due to an underestimate of the source strength. Results from the analysis of the Cadarache Pegase Loop CPL-2 have shown that with a known source term, cesium release is properly predicted only when the loading in graphite predicted by FIPERQ is approximately an order of magnitude larger than that observed (Ref. 29). Since the source term in SSL-1 
was estimated in part by equating observed and predicted cesium loading, the CPL results would indicate that the source term used in SSL-1 was too small. When the loading in graphite predicted by FIPERQ was increased an order of magnitude by increasing the source term an equivalent amount, the predicted release was found to increase by a like amount and to be in close agreement with that observed $(23.4 \mathrm{mCi}$ predicted versus $20.6 \mathrm{mCi}$ observed). While this is a more pleasing agreement, it implies that the source term, i.e., fissile particle failure fraction, was incorrect by an order of magnitude. Such a larger error in the PIE measurements is unlikely. However, the estimate of $3 \%$ failure at EOL may not provide a complete picture for cesium release calculations. The poor performance of the TRISO coated fissile particles, as evidenced from the early rise in ( $R / B)_{10 o p}$ indicates that the SiC coatings on the particles were likely defective. This leaves open the possibility that cesium was released from particles with intact outer PyC coatings and defective or failed SiC coatings. These particles would appear to be intact during metallographic examinations and would show low fission gas release due to the intact outer PyC coating. In addition, the limited number of particles subjected to PIE gamma scans and the minimum uncertainty of this method $(\sim 10 \%)$ would preclude an accurate appraisal of cesium release by the majority of the fuel. The ambiguity associated with the failure fraction highlights the need for known fission metal sources when carrying out validation studies of metallic release codes.

The sensitivity of the total release and the radial profile to changes in the cesium diffusivity in graphite was also studied. FIPERQ sensitivity studies for SSL-1 data revealed that over the relatively short duration of the SSL-1 test, release is highly sensitive to the diffusion coefficient, $\mathrm{D}_{\mathrm{Cs}}$, utilized. Since this value has a large associated uncertainty [10 (1og base 10) $=0.66$ ] (Ref. 19), the value of $D_{C_{S}}$ was increased within this uncertainty range to assess the effect of this change upon release. A three-fold increase in $\mathrm{D}_{\mathrm{Cs}}$ was found to increase the total predicted release by a factor of 5.6. However, the higher diffusion resulted in a predicted radial profile that did not closely agree with the measured profile, as shown in Fig. 5-2. This result would appear to demonstrate that uncertainty in the cesium diffusivity alone cannot account for the large difference noted. 
Although no comprehensive assessment of the validity of FIPERQ could be obtained from analysis of SSL-1 data alone, some requisites for subsequent tests selected for fission metal release code validation studies can be summarized based on the experience with SSL-1:

1. A we11-defined source term must be present, resulting from bare kernels, added heavy metal contamination, or well-characterized time-dependent release from intact BISO particles.

2. A series of metal profile measurements in the graphite fuel body must be obtained to define metal diffusive behavior in different axial locations of the element (hence in different temperature regimes).

3. Metal release to the coolant stream must be calculated using two independent means, i.e., primary coolant sample probes and EOL circuit gamma-scans.

\subsection{FISSION GAS RELEASE}

The half-life dependence of krypton and xenon diffusion in matrix material has been evaluated using in-pile fission gas release data. Values of $\log (R / B)_{i}$ versus the $\log$ of the half-life of isotope $i$ for five krypton nuclides and six xenon nuclides at 25 and 120 EPFD of irradiation are presented in Figs. 5-3 and 5-4, respectively. The data at 25 EFPD were selected for analysis since this was the earliest time at which results for all nuclides were available. The latter data were collected just prior to shutdown of the test. A summary of the salient results from these two plots is presented in Table 5-2.

The half-life dependence of krypton diffusion is seen to be slightly greater than 0.5 , the expected value using GA reference design methods, at both time points; however, this value is within the scatter band of data reported by Myers and Bell (Ref. 4). The similarity of the values at the two time points confirms that no apparent changes affecting fission gas release took place in the fissile particles during irradiation up to 


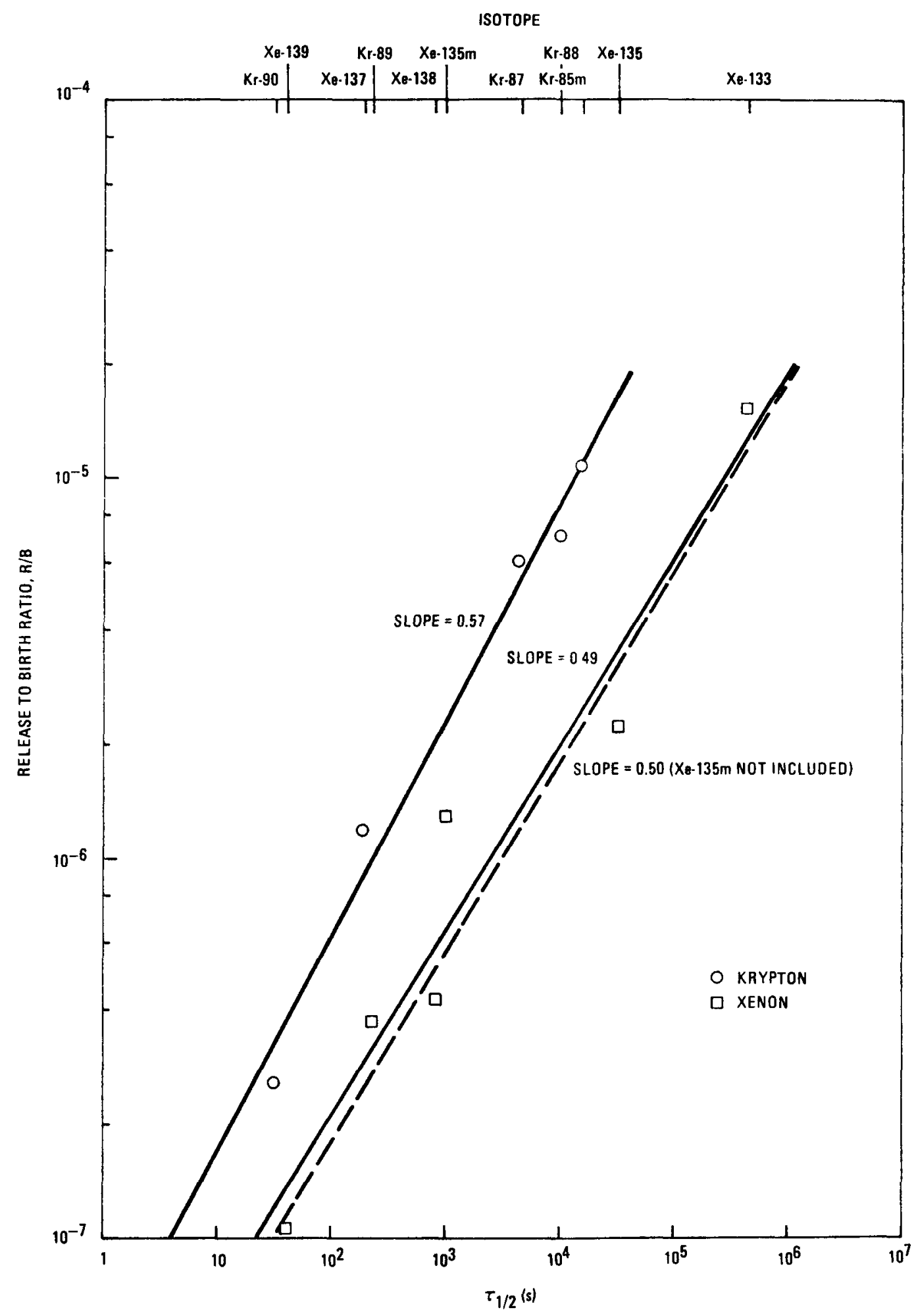

Fig. 5-3. Plot of $\log (\mathrm{R} / \mathrm{B})_{i}$ versus $\log \tau_{i} 1 / 2$ for krypton and xenon isotopes released from the SSL-1 fuel element at 25 EFPD 


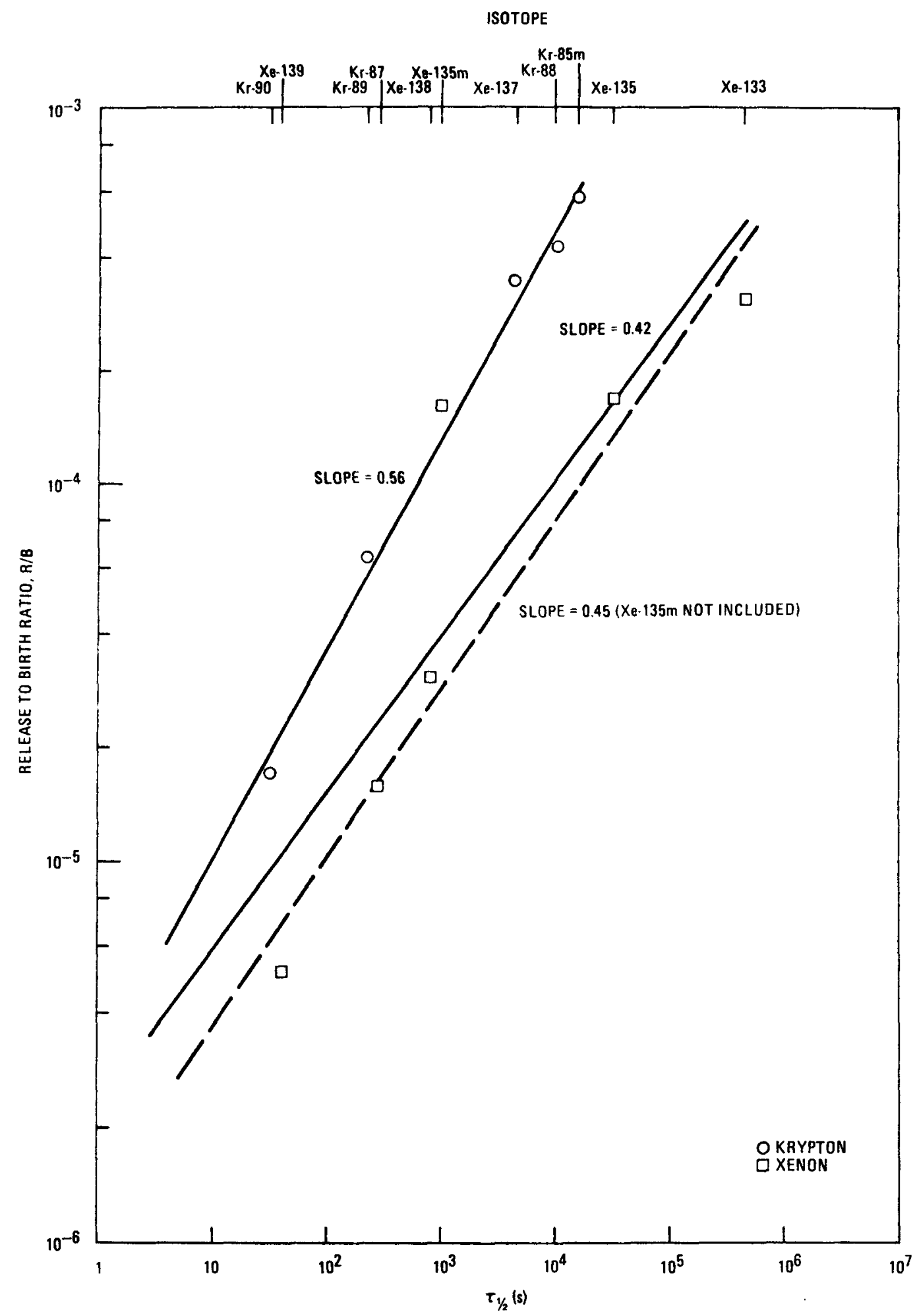

Fig. 5-4. Plot of $\log (R / B)_{i}$ versus $\log \tau_{i} 1 / 2$ for krypton and xenon isotopes released from the SSL-1 fuel element at 120 EFPD 
TABLE 5-2

SUMMARY OF DATA ON HALF-LIFE DEPENDENCE OF Kr AND Xe DIFFUSION DERIVED FROM THE SSL-1 LOOP

\begin{tabular}{|c|c|c|}
\hline & \multicolumn{2}{|c|}{$\begin{array}{c}\text { Time of In-Pile R/B } \\
\text { Measurement }\end{array}$} \\
\hline & 25 EFPD & 120 EFPD \\
\hline $\begin{array}{l}\text { Half-life dependence } \\
\text { of } \mathrm{Kr} \text { diffusion in } \\
\text { fuel rods }\end{array}$ & 0.57 & 0.56 \\
\hline $\begin{array}{l}\text { Half-life dependence } \\
\text { of Xe diffusion in } \\
\text { fuel rods }\end{array}$ & $0.49(0.50)^{(a)}$ & $0.42(0.45)^{(a)}$ \\
\hline $\begin{array}{l}\text { Expected half-life } \\
\text { dependence using } \\
\text { reference GA methods }\end{array}$ & 0.50 & 0.50 \\
\hline $\mathrm{A}_{\mathrm{Kr}} / \mathrm{A}_{\mathrm{Xe}}{ }^{(\mathrm{b})}$ & $3.9(4.4)^{(a)}$ & $4.0(5.4)^{(a)}$ \\
\hline $\begin{array}{l}\text { Expected value at } \\
1473 \mathrm{~K}(\mathrm{c})\end{array}$ & $\sim 3$ & $\sim 3$ \\
\hline
\end{tabular}

(a) These are values derived without the inclusion of $\mathrm{Xe}-135 \mathrm{~m}$ data.

(b) $\mathrm{A}_{\mathrm{Kr}} / \mathrm{AXe}$ represents the ratio of the fractional release of krypton to that of xenon for isotopes of equal half-1ives (hypothetical) of 1 hour.

(c) Ref. 4 . 
7.3\% FIMA. These findings are confirmed by the data on xenon release. In this instance, two estimates of the half-life dependence are presented due to uncertainty associated with the measured value of $\mathrm{Xe}-135 \mathrm{~m}$; at both time points the Xe-135m release shows significant deviation from the expected behavior. Because of this uncertainty, the least-squares fit of the xenon data has been carried out with and without the Xe-135m data. The inclusion or deletion of these data has only a small impact on the calculated slope of the data, as shown in Table 5-1. However, the effect is much larger when the value of $\mathrm{A}_{\mathrm{Kr}} / \mathrm{A}_{\mathrm{Xe}}$, the fractional release of krypton to xenon for hypothetical isotopes with half-lives equal to $1 \mathrm{~h}$, is calculated. Based on data in Ref. 4 and the assumed volume-average fuel temperature of $\sim 1473 \mathrm{~K}$, a ratio of $\sim 3$ would be predicted. The results in Table 5-1 show that the measured values are higher than expected, particularly when measurements of $\mathrm{Xe}-135 \mathrm{~m} \mathrm{R} / \mathrm{B}$ are not included. No explanation of this difference is offered; however, it is worth noting that a large uncertainty exists in volume-average fuel temperature (although values greater than $1573 \mathrm{~K}$ are unlikely) and the $\mathrm{A}_{\mathrm{Kr}} / \mathrm{A}_{\mathrm{Xe}}$ ratio is very sensitive to the krypton and xenon activation energies used as input in the design method. The values may differ for fuel rods cured-in-bed, from which the data in Ref. 4 are derived, and fuel rods curedin-place. Eighteen of 27 fuel rods in SSL-1 were cured by the latter method. Overall, the R/B data from SSL-1 provide confirmation that the fission gas release model used in the design method provides an accurate description of noble gas diffusion in matrix materials. The agreement between predicted and observed behavior is acceptable in view of the uncertainty associated with both data sets.

An analysis of the graphite sectioning data presented in Fig. 4-6 revealed that gaseous precursors did not play an important role in establishing the profiles of $\mathrm{Cs}-134$ and $\mathrm{Cs}-137$ in the graphite web. This can be visualized after reviewing the decay and activation schemes for these isotopes:

$$
\begin{aligned}
\mathrm{Xe}-133(5.2 \mathrm{~d}) \rightarrow & \mathrm{Cs}-133(\text { stable })+\gamma \\
& \mathrm{Cs}-133+\mathrm{n} \rightarrow \mathrm{Cs}-134(2.06 \mathrm{y}) \\
\mathrm{Xe}-137(3.84 \mathrm{~m}) \rightarrow & \mathrm{Cs}-137(30 \mathrm{y})
\end{aligned}
$$


If the holdup time, $\mathrm{T}_{\mathrm{h}}$, of xenon in graphite were $<30 \mathrm{~s}$, the decay of both isotopes would yield flat precursor profiles of differing magnitude (Cs-137 being greater than Cs-134). Since the isotope profiles show similar decreasing concentration toward the outer boundary of each web, the precursor contributions are seen to be insignificant. If a longer holdup time were to exist, $30 \mathrm{~s}<\mathrm{T}_{\mathrm{h}}<650 \mathrm{~s}$, the decay of Xe-137 would provide a precursor profile that was not flat but decreasing toward the outer web boundary; the Xe-133 precursor contribution would still be flat due to its much longer half-1ife. However, if Xe-137 decay did provide a measurable contribution to the profile, the $\mathrm{Cs}-137$ and $\mathrm{Cs}-134$ profiles would be disparate, a result not found during the sectioning. Analogous reasoning can be used to show that at $\mathrm{T}_{\mathrm{h}}>650 \mathrm{~s}$ the precursor contribution of $\mathrm{Xe}-133$ is likewise insignificant. Thus, the combination of Cs-134 and Cs-137 profiles that are both identical and decreasing toward the outer web boundary indicates that metallic diffusion is the controlling release mechanism. This is an important finding since FIPERQ does not model gaseous precursor contributions to release. 


\section{ACKNOWLEDGMENTS}

The authors are indebted to personnel at the Commissariat a 1'Energie Atomique (CEA) for collection and interpretation of operational and PIE data, to D. P. Harmon for direction of the GA fuel fabrication effort and early interpretation of PIE results, to $K$. Mysels for measurements of cesium diffusivity in $P_{3}$ JHAN graphite, to $H$. G. Staley for measurement of cesium sorption isotherms, to B. F. Myers for helpful interpretation of PIE data, and to J. T. Ganley and M. H. Merrill for data transmittals and translations. 


\section{REFERENCES}

1. Jensen, D. D., et al., "Planning Guide for the Validation of Fission Product Transport Codes," ERDA Report GA-A13386, Genera1 Atomic Company, April 15, 1975.

2. Myers, B. F., and W. E. Bell, "Strontium Transport Data for HTGR Systems," USAEC Report GA-A13168 (GA-LTR-16), General Atomic Company, December 6, 1974 .

3. Myers, B. F., and W. E. Bell, "Cesium Transport Data for HTGR Systems," DOE Report GA-A13990, General Atomic Company, to be published.

4. Myers, B. F., et al., "The Behavior of Fission Product Gases in HTGR Fuel Material," DOE Report GA-A13723, General Atomic Company, October 1977.

5. Burnette, R. D., W. E. Bell, and N. L. Baldwin, "Fission Product Retention Characteristics of HTGR Fuel," in Proceedings of the International Conference on Nuclear Fuels Performance, British Nuclear Energy Society, London, October 15-19, 1972 Paper 16.

6. Nabielek, H., et al., "Performance Limits of Coated Particle Fuel Part III, Fission Product Migration in HTR Fuel," Dragon Project Report 828, AEE Winfrith, 1973.

7. Brown, P.E., et al., "Metal Fission Product Behavior in HTR $\mathrm{UO}_{2}$-Coated Particle Fuel," Atomic Energy Research Establishment Report AERE-R8065, AERE Harwe11, 1975.

8. Morgan, M. T., H. J. de Nordwall, and R. L. Towns, "Release of Fission Products from Pyrocarbon Coated HTGR Fuel Particles During Postirradiation Annea1s," USAEC Report ORNL-TM-4539, Oak Ridge Nationa1 Laboratory, December 1974.

9. Wallroth, C. F., et al., "Postirradiation Examination of Peach Bottom Fuel Test Element FTE-3," USAEC Report GA-A13004, General Atomic Company, August 15, 1974.

10. Wallroth, C. F., J. F. Holzgraf, and D. D. Jensen, "Postirradiation Examination of Peach Bottom Fuel Test Element FTE-4," ERDA Report GA-A13452, General Atomic Company, July 1977. 
11. Zumwa1t, L. R., and J. S. Phelps, III, "Coupled Fast-Slow Diffusion Mode1 for Metallic Fission Products in Graphite," Trans. Am. Nucl. Soc. 22, 212 (1975).

12. Bryant, E. A., et a1., "Rates and Mechanisms of the Loss of Fission Products from Uranium-Graphite Fuel Materials," Nucl. Sci. Eng. 15, 288 (1963).

13. Haire, M. J., and L. R. Zumwalt, "Cesium Diffusion Coefficients and Other Results From the Analysis of Peach Bottom D13-05 Fuel Element Activity Profiles," USAEC Report Gulf-GA-A12492, Gulf General Atomic, July 1973.

14. Forutanpour, B., and B. Roos, "FIPERX, A FORTRAN V Program for the Solution of One-Dimensional Linear and Non-Linear Diffusion Problems," USAEC Report GA-9904, Gulf General Atomic, September 1969.

15. Alberstein, D., P. D. Smith, and M. J. Haire, "Metallic Fission Product Release from the HTGR Core," General Atomic Report GA-A13258 (GA-LTR-20), May 15, 1975.

16. Vanslager, F. E., "RAD2, A Computer Program for Calculating Fission Product Radioactivities," General Atomic, Division of General Dynamics Report GAMD-6519, 1965.

17. Hudritsch, W. W., "RANDI, A Zero-Dimensional Computer Program for Calculating HTGR Activities," General Atomic Report GA-A14091, March 1977.

18. Haire, M. J., and D. W. McEachern, "Gaseous Radioactivity Levels in the Primary Coolant of an HTGR," General Atomic Report GA-A12946 (GA-LTR-14), October 1, 1974.

19. "HTGR Accident Initiation and Progression Analysis Status Report, Volume V. AIPA Fission Product Source Terms," ERDA Report GA-A13617, General Atomic Company, February 1976.

20. Zumwalt, L. R., E. E. Anderson, and D. E. Gethard, "Fission-Product Retention Characteristics of Certain (Th,U) $C_{2}$ - Graphite Fuels, "General Atomic, Division of General Dynamics Report GA-4551, September 7, 1963.

21. Eichenberg, J. D., et al., "Effects of Irradiation on Bulk Uranium Dioxide," in Fue1 Elements Conference, Paris, TID-7546, 1958.

22. Milstead, C. E., "Sorption Characteristics of the Cesium-Graphite System at Elevated Temperatures and Low Cesium Pressures," Carbon 7, 199 (1969).

23. Dunlap, R. W., and T. D. Gulden, "Diffusion Model for Release of Fission Products from Coated Particle Fuels," Nuc1. Sci. Eng. 32, 407 (1968). 
24. Flügge, S., and K. E. Zimens, "Determination of Grain Size and Dif-

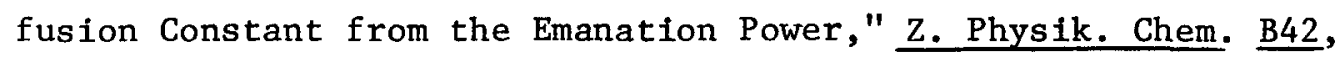
179 (1939).

25. Scott, C. B., D. P. Harmon, and J. F. Holzgraf, "Postirradiation Examination of Capsules P13R and P13S," ERDA Report GA-A13827, General Atomic Company, October 1976.

26. Pointud, M., and P. Chenebault, "Emission of Fission Gases by Failed Coated Oxide Fuel Particles," Nuc1. Tech. 35 (2), 494 (1977).

27. Vanslager, F. E., and L. D. Mea s, "PAD, A Computer Code for Calculating the Plateout Activity Distribution in a Reactor Circuit," Gulf General Atomic Report GA-10460, January 1971.

28. Smith, P. D., et al., "Release of Metallic Fission Products from Multilayered Coated Particles," Nucl. Tech. $\underline{35}$ (2), 475 (1977).

29. "HTGR Fuels and Core Development Program Quarterly Progress Report for the Period Ending August 30, 1977," ERDA Report GA-A14479, Genera1 Atomic Company, September 1977. 
APPENDIX A

SAMPLE FIPERQ CODE OUTPUT 


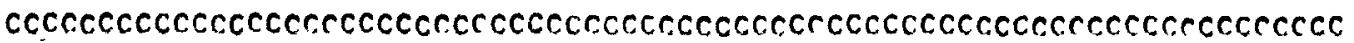

C THIS RIIN IS USEO TO FREDICT THF RFLEASF OF CESIUPA FQUA RUD LAYER 5 OFC

C THF SSL-1 LOOF TEST. THE CESIUM UIFFUSION COEFFICIENT AND SURPTION

C ISOTHERMS HAVE BEEN TAKEN FROM THF REPORT OF MYEPS ANO BELL

C (GA-A13990). AN ESTIMATEO VALUE OF THE CESIUM CUMMULATIVE

C FISSION YIELD OF CESIUM=1.95(-1) IS USED TO INCLUDE THE IMPORTANT

C ISOTOPES $(C 5-133,-135,-137)$ THAT AFEECT LOAOING. THE RESULTS

C NEED TO GE MULTIPLIEO BY 0.33 TO PROVIUE CS-137 RELEASE.

C THE FISSILE FAILURE HAS BEEN DETERMINED EMPIRICALLY FROM PIE

C THE FISSILE FAILURE HAS BEEN DETERMINFD EMPIRICALLY FROM PIE
C MEASUREMENTS. THE FERTILE FAILURE IS IERO.
CCCCCCCCCCCCCCCCCCCCCCCCCCCCCCCCCCCCCCCCCCCCCCCCCCCCCCCCCCCCCCCCCCCCCCCC

BASIC DIFFUSIONEOUATION

OC/OT = $\because$ IOUC/ORI/OR + S - LAMBDANC - VMP/RT

WHERE CECONCENTRATION, TETIME, DEDIFFUSION COEFFICIENT, RADISTANCE, SESOURCE, LAMBOA-DeCáY CONSTANT, V-TRANSVEASE FLOW VELOCITY, POVAPOR PRESSURE. RTEGAS CONSTANTETEMPERATURE

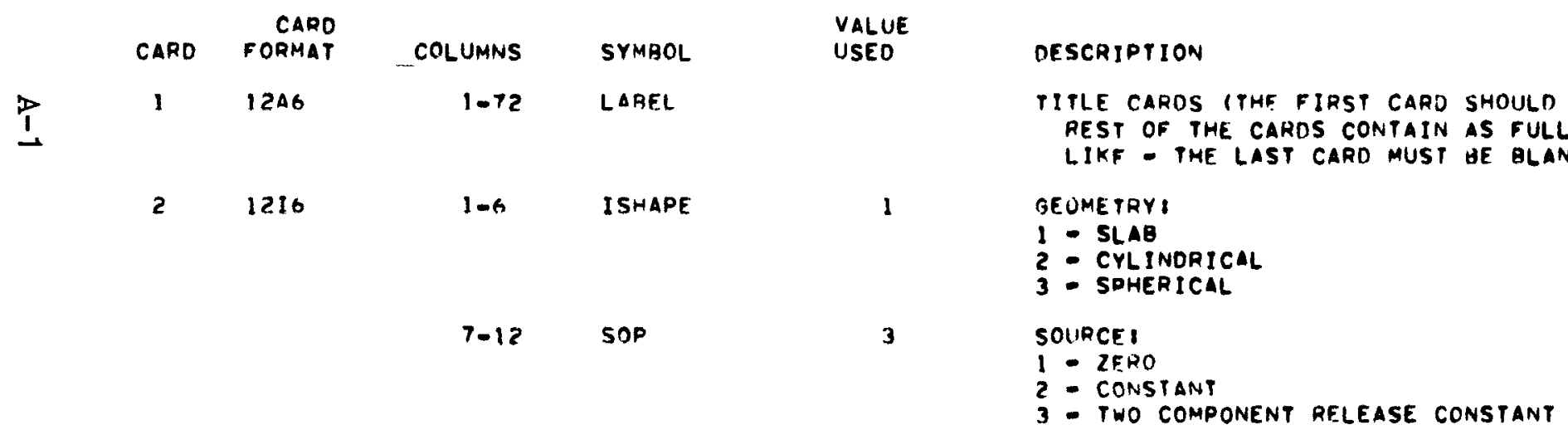

- UNDTEI THE FUNCTIONS PSI AND CHI ARE FUNCTIONS OEFINED GY THE FOLLOWING NONLINEAR INHOMOGENFOUS MIXFO DIRTCHLET AND NEUMAN NUTER BOIINDARY CONOITIONI

$D * C(R, T) /-R+P S I(C, T) \cdot C(R, T)=C H I(T)$

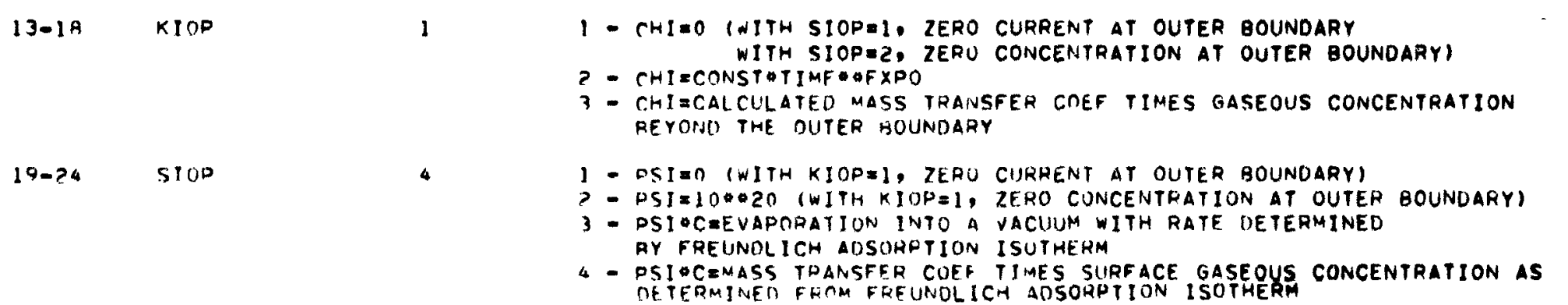


OOOB CS-137 FFLEASE FROR ROU LAYEN 5 OF THE SSL-I IEST OAOOO

\begin{tabular}{|c|c|c|c|c|}
\hline CAKD & $\begin{array}{l}\text { CARD } \\
+ \text { ORMAT }\end{array}$ & COLIIMNS & SYMEOOL & $\begin{array}{l}\text { VALUIE } \\
\text { IISEO }\end{array}$ \\
\hline \multirow[t]{8}{*}{$?$} & & $25-30$ & LFFTHO & 1 \\
\hline & & $31-36$ & NOIIAST & $n$ \\
\hline & & $43-48$ & NME SHP & 52 \\
\hline & & $37-42$ & NUM 150 & 1 \\
\hline & & $49-54$ & NUMAT & 90 \\
\hline & & $55-60$ & NIIMDTP & a \\
\hline & & $61-66$ & FEEOP & 2 \\
\hline & & $67-72$ & VZnP & 1 \\
\hline \multirow[t]{7}{*}{3} & $71 \mathrm{R} . \mathrm{F} 4.0 .416$ & $1-6$ & NVASS & ? \\
\hline & & $7-12$ & NMESHR & 1 \\
\hline & & $13-18$ & PJFEE & 3 \\
\hline & & $19-24$ & NUMD & 2 \\
\hline & & $25-30$ & NIIMIT & 16 \\
\hline & & $31-36$ & NTLOAN & 4 \\
\hline & & $37-42$ & PLOT & 0 \\
\hline & & $43-4 A$ & $X R A M P$ & n \\
\hline
\end{tabular}

DESCODPION

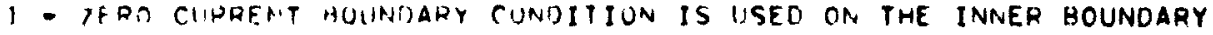
? - IEPO CONCENTHATION GOUNDARY CONIIITION IS USEO ON THE INNER BOUNDARY

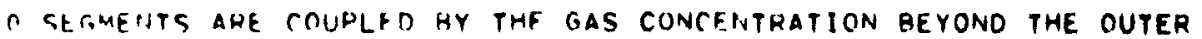
HCUINTARY. THIS IS SEGMENT 1 .

NUMBFR OF MESH POINTS (THE IWO ENO PTS MUST BE INCLUDEO) (SE 52 )

R.JMGEF OF TSOTOPES (2E 4)

NUMAFR OF CALCILATIONAL TIME STEHS TO BE LOADED (SO 100 )

NIIMGFR OF PRINT TIME STEPS TO BE LOADEO (CE 20 )

1 - constant value for the fee concentration ratio

2 - TEMPFRATURE ANO CONCENTRATION DEPENDENT VALUE RASEO ON LANGMUIR - FREUNOLICH ISOTHERMS

1 - TERO FLOW VELOCITY IN THE AXIAL OIRECTION

$?$ - FLOW VELOCITIES \& CHANNEL WIOTHS AT MATERIAL INTERFACES

ARE SPECIFIED FOR EACH INPUT TIME INTERVAL

NIIMAFP OF MESH SIZF VALUES TO BE LOADED (<E52)

NIIMAFP OF INITIAL CONCENTRATION VALUES TO BE LOADEO $(<=52)$

NIIMTEF OF SOHPTION HATIO VALUES TO HE LOADEO (CE 52$)$ IADSORPTION RATIO AT MESH POINT M EOUALS THE RATIO OF THE CONCENTRATION ON THF LFFT TO THAT ON THE RIGHT OF TME MESH POINT)

NIJMEFH OF DIFFUISION COEFFICIENT VALUES TO BE LOADED (SA 52)

NUMAFR DF INPUT TIME INTERVALS $(<=100)$

NIMMER OF MESH POINTS AT WHICH TEMPERATURE DATA ARE LOADED ILINEAR

INTERPOLATION OF TEMP BETWEEN SPECIFIED MESH POINTSI

(THF INPER ANI) OIITFR PTS M(IST BE INCLUDED) (<E 52)

- - co not plot results

1 - PLOT CONCENTRATIONI IHICRUMULES/CC) VS OISTANCEICM) AND RELEASE (CURIES) VS TIME (DAYS)

TEMPFDATIHE RAMP IIME FHACTION $(0, \angle 2 X K A M P<=.5)$ 


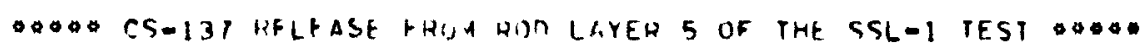

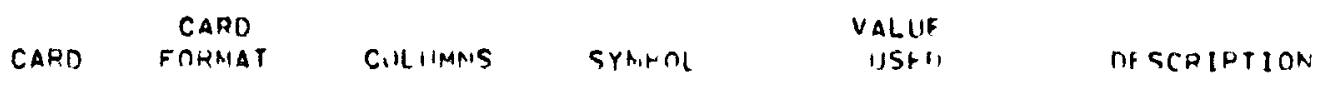

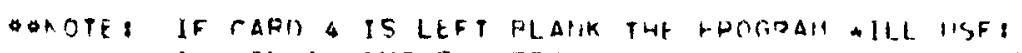

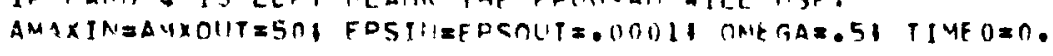

4612.6

$\begin{array}{ll}1-12 & \text { AMAXIN } \\ 13-24 & \text { AMXOIT } \\ 25-36 & \text { EPSIN } \\ 37-48 & \text { EPSOUT } \\ 49-68 & \text { OMEGA } \\ 61-72 & \text { TIMEO }\end{array}$

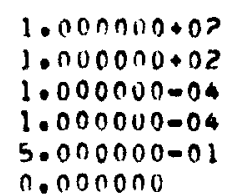

MAXIMUM NIMGER OF INNER ITERATIUNS $1<250$ ) MAXIMUM NUMBFR OF OUTER ITERATIONS $1<=50$ ) CONVERGENCE PARAMETER FOR INNER ITERATIONS CONVERGENCE PARAMETER FOR OUTER ITERATIONS DFLAXATION PARAMETFR $10.5<\triangle O M E G A<=1.01$ IIITIAL TIMF (SFCONOS)

- anotei if supal. leave cafo 5 rlank fxcept fur taasf anh tiarfa,

\begin{tabular}{|c|c|c|c|c|}
\hline 5 & $6+12.6$ & $\begin{array}{l}1-12 \\
13-24 \\
25-36 \\
37-48 \\
49-60 \\
61-72\end{array}$ & $\begin{array}{l}\text { TEASE } \\
\text { TIAREA } \\
\text { AFERM! } \\
\text { BFERM! } \\
\text { AFFRMO } \\
\text { BFERMO }\end{array}$ & $\begin{array}{l}1.000000+03 \\
7.225000+01 \\
0.000000 \\
1.000000=04 \\
4.040000=01 \\
1.000000=04\end{array}$ \\
\hline 6 & $G E \ 2.6$ & $1-12$ & LAMDA $(1)$ & $7.270000-10$ \\
\hline $7 A$ & $6 E 12.6$ & $\begin{array}{l}1-12 \\
13-74 \\
25-36 \\
37-49 \\
49-60 \\
61-72\end{array}$ & 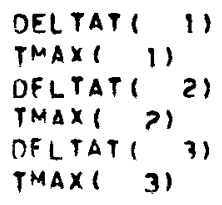 & $\begin{array}{l}1.000000+00 \\
1.000000+01 \\
1.000000+01 \\
4.000000+01 \\
6.000000+01 \\
3.600000+03\end{array}$ \\
\hline 78 & & $\begin{array}{l}1-12 \\
13-24 \\
25-36 \\
37-6 A \\
49-60 \\
61-72\end{array}$ & 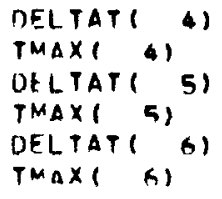 & $\begin{array}{l}3.600000+103 \\
4.320000+04 \\
4.320000+04 \\
2.160000+05 \\
1.000000+00 \\
? .160100+05\end{array}$ \\
\hline $7 C$ & & $\begin{array}{l}1-12 \\
13-24 \\
25-30 \\
37-48 \\
49-60 \\
61-72\end{array}$ & $\begin{array}{l}\text { DELTAT ( T) } \\
\text { TMAXI TI } \\
\text { DFLTAT, A) } \\
\text { TMAXY A) } \\
\text { TFLTAT( Q) } \\
\text { TMAXI 9) }\end{array}$ & $\begin{array}{l}1.000000+01 \\
2.160600+05 \\
6.000000+01 \\
1.196000+05 \\
3.600000+03 \\
2.592000+05\end{array}$ \\
\hline 7i) & & $\begin{array}{l}1-17 \\
13-24 \\
25-76 \\
37-49\end{array}$ & 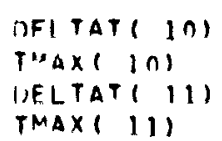 & $\begin{array}{l}4.320000+04 \\
7.3440110+05 \\
1.000000+00 \\
7.344100+05\end{array}$ \\
\hline
\end{tabular}

NOHMALIZATION TFMPEHATURE FOR DIFF CDEF ANO SOURCE (OEG. C) TOTAL OUTER BOUNDARY SURFACE AREA (SOCM)

a - FOR INNER FERMI FUNCTION. DISTANCE TO INNER BOUNOARY OF SOURCE (CMI - FOR INNER FERMI FUNCTION (CM)! $1.1(1 . \cdot \operatorname{EXP}((A-X) / B))$

A - FOR OUTER FFRMI FUNCTION. DISTANCE TO OUTER BOUNDARY OF SOURCE (CM) B - FOR OUTER FERMI FUNCTION (CM): 1. $1(1$. EXP $((X-A) / B))$

DECAY CONSTANT FOR ISOTOPE I (I/SEC)

CALCILATIONAL TIME STEP 1 (SECONDS) I AST TIME TO USF CALCULATIONAL TIME SIEP 1 (SECONOS FROM TIMEOI CALCIILATIONAL TIME STEP 2 (SECONDS) I AST TIME TO USF CALCIJATIONAL TIME STEP 2 (SECONDS FROM TIMEO) CAI CULATIONAL TIME STEP 3 ISECONDS) LAST TIME TO USE CALCULATIONAL IIME STEP

3 (SECONOS FROM TIMEO) CALCILLATIONAL TIME STEP A (SECONDSI LAST TIME TO USE CALCULATIONAL TIME STFP \& (SECONOS FROM TIMEO) CALCULATIONAL TIME STEP 5 (SECONDS) LAST TIME TO USE CALCULATIONAL TIME STEP 5 (SECONOS FROM TIMEO) CALCILATIONAL TIME STEP 6 (SECONDSI LAST TIME TO USF CALCILATIONAL TIME STEP 6 (SECONOS FROM TIMEO) CAI CILLATIONAL TIME STEP $T$ (SECONDS) I AST TIME TO USE CALCILLTIONAL TIME STEP 7 (SECONOS FROM TIMEO) CALCIILATIONAL TIME STEP R (SECONDS) LAST TIME TO USF CALCILLATIONAL TIME STEP 8 ISECONOS FROM TIMEOI CalCULATIONAL TIME STEP 9 (SECONDS) IAST TIME TO USE CALCULATIONAL TIME STEP 9 (SECONDS FROM TIMEO) CAI CILATIONAL TIME STEP 10 (SECONDS) LAST TIME TO IISE CALCILATIONAL IIMF STEP 10 (SECONUS FROM TIMEO) CALCILATIONAL TIME STEP II (SECONIIS)

LAST TIME TO IISE CALCULATIONAL TIME STEP 11 (SECONDS FROM TIMEO) 


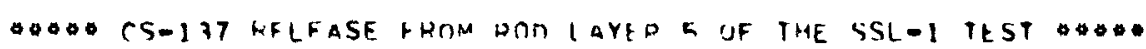

\begin{tabular}{|c|c|c|c|c|}
\hline CARO & $\begin{array}{c}\text { CARD } \\
\text { FORMAT }\end{array}$ & COLIIMPIS & SYAFFOL & $\begin{array}{l}\text { VALIIE } \\
\text { USEN }\end{array}$ \\
\hline 70 & & $\begin{array}{l}49-50 \\
61=72\end{array}$ & $\begin{array}{l}\text { MF(TAT }(2) \\
\text { TMAX( } 1 ?)\end{array}$ & $\begin{array}{l}1.00 n 00 n+01 \\
1.344400+105\end{array}$ \\
\hline $7 E$ & & $\begin{array}{l}1=12 \\
13-24 \\
25-36 \\
37-48 \\
49-60 \\
61-72\end{array}$ & $\begin{array}{l}\text { DELTAT ( 13) } \\
\text { TMAX( 13) } \\
\text { DFLTAT ( 14) } \\
\text { TMAX( 14) } \\
\text { OFLTAT( } 151 \\
\text { TMAX( 15) }\end{array}$ & $\begin{array}{l}6.000000+01 \\
7.380000+05 \\
3.600000+03 \\
7.776000+05 \\
4.320000+04 \\
1.771200+06\end{array}$ \\
\hline $7 F$ & & $\begin{array}{l}1-12 \\
13-24 \\
25-36 \\
37-48 \\
49-60 \\
61-72\end{array}$ & 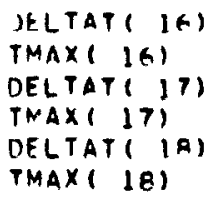 & $\begin{array}{l}1.000000+00 \\
1.771210+06 \\
1.000000001 \\
1.771250+06 \\
6.000000+01 \\
1.774800+06\end{array}$ \\
\hline 76 & & $\begin{array}{l}1-12 \\
13-24 \\
25-36 \\
37-48 \\
49-40 \\
61-7 ?\end{array}$ & $\begin{array}{l}\text { DELTAT } 191 \\
\text { TMAX( 19) } \\
\text { DELTAT } 201 \\
\text { TMAXY } 201 \\
\text { DELTAT } \\
\text { TMAX( } 211)\end{array}$ & $\begin{array}{l}3.600000+03 \\
1.816400+06 \\
4.320000+04 \\
1.944000+06 \\
1.000000+00 \\
1.744010+06\end{array}$ \\
\hline $7 H$ & & $\begin{array}{l}1-12 \\
13-24 \\
25-36 \\
37-48 \\
49-40 \\
61-72\end{array}$ & $\begin{array}{l}\text { RELTAT ( 22) } \\
\text { TMAX( } 2 ?) \\
\text { 'ELLAT } \\
\text { TMAX( } 231 \\
\text { DELTAT }(24) \\
\text { TMAX( } 24)\end{array}$ & $\begin{array}{l}1.000000+01 \\
1.944060 * 06 \\
6.000000+01 \\
1.947600 * 06 \\
3.600000 * 03 \\
1.987200 \cdot 06\end{array}$ \\
\hline 71 & & $\begin{array}{l}1-1 ? \\
13-24 \\
25-36 \\
37-48 \\
49-40 \\
61-72\end{array}$ & $\begin{array}{l}\text { DELTATS } 25) \\
\text { TMAX( } 25) \\
\text { UELTAY }(26) \\
\text { TMAX( } 2(6) \\
\text { OELTAT( } 27) \\
\text { TMAX( } 27)\end{array}$ & $\begin{array}{l}4.320000+04 \\
2.592000+06 \\
1.000000+01 \\
2.592010+06 \\
1.000000+11 \\
2.592060+06\end{array}$ \\
\hline 74 & & $\begin{array}{l}1-12 \\
13-24 \\
25=36 \\
37=49 \\
49-4 n \\
41-7 ?\end{array}$ & 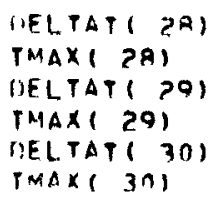 & $\begin{array}{l}3.000000+01 \\
2.595600+06 \\
3.600000+03 \\
2.635200+06 \\
4.320000+04 \\
3.7400100+06\end{array}$ \\
\hline $7 k$ & & $\begin{array}{r}1-17 \\
13-24\end{array}$ & $\begin{array}{l}\text { DELTATI 31) } \\
\text { TMAX( 31) }\end{array}$ & $\begin{array}{l}1.000000+00 \\
3 .>40510+06\end{array}$ \\
\hline
\end{tabular}

DESCHIPTJON

CALCILATIONAI TIME STEP IP (SECONDS) LAST TIME TO USE CALCULATIONAL TIME STEP 12 ISECONOS F CALCILATIONAL ITINF STEP 13 (DECUNOS) LAST IIME TO USE CALCILATIOINAL IIME STEP 13 ISECONOS F CALCIULATIONAL TIME STED I" (SECONDS) LAST TIME TO USE CALCULATIOHAL IIME STEP IA ISECONDS F CALCIILATIONAL TIME STEP 15 (SECONDS) I.AST TIME. TO USE CALCIJLATIONAL TIME STEP 15 ISECONDS FI

CAICILLTIONAL TIME STEP 16 (SECONDS)

LAST TIME TO IISE CALCULATIONAL TIME STEP 16 ISECONDS F? CALCIHATIONAL TIMF STEP 17 (SECONDS) LAST TIME TO USE CALCULATIONAL TIME STEP 17 ISECONDS FF CALCILATIONAL TIME STEP 18 (SECONOS) LAST TIME TO USE CALCULATIONAL TIME STEP 18 ISECONOS FR

CALCILLTIONAL TIME STEP 19 (SECONDS) LAST TIME TO USE CALCULATIONAL TIME STEP 19 ISECONOS FR CALCULATIONAL TIME STEP 20 (SECONDS) LAST TIME TO USE CALCULATIONAL TIME STEP 20 ISECONUS FR. CALCULATIONAL TIME STEP II ISECONDSI CALCULATIONAL TIME STEP 21 (SECONDS)
LIST TIME TO USE CALCULATIONAL TIME STEP 21 ISECONOS FRI CALCILATIONAL TIME STEP 22 (SECONDS) LAST TIME TO ISE CALCULATIONAL TIME STEP 22 ISECONOS FRS CAL.CULATIONAL TIME STEP 23 (SECONOS) LAST TIME TO USE CALCULATIONAL TIME STEP 23 (SECONDS FRC CALCIULATIONAL TIME STEP 20 (SECONOS) LAST TIME TO USE CALCULATIOINAL TIME STEP 24 ISECONDS FRO

CALCILATIONAL TIME STEP 25 (SECONDS)

LAST TIMF IO USF CALCULATIONAL TIME STEP 25 ISECONDS FRO CALCILATIOAAL TIME STEP 26 (SECONOS) LAST TIME TO USE CALCIILATIONAL TIME STEP 26 (SECONOS FROI CALCILATIONAL TIME STEP 27 (SECONOS) LAST TIME TO LISE CALCULATIONAL TIME STEP $2 T$ ISECONDS FROI

CALCINLTIUNAL TIME STEP CR (SECONOSS)

LAST TIME TO USE CALCULATIONAL TIME STEP 28 ISECONDS FRON CALCILATIONAL TIME STEP 29 (SECONDS) LAST TIME TO USE CALCULATIONAL TIME STEP 29 ISECONDS FROM CALCINLIIOTAL TIME STEP 30 (SECONOS) IAST TIME TO IISE CAICILATIOVAL PIME STFP 30 ISECONOS FROM

CALCIILATIONAL TIME STEP 3 (SECONDS)

LAST TIME TU USF CALCILATIOMAL TIME STEP 31 ISECONOS FROM 


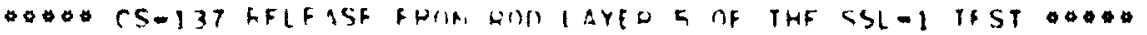

$7 x$

$7 \mathrm{M}$
25-36

$37-4 h$

$49-60$

$61-72$

$61-72$

TP
$1-13$

$13-24$

$25-34$

$25-3 h$
$37-48$

$49-60$

$61-72$

$1-12$
$13-24$

$25-36$

$25-36$

$49-4$

$1-1$ ?

$13-24$

$25-36$

$37-48$

$49-60$

$61-7$ ?

$1-12$

$13-24$

$25=36$

$37-48$

$49-60$

$1-12$

$13-34$
$13-15$

$25-36$

$25-36$
$37-48$

$49-60$

$41-72$

SYNHOL

DER(TAT, JP) TMAX (3)) UELITAT (3) TMAX ( 3)

IIFLTATI 74) TMAX (34) ITELTAT (35) imaxt 35i TMA DFLTATI BSI TMAX( 3h)

DELTAT ( 37$)$ TMAX (37) DFLTAT (3B) TMAX( 3A) DELTATI 391 TMAX (39)

DELTAT G OI TMAX ( 40) DELTAT ( I) THAX ( 411 DELTAT ( 42) TMAX ( 42)

OELTAT ( 431 TMAX (43) DELTAT ( AB) TMAX ( 44) DELTAT ( 45) TMAX( 45)

IIFI TAT( 4A) TMAX ( 4B) DELTAT (4) TAAX (47) I)FL TAT ( 4R) IMAX ( 4R)

$1-17$ $13-7$

$25-36$

$25-36$

37-4 TMAX(49) DFLTAT (50) IMAX( GO)
VALUIF
USEN

$1.004000011)$ $3.2410 n s 0006$ $6.0 n 0000001$ $3.2434 n n+06$

$3.600000+03$ $3.283200+06$ $4.320000+04$ 3.450000006 1. $0000 n n+01$ 3.456n10+06

$1.000000+01$ 3.456060 .06 6.000000 .01 $3.459600+06$ 3.459600 .06 3.499200 .06

$4.320000+04$ $4.190400+06$ $1.000090+00$ $4.191) 410+n$ A $1.0000010+01$ $4.190460+n$

4.000000.01 4.194000400 $3.600000+03$ $4.233600+06$ 4.320000 .04 4.968000006

$1.000010+00$ $4.368010+06$ 1.00000 $4.948060+0$ a $6.0000 n 0+01$ $4.971600+04$

IIFLTAT( 49$) \quad 3.4000 n n+n 3$ DELTATL 511 TMAX( 51 ) 5.0112n0+05

$5.124000+06$

$1.000000+10$

$5.184010+06$
DESCDIDTION

CAI C 11 GIITINAL TIME STEF 3? (SECONOSI LAST TIMF TO IISE CALCHLATIONAL IIME STEP 32 (SECONUS FROM TIMEO) CaLCIHLTIOHAL TIME STEP 33 (SECONDS)

LAST TIME TO USE CALCILLATIONAL TIME STEP 33 (SECONDS FROM TIMEO)

CALCIILATIONAL TIME STEP 34 (SECONOS)

LAST TIME TO USE CALCULATIOVAL TIME STEP 34 (SECONDS FROM TIMEOI CALCILLTIONAL TIME STEP 35 (SECONDS)

LAST TIME TO IISF CALCULATIOHAL TIME SIEP 35 ISECONDS FROM TIMEOI CaLCILATIONAL TINE SIFP 36 (SECONOSI LAST TIIAF TO USE CALCILATIONAL TIME STEP 36 (SECONDS FROM TIMEO)

CALCILATIONAL TIME STEP 37 (SECONDS)

LAST TIME TO USE CALCULATIOVAL TIME STEP 37 (SECONDS FROM TIMEO) CALCIILATIONAL TIME STEP $3 B$ ISECONDSI

LAST TIME TO USE CALCULATIONAL TIME STEP CALT TIME TOL TSE CALCIULTIONAL TIME STEP LAST TIME TO USE CALCULATIONAL TIME STEP

38 (SECONOS FROM TIMEO) 39 (SECONOS FROM TIMEO)

CALCULATIONAL TIME STEP 40 ISECONDSI

LAST TIME TO LISE CALCULATIONAL TIME STEP 40 (SECONDS FROM TIMEO) CALCIILATIONAL TIME STEP II (SECONDS)

LAST TIME TO IISE CALCILATIONAL TIME STEP I I (SECONDS FROM TIMEO) CALCIJLATIONAL TIME STEP 42 (SECONDS)

I.AST TIME TO USE CALCULATIONAL TIME STEP

-2 (SECONDS FROM TIMEO)

CALCIILATIOAAL TIME. STEP 3 ISECONDS)

LAST TIME TO USE CALCULATIOVAL TIME STEP CALCILLATIONAL TIME STEP 4 (SECONDS)

LAST TIME TO USE CALCILATIONAL TIME STFP CALCIUATIONAL TIME STEP 5 (SECONOS)

LAST TIHE TO USE CaLCILLATIONAL TIME STEP

3 (SECONDS FROM TIMEOI

4 (SECONOS FROM TIMEO)

45 (SECONDS FROM TIMEO)

CHCILATIOHAL TIMF STEP AR (SECONOS)

LAST TIME TO USE CALCULATIOVAL TIME STEP CALCILATIONAL TIME STEP I TSECONDS)

LAST TIME TO IISF CALCULATIONAL IIME STEP CALCHIITTIONAL TIME STEP AA (SECONDS)

LAST TIME IO IISE CALCLLATIONAL TIME STEP

46 (SECONDS FROM IIMEO)

47 (SECONDS FROM TIMEO) 4A (SECONOS FROM TIMEO)

CALCULATIONGL TINE STEP 49 (SECONDS)

LAST TIMF TO USE CALCULATIONAL TIME STEP 99 (SECONOS FROM TIMEO) CALCIII.ATIOIVAL TIME STFP 50 (SECONOS)

I. AST TIME TO IISE CALCULATIONAL TIME STEP 50 (SECUNOS FROM TIMEO) CaLCULATIONAL TIME STEP 51 (SECONOS)

LAST TIME TO USF CALCULATIONAL TIME STEP 51 (SECONOS FROM TIMEO) 


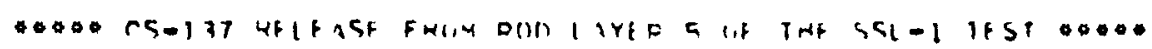

\begin{tabular}{|c|c|c|c|c|}
\hline CARD & $\begin{array}{l}\text { CARD } \\
\text { FORMAT }\end{array}$ & COL tiatNS & SYMHOL & $\begin{array}{l}\text { VALIIF } \\
\text { IISER }\end{array}$ \\
\hline 70 & & $\begin{array}{l}1-17 \\
13-24 \\
25-36 \\
37-4 A \\
49-40 \\
61-72\end{array}$ & 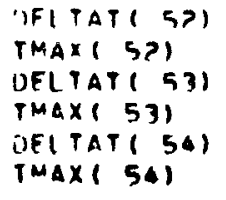 & $\begin{array}{l}1.0,110 n 00+01 \\
5.194060+06 \\
6.000000+01 \\
5.197600+06 \\
3.600000+03 \\
5.227200+06\end{array}$ \\
\hline 75 & & $\begin{array}{l}1-17 \\
13-24 \\
25-24 \\
37-48 \\
49-60 \\
61-72\end{array}$ & $\begin{array}{l}\text { DELTAT (55) } \\
\text { TMAX( 551 } \\
\text { IELTAT } 56) \\
\text { TMAX( 56) } \\
\text { DELTAT } 57) \\
\text { TMAX } 571\end{array}$ & $\begin{array}{l}1.320000+04 \\
5.961600+168 \\
1.0 n 00 n 0+011 \\
5.961610+06 \\
1.000000+01 \\
5.961660+166\end{array}$ \\
\hline $7 T$ & & $\begin{array}{l}1-12 \\
13-24 \\
25-34 \\
37-48 \\
49-60 \\
61-72\end{array}$ & $\begin{array}{l}\text { DELTAT (5A) } \\
\text { TMAXP 5B) } \\
\text { DELTAT1 59) } \\
\text { TMAXY 59) } \\
\text { DELTAT ( 60) } \\
\text { TMAX( 60) }\end{array}$ & $\begin{array}{l}6.000000+01 \\
5.965200 \times 06 \\
3.600000+03 \\
6.004800006 \\
4.320000004 \\
6.739200 .06\end{array}$ \\
\hline 70 & & $\begin{array}{l}1-12 \\
13-24 \\
25-36 \\
37-48 \\
49-40 \\
61-72\end{array}$ & $\begin{array}{l}\text { DELTATI } 611 \\
\text { TMAX( } 611 \\
\text { UELTATI G2) } \\
\text { TMAX( 62) } \\
\text { UFLTATI A3) } \\
\text { TMAX( G3) }\end{array}$ & $\begin{array}{l}1.000000+00 \\
0.739210+06 \\
1.000010001 \\
6.739260 .06 \\
6.000000001 \\
0.742900+06\end{array}$ \\
\hline $7 v$ & & $\begin{array}{l}1-12 \\
13-24 \\
25-36 \\
37-48 \\
49-6 n \\
61-72\end{array}$ & 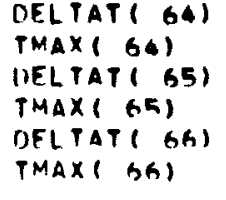 & $\begin{array}{l}3.600000+03 \\
6.782400+06 \\
4.320000+06 \\
6.868 R 00+06 \\
1.000000+00 \\
6.368 R 10+06\end{array}$ \\
\hline $7 w$ & & $\begin{array}{l}1-12 \\
13-24 \\
25-36 \\
37-48 \\
49-60 \\
61-72\end{array}$ & $\begin{array}{l}\text { DELTAY } 671 \\
\text { TMAXI } 671 \\
\text { DELTAT } \\
\text { TMAXY } 691 \\
\text { DELTATI } 691 \\
\text { TMAX( } 691\end{array}$ & $\begin{array}{l}1.000000+11 \\
6.868860+06 \\
6.000000 .01 \\
6.872400+06 \\
3.600000+03 \\
6.912000+16\end{array}$ \\
\hline $7 x$ & & $\begin{array}{l}1-12 \\
13-24 \\
25-36 \\
37-48 \\
49-4 C \\
41-72\end{array}$ & 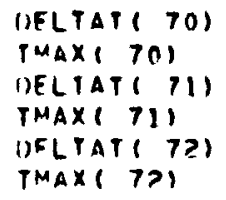 & $\begin{array}{l}4.320000+04 \\
7.689600+06 \\
1.000000+00 \\
7.659610+06 \\
1.000000+01 \\
7.649600+06\end{array}$ \\
\hline
\end{tabular}

UESCDIPIIIOR:

CAICILAITIONAL TIME STEP b? (SECONDS)

LAST TIME 10 USE CALCULATIONAL TIME STEP 52 (SECONOS FROM TIMEO) CALCIILATIONRL TIME STEP 53 (SECONDSI

I ASI TIME IO USE CALCILLAIONAL TIME STEP 53 (SECONOS FROM TIMEOS CALCULATIONAL TIME STEP 5\% (SECONOS)

LAST TIME to uSE CALCULATIONAL TIME STEP 54 (SECONOS FROM TIMEOO)

CAI CILLAIIMIAL TIME STEP 55 (SECONDS)

LAS' TIMF IO LISE CALCULATIONAL TIME STEP 55 (SECONOS FROM TIMEO) CAICILATICIALL TIME STEP SO ISECONDSI

LAST TIWE TO LISE CALCULATIONAL TIME STEP 56 (SECONOS FROM TIMEO) CALCILATIONAL TIME STEP 59 (SECONDS)

LAST TIME TO USE CALCULATIONAL TIME STEP 57 (SECONOS FROM TIMEO)

CALCILATIONAL TIME STEP 58 (SECONOS)

LAST TIME TO USE CALCULATIONAL TIME STEP 58 (SÉCONÓS FROḾ TIMEOT) CALCILATIONAL TIME STEP 59 (SECONOS)

LAST TIME IO USE CALCULATIONAL TIME STEP CALCILATIONAL TIME SIEP 60 (SECONOS) LAST PIME TO USE CALCULATIONAL TIME STEP 60 (SECONDS FROM TIMEOT-

CALCILLATIONAL TIME STEP OI (SECONOS)

LAST TIME TO IISE CALCILATIONAL TIME STEP GI ISECONUS FROM TIMEOI CALCILATIONAL TIME STEP 62 (SECONDS)

LAST TIME TO USF CALCULATIONAL TIME STEP 62 (SECONDS FROM TIMEO) CALCILATIONAL TIME STEP G3 (SECCIMUS)

LAST TIME TO USE CALCILATIONAL TIME STEP 63 (SECONDS FROM TIMEO)

CALCIJLATIONAL TIME STEP GA (SECONOS)

LAST TIME TO USE CALCULATIONAL TIME STEP 64 (SECONDS FROM TIMEOO) CALCIILATIONAL TIME STEP 65 (SECONOS)

LAST IIIIE TO USE CALCULATIONAL TIME STEP 65 (SECONOS FROM TIMEO)

CAL CIILATIONAL TIME STEP GG (SECONDSI

LAST TIME TO IISE CALCULATIONAL TIME STEP 66 (SECONOS FROM TIMEO)

CALCILATIIJNAL TIME STEP GT (SECONOS)

LAST TIME TO USE CALCULATIONAL TIME STEP $6 T$ (SECONOS FROM TIMEO)

LAST TIME TO USE CALCULATIONAL TIME STE

CALCILLATIOMAL TIME STEP 6A (SECONOS)

LAST TIMF TO USF CALCULATIONAL TIME STEP GE (SECONDS FROM TIMEO) CALCILLTIOPIAL TIME STEP 69 (SECONDS)

LAST TIMF TO USE CALCILATIONAL TIME STEP 69 (SECONOS FROM TIMEO)

CaLCILLTIONAL TIME STEP 10 (SECONOS)

LAST TIMA 10 IISE CALCIILATIONAL TIME STEP 70 (SECONOS FROM TIMEO) CALCILLTIONAL TIMF STEF 11 (SECONDS)

LAST TIME TO USE CALCULATIUNAL IIMF STEP 11 (SECONDS FROM TIMEO) CALCULATIONAL TIME STEP 72 (SECONOS)

LAST TIME TU USF CALCILATIONAL TIME STEP 72 (SECONOS FROM TIMEO) 
\$000 CS-137 RELEASE FROM PUI I AYF" h OF THE. SSL-I IEST OAOA

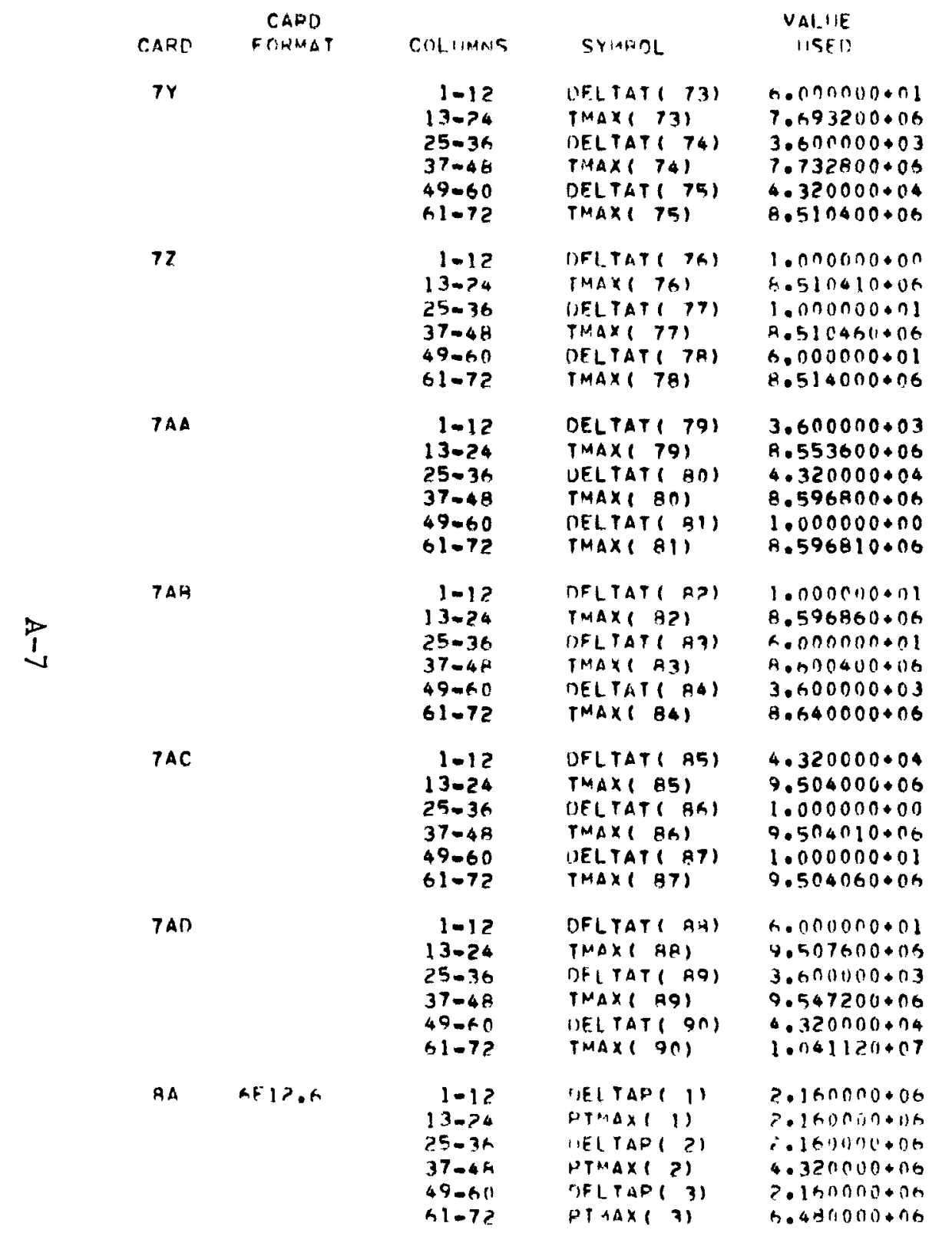

DH SCHIRTION

CALCIJLATIONAL TIME STEP 13 (SELONUS)

I AST TIME TO USF CALCILATIOVAL TIME SIFP 73 (SECONDS FROM TIMEO) CALCILLTIONAL TIME STEP TA (SECONOS)

LAST IIME TO USE CALCULATIONAL TIME STEP 7 ISECONOS FROM TIMEOI CALCILLATIONAL TIME STEP TS ISECONDSI

LAST TIME TO USE CALCILATIONAL TIME STEP 75 (SECONOS FROM TIMEOI

CALCILATIOHIAL TIMF STFD TA (SECONDS)

LAST ITME TC HSF CALCILATISNAL IIME STEP 76 (SECONDS FROM TIMEO) CALCILATIONAL TIME STEP 77 (SECONDSI

LAST TIME TO USE CALCILATIOUAL TIME STEP 77 ISECONOS FROM TIMEOI CALCHLATIDNAL TIME STEP 78 (SECONDSI

LAST TIME TO USE CALCULATIONAL TIME STEP 78 (SECONDS FHOM TIMEOI

CALCULATIONAL TIME STEP 19 (SECONOSI

LAST TIME TO USE CALCULATIONAL TIME STEP 79 (SECONOS FROM TIMEO) CALCILATIONAL TIME STEP 80 (SECONDSI

LAST TIME TO USE CALCULATIONAL TIME STEP 80 (SECONDS FROM TIMEO) CALCULATIONAL TIME STEP OI (SECONOS)

LAST TIME TO USE CALCULATIONAL TIME STEP 1 (SECONOS FROM TIMEÓ)

CAICILATIOR.AL TIME STEP g? (SECONDS)

LAST TIME TO USE CALCULATIONAL TIME STEP 82 (SECONOS FROM TIMEO) CALCILLTINNAL TIME STEP 83 (SECONDS)

IAST TIME TO USF CALCINATIOINAL IIME STEP 83 (SECONDS FROM TIMEO) CALCULATIONAL TIME STEP OH (SECONDS) LAST TIME TO USE CALCULATIONAL TIME STEP 84 (SECONDS FROM TIMEOS

CALCILLATIONAL TIME STEP H5 (SECONDSI

LAST TIME TO USE CALCULATIONAL TIME STEP 85 (SECONOS FROM TIMEO)

CALCULATIONAL TIME STED 86 (SECOHDSI
LAST TIMF TO IISE CALCILLATIOINAL TIME STEP 86 (SECONDS FROM TIMEO) CALCILLATIONAL TIME STEP 87 (SECONDS)

LAST TIME TO IJSE CALCULATIONAL TIME STEP aT (SECONDS FROM TIMEO)

CALCIILATIONAL TIME STEP B8 (SECONDS)

LAST IIME TO USE CALCILATIONAL TIME STEP AO (SECONOS FROM TIMEOS CALCIILATIONAL TIME STHP BO ISECONDSI

LAST TIME TO USE CALCULATIONAL TIME STEP 89 (SECONOS FROM TIMEO) CALCULATIONAL TIME STEP 90 (SECONDS)

LAST TIME TO LISE CALCULATIONAL TIME STEP 90 (SECONDS FROM TIMEO)

GMINT TIME STEP I ISFCONOS)

ENI OF PRINT TIMF STEP 2 (SECONDS FRUM TIMEO) PHINT TIME STFP ? (SFCONUS)

FUR OF PRINT TIMF STFP 2 (SECONDS FRUM TIMEO)

PHINT IIME SIEP 3 (SECONUS)

ETII) OF PAINT TIM.F STEP 3 (SECOVUS FROM TIMEO) 


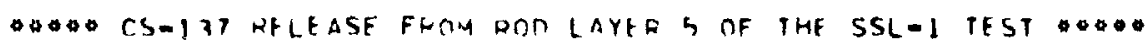

\begin{tabular}{|c|c|c|c|c|}
\hline CARO & $\begin{array}{l}\text { CADA } \\
\text { FOPAAT }\end{array}$ & Coli/MNS & SYMHO) & $\begin{array}{l}\text { VALUIE } \\
\text { IISEN }\end{array}$ \\
\hline $8 \mathrm{H}$ & & $\begin{array}{l}1-12 \\
13-24 \\
25-36 \\
37-48\end{array}$ & $\begin{array}{l}\text { DELTAP ( } 4) \\
\text { DTMAX( 4) } \\
\text { DELTAP ( 5) } \\
\text { PTMAX ( 5) }\end{array}$ & $\begin{array}{l}2.203200 \rightarrow n \text { A } \\
2.693200+06 \\
1.727900 .06 \\
1.041100+07\end{array}$ \\
\hline 9A & KE 12.0 & $\begin{array}{r}1-12 \\
13-24 \\
25-36 \\
37-4 R\end{array}$ & $\begin{array}{l}\text { STEP(1) } \\
\text { STPN(IM } 11) \\
\text { STFP (D) } \\
\text { STPNIIM }(2)\end{array}$ & $\begin{array}{l}2.270000=02 \\
1.900000+01 \\
1.360000-02 \\
3.300000001\end{array}$ \\
\hline $10 \mathrm{a}$ & $3(I 12 . E 12.6)$ & $\begin{array}{r}1-12 \\
13-24\end{array}$ & $\begin{array}{l}\operatorname{Irac}(1) \\
x \in C(1,1)\end{array}$ & $\begin{array}{c}52 \\
0.000000\end{array}$ \\
\hline $12 \mathrm{~A}$ & $2(112,2 E 1>0.6)$ & $\begin{array}{r}1-12 \\
13-24\end{array}$ & $\begin{array}{l}\text { NMDOS }(1) \\
\text { DAASE }(1,1)\end{array}$ & $\frac{18}{2.500000-06}$ \\
\hline & & $25-36$ & EBASE $(1,1)$ & $3.900000+04$ \\
\hline & & $\begin{array}{l}37=48 \\
49-40\end{array}$ & $\begin{array}{l}\text { NMDQ (?) } \\
\text { ORASE }(2,1)\end{array}$ & $\begin{array}{c}52 \\
1.220 \cap 00-119\end{array}$ \\
\hline & & $61-72$ & EAASE $(2,1)$ & $3.440000+04$ \\
\hline $13 A$ & $6 F 12.5$ & $\begin{array}{l}1-12 \\
13-24 \\
25-36 \\
37-48 \\
49-6 n \\
61-72\end{array}$ & 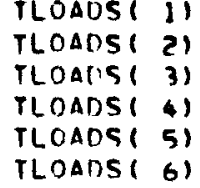 & $\begin{array}{l}2.160000+05 \\
7.344000+05 \\
1.771200+06 \\
1.944000+06 \\
2.592000+06 \\
3.240000+06\end{array}$ \\
\hline 136 & & $\begin{array}{l}1-12 \\
13-24 \\
25-36 \\
37-44 \\
49-60 \\
61-12\end{array}$ & 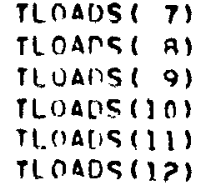 & $\begin{array}{l}3.456000+106 \\
4.190400+06 \\
4.968000+04 \\
5.144000+06 \\
5.761600+06 \\
6.739200+06\end{array}$ \\
\hline $13 c$ & & $\begin{array}{l}1=12 \\
13-24 \\
25-36\end{array}$ & $\begin{array}{l}\text { TLADS (13) } \\
\text { rLCAOS(1) } \\
\text { TH UANG(15) }\end{array}$ & $\begin{array}{l}6.868 A 00+06 \\
7.689600 \div 06 \\
R .510400+16\end{array}$ \\
\hline
\end{tabular}

IIE SCDIPTION

PHIIIT TIYE SIEP " (SFCONUS)

ER.D OF PEIMT TINE STFP A (SECONDS FROM TIMEOI

PRINT TIME STEP 5 (SECONDS)

ENO OF PRINT TIME STEP 5 (SECONOS FROM TIMEO)

MESH SILE \& STARTING FROM IINNER BOUNDARY (CM)

NUMAER OF TIMES MESH SIZE I IS TO BE USED

MFSH SIZE 2 STARTING FROM INNER BOUNDARY (CM)

NIINPFR UF TIMES MESH SITF ? IS 10 BE USED

LAST MFSH POINT TO USE THE FOLLUWING INITIAL CONCENTRATION

VALIIE OF INITIAL CONCENTRATION OF ISOTOPE I FROM MESH POINT I TO 52 (MICROMOLES/CC)

LAST MESH PUINT TO USE THE FOLLOWING DIFF COEF AND ACTIVATION ENERGY VALUF OF UIFF COEF (AT TRASE) FUR ISOTOPE. I FROM MESH POINT I TO 18 (SOCM/SEC)

ACTIVATIOP: ENERGY FOR ISOTOPE I FROM MESH POINT 1 TO 18 (CAL/MOLE)

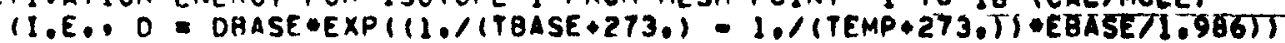
LAST MESH POINT TO USE THE FOLLOWING DIFF COEF AND ACTIVATION ENEREY VALIIE OF DIFF COEF IAT TRASE) FJR ISOTOPE I FROM MESH POINT 19 TO 52 (SOCM/SEC)

ACTIVATIONI ENERGY FOR ISOTOPE I FROM MESH POINT 19 TO 52 (CAL/MOLE)

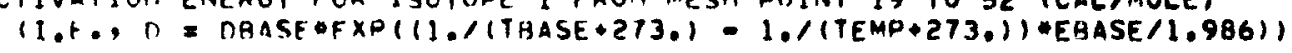

END OF INPUT TIME INTERVAL I (SECONOS)

ENO OF INPUT TIME INTEAVAL 2 (SECONOS)

FND OF INPUT TIME INTERVAL 3 (SECONDS)

ENO OF INPUT TIME INTERVAL (SECONOS)

END OF INPUT TIME INTERVAL 5 (SECONDS)

ENI) OF INPUT TIME INTERVAL 6 (SECONDS)

EMT OF INPUT TIME INTERVAL 7 (SECONOS)

EIIT OF INPUT TIME INTERVAL Q (SECONDS)

EII) OF INPIIT TIMF INTERVAL O (SECONOS)

END OF INPUI TIMF INTERVAL 10 (SECONOS)

EHID OF INPIT TIME INTERVAL 11 (SECONOS)

END OF INPUY TIME INTERVAL 12 (SECONDS)

FHD OF INPUY TIME INTERVAL 13 (SECONDS) END OF INPUT TIME INTERVAL I4 (SECONDS)

EHD OF INDIIT TIMF INTELVAL IS (SECONOS) 
00000 CS-131 RRLEASE FROM ROD LAYE 5 OF THE SSL-1 TEST 00000

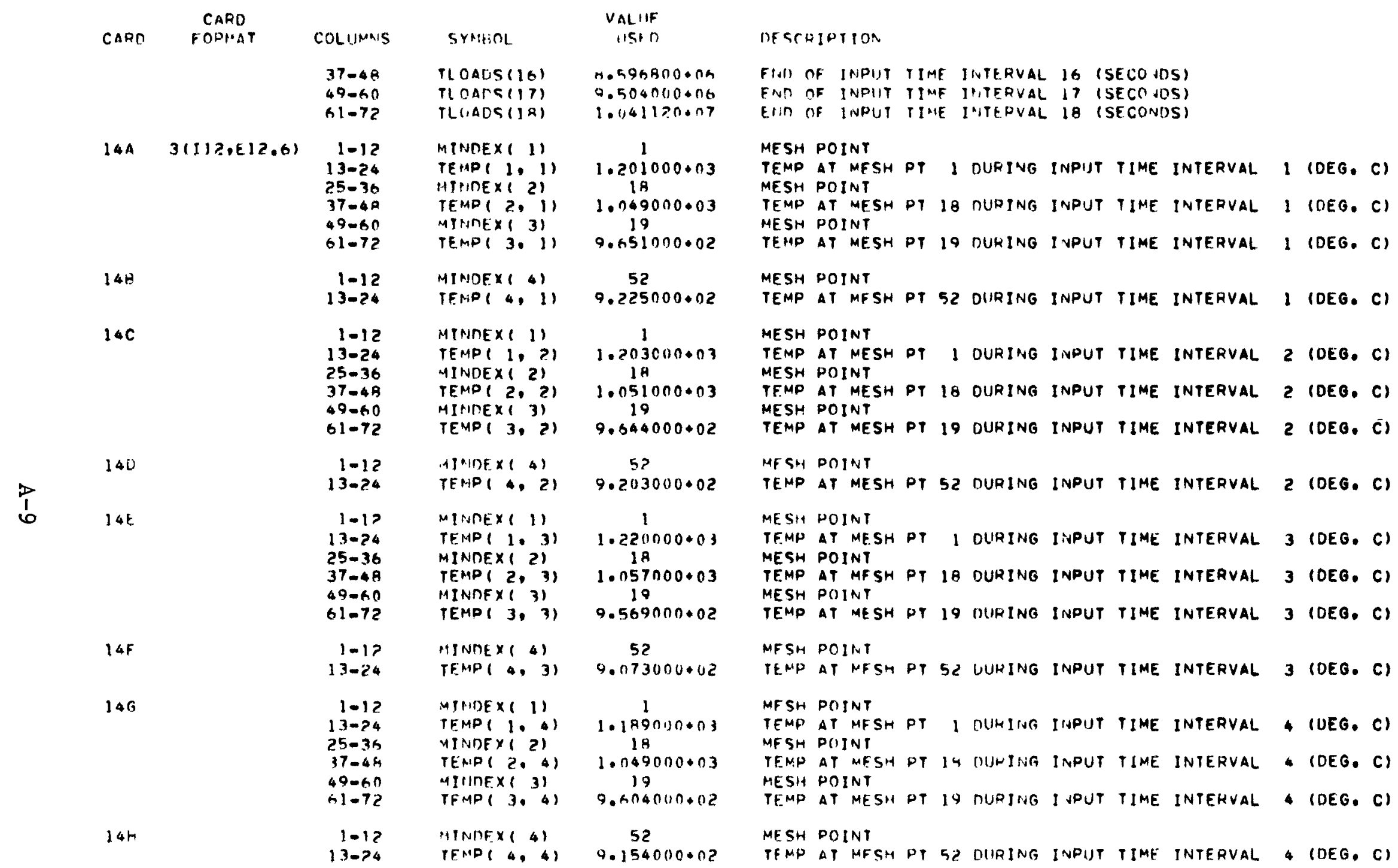




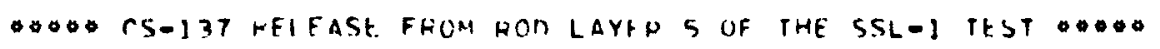

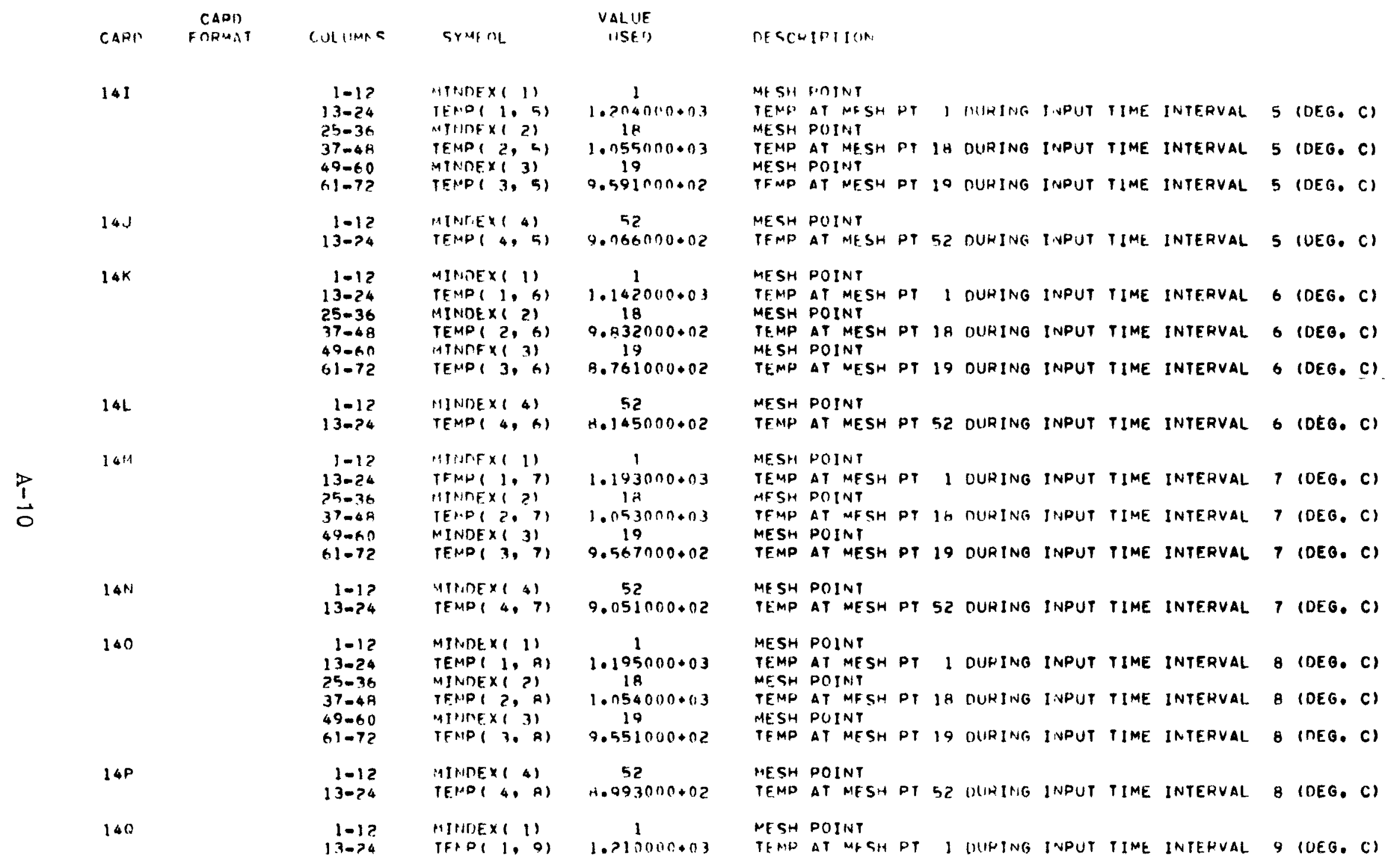




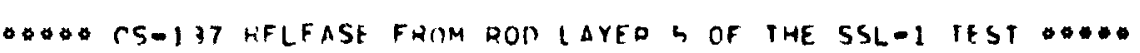

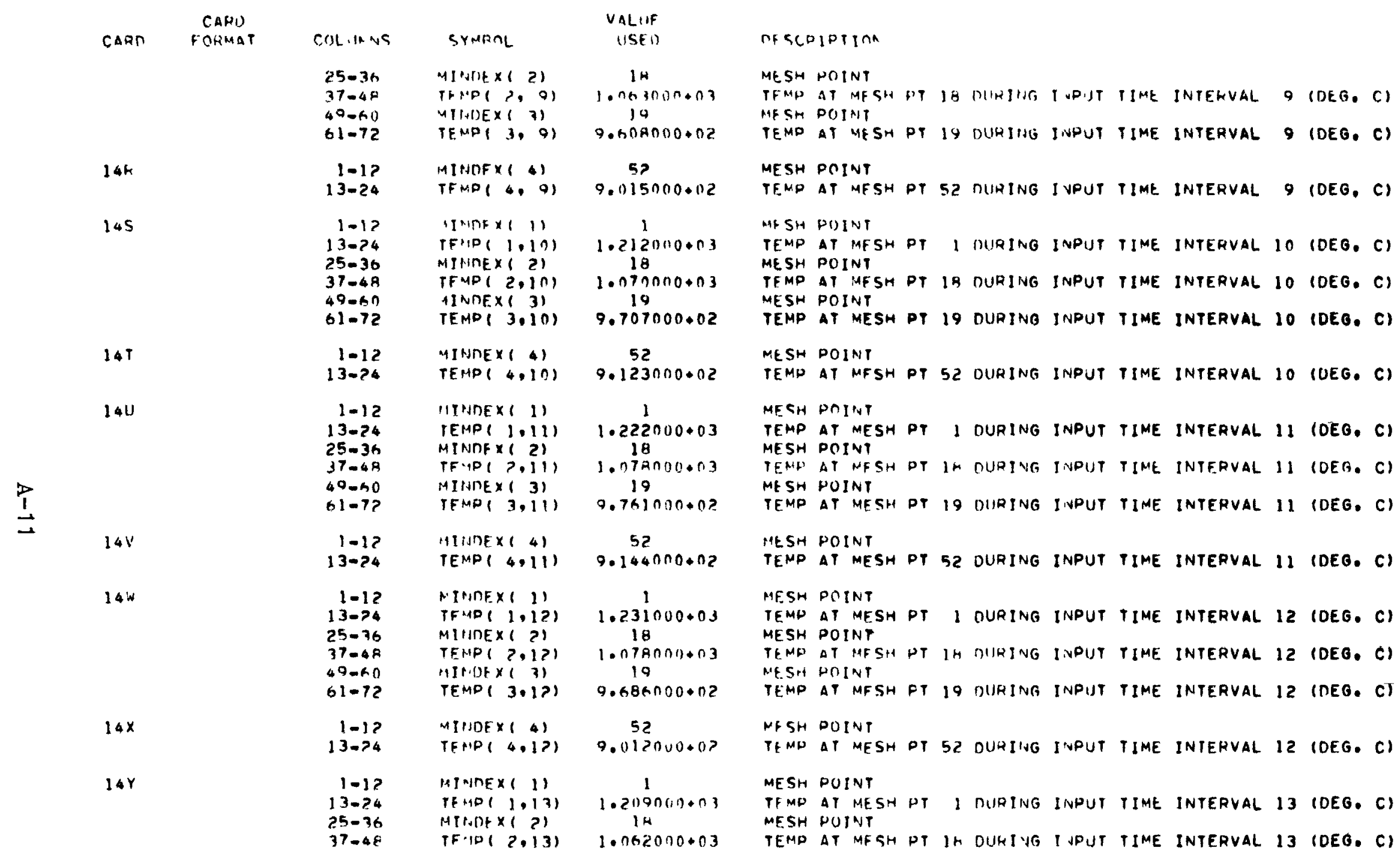




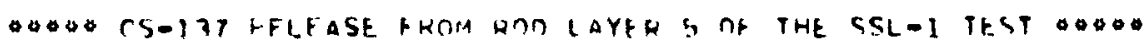

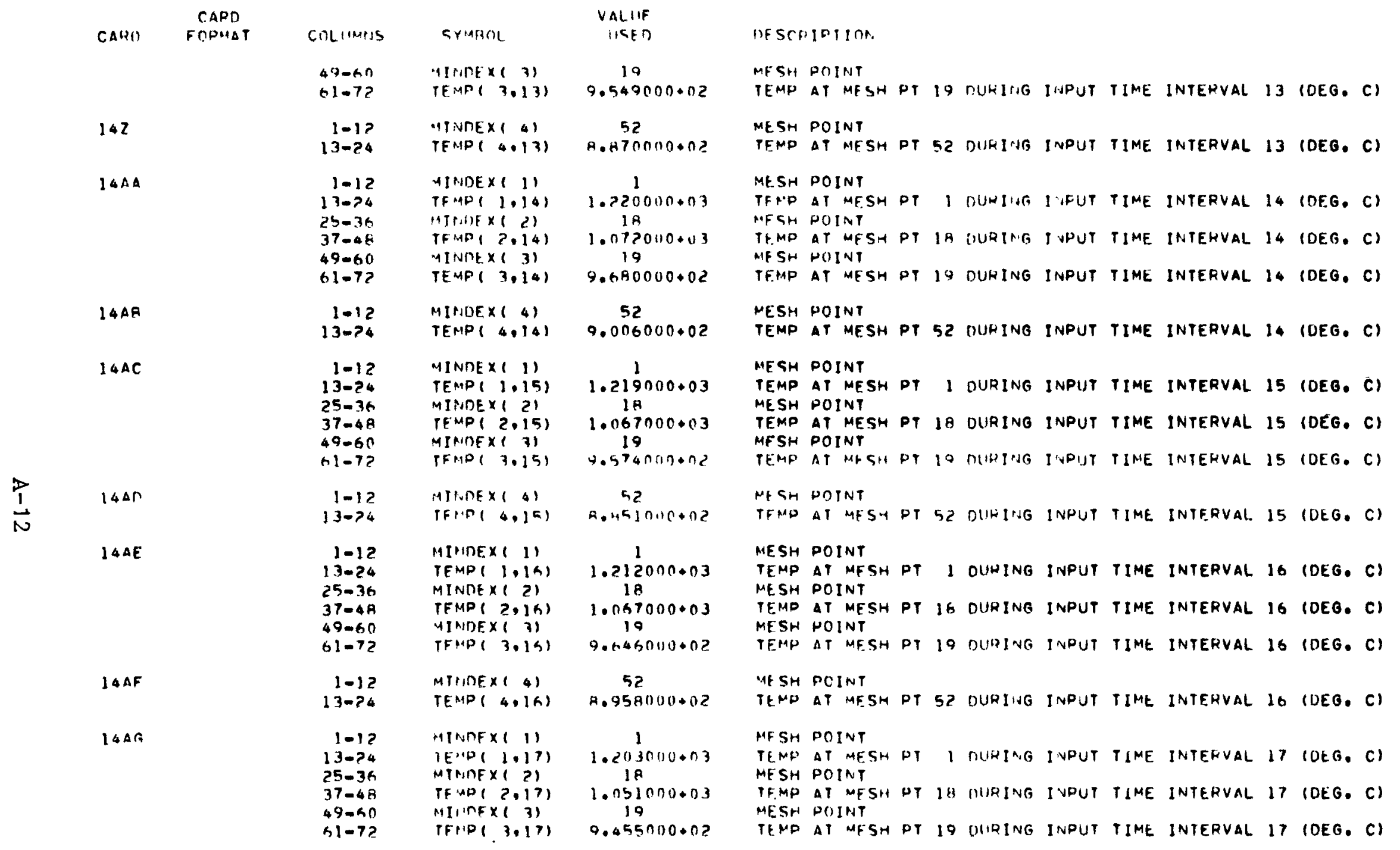




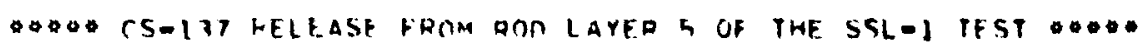

\begin{tabular}{|c|c|c|c|c|c|c|c|c|c|c|c|c|c|}
\hline $\begin{array}{c}\text { CAPD } \\
\text { CAFH FORHAI }\end{array}$ & COLINits & SYAwnl & $\begin{array}{l}\text { VALLIF } \\
\text { IISFU }\end{array}$ & lit $\mathrm{SCl}$ & NIPTIOA & & & & & & & & \\
\hline $14 \mathrm{AH}$ & $\begin{array}{r}1-12 \\
13-24\end{array}$ & $\begin{array}{l}\text { MINTE X(4) } \\
\text { TEPAP }(4,17)\end{array}$ & $\begin{array}{l}52 \\
0.704000 .02\end{array}$ & $\begin{array}{l}\text { ME SH } \\
\text { TE MPP }\end{array}$ & $\begin{array}{l}\text { POINT } \\
\text { AT MFSH }\end{array}$ & PT & 52 & OURIIVG & I.VPUT & IIME & INTERVAL & 17 & IOEG. \\
\hline $4 \mathrm{AI}$ & $\begin{array}{l}1-12 \\
13-24 \\
25-30 \\
37-44 \\
49-6 n \\
61-72\end{array}$ & 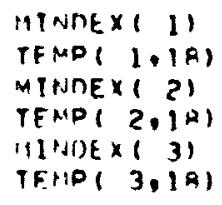 & $\begin{array}{c}1 \\
1.22400 n+03 \\
18 \\
1.061000+03 \\
19 \\
0.5120100+02\end{array}$ & $\begin{array}{l}\text { MESH } \\
\text { TEMP } \\
\text { MESH } \\
\text { TFMP } \\
\text { MESH } \\
\text { TEEAP }\end{array}$ & $\begin{array}{l}\text { PUINT } \\
\text { AT MESH } \\
\text { POINT } \\
\text { AT MFSH } \\
\text { POINT } \\
\text { AT MESH }\end{array}$ & $\begin{array}{l}P T \\
P T \\
P T\end{array}$ & $\begin{array}{c}1 \\
14 \\
19\end{array}$ & $\begin{array}{l}\text { OUFING } \\
\text { DURING } \\
\text { DURING }\end{array}$ & $\begin{array}{l}\text { IINPUT } \\
\text { I APUT } \\
\text { I NPUT }\end{array}$ & $\begin{array}{l}\text { TIME } \\
\text { TIME } \\
\text { TIME }\end{array}$ & $\begin{array}{l}\text { INTERVAL } \\
\text { INTERVAL } \\
\text { INTERVAL }\end{array}$ & $\begin{array}{l}18 \\
18 \\
18\end{array}$ & $\begin{array}{l}\text { IDEG. } \\
\text { IDEG. } \\
\text { IDEG. }\end{array}$ \\
\hline $44 \mathrm{~J}$ & $\begin{array}{r}1-12 \\
13-24\end{array}$ & $\begin{array}{l}\text { MINDEX } 14) \\
\text { TEMP }(4,18)\end{array}$ & $\begin{array}{l}52 \\
6.734000 \cdot 02\end{array}$ & $\begin{array}{l}\text { MESSH } \\
\text { TEMP }\end{array}$ & $\begin{array}{l}\text { POINT } \\
\text { AT MFSH }\end{array}$ & PT & 52. & DURING & INPUT & IIME & INTERVAL & 18 & IOEG . \\
\hline
\end{tabular}

- anter if SOP=i. nmit caros 15 ano is

IF SOP=?, OMIT CARO 16. LEAVE CARD 15 RLANK EXCFPT FOR SEGPWR (IN UNITS OF MICHOMOLES/CMMG3/SEC)

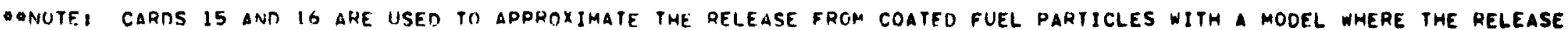
RATE IS DROPORTIONAL TO THE INVENTORY,I. THE IFEFINING DIFFERENTIAL EOUATION FOR THE IRELEASE CONSTANTIDR. IS

$$
\text { -I/AT = SEGPHR - LAMHAOI - FAI D }
$$

THIS EOUATION IS SOLVED FOR GOTH FISSILE AND FERTILE. PAPTICLFS, FACH WITH AN INTACT AND FAILEN FRACTION. THE INVENTCRY JF INTACT PAHTICLES HECOMES INUFETORY OF FAILEN PARTICLES WHEN THE FAILURE FRACTION IS INCREASED. THE SUN OF ALL a ROI'S IS EOUAL TO SUIJRCE.

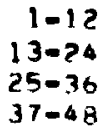

$25-36$
$37-48$

1-12

13024

$25-36$

$37-48$

$1-12$

$13-24$

$35-3 A$

$37-4 A$

$1-1$

$13-74$

$13->4$
$25-36$

$37=4$ A

\begin{tabular}{|c|c|}
\hline $\begin{array}{l}\text { SERPWH } 11 \\
\text { FF } 11,1) \\
\text { EN } 11,1) \\
\text { EN }(2,1)\end{array}$ & $\begin{array}{l}0.120010 n+01 \\
9.920000-01 \\
6.200 n 00-n t \\
0.000000\end{array}$ \\
\hline $\begin{array}{l}\operatorname{SF}\left(+P_{k} D(>)\right. \\
F F 1(2) \\
E N(1,2) \\
E N(?, 2)\end{array}$ & $\begin{array}{l}6.52 n n n 0101 \\
9.9200 n 0-01 \\
1.210000-05 \\
0.0 n 00110\end{array}$ \\
\hline 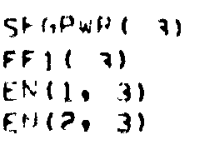 & $\begin{array}{l}6.6,40000+01 \\
9.590000-01 \\
2.1700100-05 \\
0.000000\end{array}$ \\
\hline $\begin{array}{l}\text { SF }(, P W P(4) \\
F F(1,4) \\
E N(1,4) \\
E N(?, 4)\end{array}$ & $\begin{array}{l}4.0100110001 \\
7.310000=01 \\
3.860000=05 \\
0.000000\end{array}$ \\
\hline
\end{tabular}

SPECIFIC FISSION POWER DURING INPUT IIME INTERVAL I (WATTS/CMEO3) FRACTION OF FISSION IN FISSILE MATERIAL DURING INPUT TIME INTERVAL I FHACTION OF FAILEI FISSILE MATERIAL DURING INPUT TIME INTERVAL I FPACTION OF FAILED FERTILE MATEAIAL DURING INPUT TIME INTERVAL I

SHECIFIC. FISSIOI. POWE IUIFING INPUT TIME INIERVAL 2 (WATTS/CMAO3) FRACTION OF FISSION IN FISSILE MATERIAL DURING INPUT TIME INTERVAL 2 FHACTION OF FAILEU FISSILF MATERIAL DURING INPUT TIME INTERVAL 2 FPACTION OF FAILFD FERTILE MATEAIAL DURING INPUT TIME INTERVAL 2

SFECIFIC FISSION POWEK DURING INPUP TIME INTERVAL 3 (WATIS/CMEÖ) FRACTION OF FISSION IN FISSILE MATERIAL DURING INPUT TIME INTERVAL 3 FAACTION OF FAILEO FISSILE AAIERIAL DURING INPUT TIME INTERVAL 3 FRACTION OF FAILEU FERTILE NAIERIAL DURING INPUT TIME INTERVAL 3

SHFCTFIC FISSION POWER RURIIUG I VPUT TIME INTERVAL 4 (WATTS/CMWOB) FAACTION IF FISSION IN FISSILE MATERIAL NURING INPUT TIME INTERṼAL FRACTION OF FAILFI FISSILE MATERIAL DURING INPUT TIME INTERVAL " FACTION OF FAILFT FISSILE MATERIAL DURING INPUY TIME INTERVAL 


\begin{tabular}{|c|c|c|c|c|}
\hline CARN & $\begin{array}{l}\text { CAPD } \\
\text { FORMAT }\end{array}$ & collumis & Sriland & $\begin{array}{l}\text { VALIIF } \\
\text { IISF }\end{array}$ \\
\hline $15 \mathrm{E}$ & & $\begin{array}{l}1-12 \\
13-24 \\
25-36 \\
37-48\end{array}$ & $\begin{array}{l}\text { SE(D, S } 5) \\
F F 1(5) \\
\text { EN }(1,5) \\
\text { EN }(2,5)\end{array}$ & $\begin{array}{l}6.0700010+01 \\
0.070000-01 \\
7.7200011=05 \\
0.000000\end{array}$ \\
\hline $15 F$ & & $\begin{array}{l}1-1 ? \\
13-24 \\
25-36 \\
37-48\end{array}$ & $\begin{array}{l}\text { SFGDWR G) } \\
F F 1(A) \\
F P(1, G) \\
E P(2, G)\end{array}$ & $\begin{array}{l}6.29(000+0) \\
8.720000-01 \\
4.1000110=04 \\
0.000000\end{array}$ \\
\hline 156 & & $\begin{array}{l}1-12 \\
13-24 \\
25-36 \\
37=48\end{array}$ & $\begin{array}{l}\text { SEGPWR } 7) \\
F F 1(7) \\
\operatorname{EN}(1,7) \\
\operatorname{EN}(2,7)\end{array}$ & $\begin{array}{l}6.010000+01 \\
3.470000-01 \\
1.330000-03 \\
0.000000\end{array}$ \\
\hline $15 \mathrm{H}$ & & $\begin{array}{l}1-12 \\
13-24 \\
25-36 \\
37-48\end{array}$ & $\begin{array}{l}\operatorname{SEGPWR}(A) \\
F F 11 \text { R) } \\
\operatorname{EN}(1,8) \\
\operatorname{EN}(2,9)\end{array}$ & $\begin{array}{l}5.920000+01 \\
8.190000-01 \\
2.410000=03 \\
0.1000000\end{array}$ \\
\hline$\frac{p}{1}$ & & $\begin{array}{l}1-17 \\
13-24 \\
25-36 \\
37-44\end{array}$ & 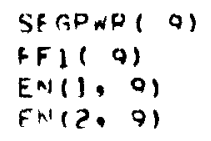 & $\begin{array}{l}4.050000+01 \\
7.090000=01 \\
7.720000=03 \\
0.0010000\end{array}$ \\
\hline $15 \mathrm{~J}$ & & $\begin{array}{l}1-12 \\
13-24 \\
25=36 \\
37-48\end{array}$ & $\begin{array}{l}\text { SEGPWR (10) } \\
\text { FFI(1N) } \\
\text { EN(1) IO) } \\
\text { EN(?,10) }\end{array}$ & $\begin{array}{l}6.010000001 \\
7.370000=01 \\
2.200000-03 \\
0.000000\end{array}$ \\
\hline $15 k$ & & $\begin{array}{l}1-12 \\
13-24 \\
25-34 \\
37-4 R\end{array}$ & $\begin{array}{l}\text { SF }\left(G P_{W R}(11)\right. \\
F F(11) \\
E N_{1}(1,11) \\
E N(2,11)\end{array}$ & $\begin{array}{l}6.010000+01 \\
1.0011000-01 \\
8.200000-03 \\
1.000000\end{array}$ \\
\hline 151 & & $\begin{array}{l}1-12 \\
13-24 \\
25-36 \\
37-44\end{array}$ & $\begin{array}{l}S E G P_{N} R(12) \\
F F(1,2) \\
E N(1,12) \\
F N(?, 12)\end{array}$ & $\begin{array}{l}A .0700100+01 \\
4.6011000=01 \\
9.200000=0.3 \\
0.000000\end{array}$ \\
\hline $15 M$ & & $\begin{array}{r}1-12 \\
13-24 \\
25-36 \\
37-44\end{array}$ & $\begin{array}{l}\text { SEGPWR }(13) \\
\text { FF } 1(12) \\
E+1(1,13) \\
E N(?, 13)\end{array}$ & 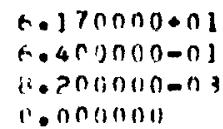 \\
\hline
\end{tabular}

OA SCETHTIRH

SUEC IFIC + ISSION POWEQ IUULING IIPUT TIME INTEPVAL 5 (WATTS/CMOA FRACTION OF FISSION IN FISSILE MATFRIAL DURING INPUT TIME INTERVAL 5 FRACTION OF FAILED FISSILE MATERIAL DURING INPUT TIME INTERVAL 5 FRACTION OF FAILED FERTILE MATERIAL DURING INPUT TIME INTERVAL 5

SPFCIFIC FISSION POWER DURIING INPUT TIME INTERVAL 6 (WATTS/CMWO3) FPACTION OF FISSIOA, IN FISSILE MATERIAL NURING INPUT TIHE INTERVAL FRACTION OF FAILEU FISSILE HATEHIAL DURING INPUT TIME INTERVAL 6 FRACTION OF FAIIEO FERTILE MATERIAL DUPING INPUT TIME INTERVAL 6

SPFCIFIC FISSIOH POWER DURING INPUT TIME INTEPVAL 7 (WATTS/CM*A3) FHACTION OF FISSION IN FISSILE MATERIAL DURING INPUT IIME INTERVAL FRACTION OF FAILED FISSILE MATERIAL DURING INPUT TIME INTERVAL FRACTION OF FAILED FERTILE MATERIAL DURING INPUT TIME INTERYAL

SPECIFIC FISSION POWER DURING IIPUT TIME INTERVAL 8 (WATTS/CMEG3) FRACTION OF FISSION IN FISSILE MATERIAL DURING INPUT TIME INTERVAL FKACTION OF FAILED FISSILE MATERIAL OURING INPUT TIME INTERVAL $B$ FHACTION OF FAILED FERTILE MATERIAL DIRING INPUT TIME INTERVAL

SPFCIFIC FISSION POWER DURIWG INPUT TIME INTERVAL 9 (WATTS/CM O3) FHACTION OF FISSION IV FISSILE MATERIAL OURING INPUT TIME INTERVAL FPACTION OF FATLFI FISSILF MATERIAL OURING INPUT TIME INTERVAL 9 FHACTIOH OF FAILFD FERIILE MATERIAL DURING INPUT TIME INTERVAL 9

SPECIFIC FISSION POWER DURING INPUT TIME INTERVAL 10 (WATTS/CMWB) FRACTION OF FISSION IN FISSILE MATERIAL OURINO INPUT TIME INTERVAL 10 FPACTIOII OF FAILED FISSILE MATERIAL DURING INPUT TIME INTERVAL 10 FHACTION OF FAILEO FERTILE MATERIAL DURING INPUT TIME INTERVAL IO

SPECIFIC FISSION POWER DURING INPUT TIME INTEPVAL II (WATTS/CMA3) FHACTION OF FISSION IN FISSILE MATERIAL DURING INPUT TIME INTERVAL II FRACTION OF FAILFD FISSILE MATERIAL. DURING INPUT TIME INTERVRL 11 FHACTIOH OF FAILFU FERTILE MATERIAL DURING INPUT TIME INTERVAL II

SPFCIFIC FISSION POWER DURING INPUT TIME INTERVAL I2 (WATTS/CM*B) FRACTION UF FISSION IN FISSILE MATERIAL DURING INPUT TIME INTERVAL 12 FRACTION OF FAIIEO FISSILE MATERIAL DURING INPUT TIME INTERVAL 12 FHACTION OH FAILFI FERTILE MATERIAL DURING INPUT TIME INTERVAL 12

SPECIFIC FISSICA POWER IURIHG INPUT TIME INTERVAL 13 (WATTS/CMAW3) FHACTIUN OF FISSION IN FISSILE MATERIAL DURING INPUT TIME INTERVAL I3

FRACTIOHA IF FAIIFU FISSILE MATERIAL DIRING INPUT TIME INTERVAL 13
FHACTION OF FAIIFU FFHTILE MATEHIAL DURING INPUT TIME INTERVAL 13

FRACTIOHA OF FAIIFU FISSILE MATERIAL DIIRING INPIIT TIME INTERVAL 13
FHACTIIN OF FAIIFE FFHTILE MATEHIAL DURING INPUT TIME INTERVAL 13

\author{
9 \\ 10
}




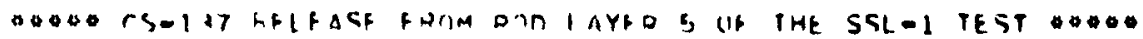

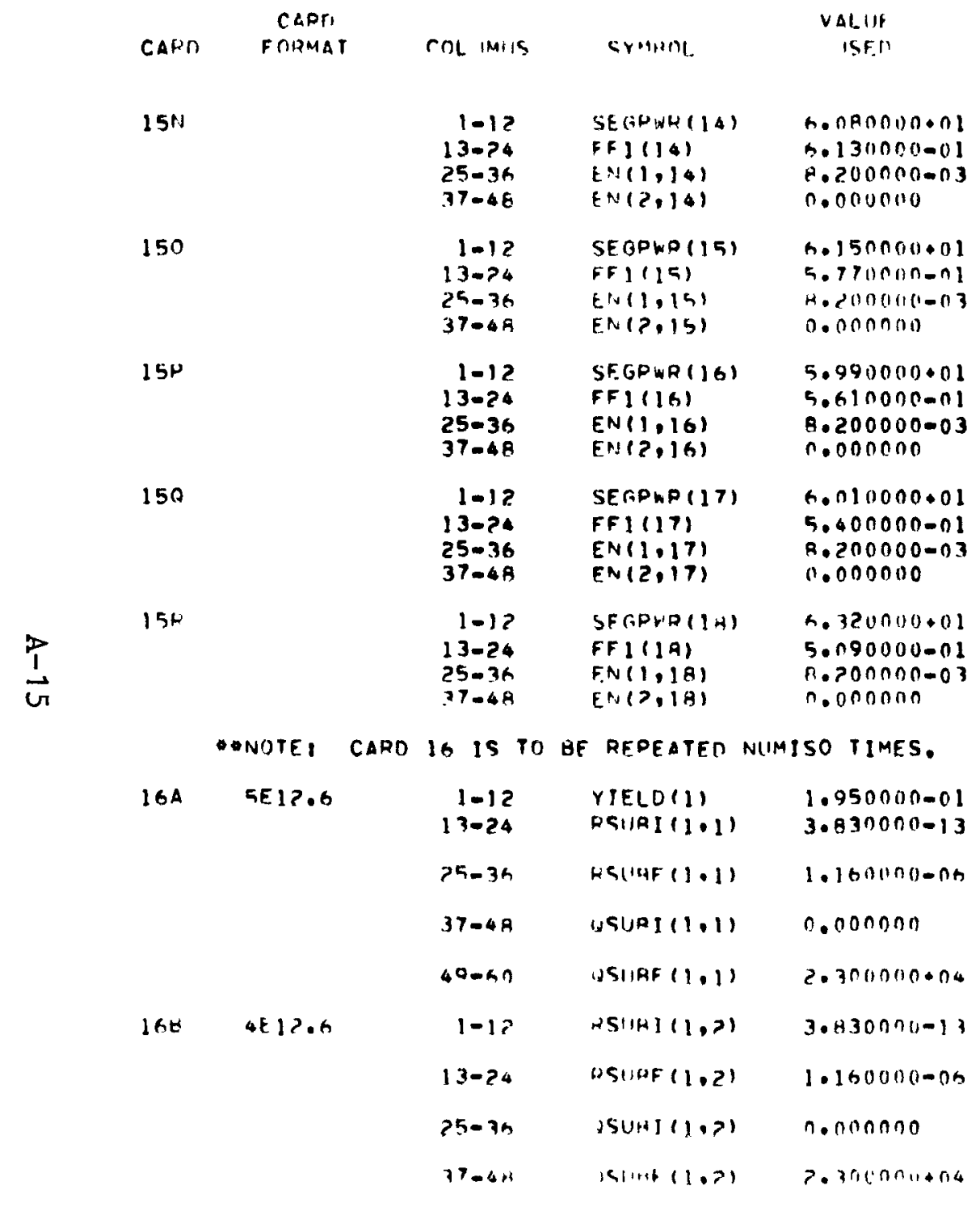

DF SCPTHTIUN

SPFCTFIC FISSION POWFR DURING INPUT TIME INTFHVAL IL (WATTS/CMAOB) FRACTION IH FISSIUN I' FISSILE HATHRIAL DURING INPUT TIME INTERVAL IA FRACTION OF FAILFC FISSILE MATERIAL DURING INPUT TIME INTERVAL IA FRACTIION OF FAILEO FEPTILE MATERIAL OURING INPUT TIME INTERVAL IA

SPECIFIC FISSIOH POWEH DURING INPUT TIME INTERVAL 15 (WATTS/CMMO3) FRACTIOH IF FISSIUN IN FISSILE MATFRIAL DURING INPUT TIME INTERVAL 15 FRACTIUN OF FATLEI FISSILE MATERIAL DURING INPUT TIME INTERVAL 15 FDACTIOPI OF FAILFO FEHTILE MATERIAL DURING INPUT TIME INTERVAL IS

SPFCIFIC FISSINII POWER DURI'GG INPUT TIME INTERVAL 16 (WATTS/CM:O3) FRACTIOI OF FISSION IN FISSILE MATERIAL DURING INPUT TIME INTERVAL 16 FRACTION OF FAILED FISSILE MATERIAL DURING INPUT TIME INTERVAL 16
FRACTION OF FAILFD FEPTILE MATERIAL DURING INPUT TIME INTERVAL 16

SPFCIFIC FISSION POWFR OURING INPUT TIME INTERVAL 17 (WATTS/CMOB) FRACTION OF FISSION IN FISSILE MATERIAL DURING INPUT TIME INTERVAL 17 FRACTION OF FAILEO FISSILE MATERIAL DURING INPUT TIME INTERVAL 17 FRACTION OF FAILFD FFRTILE MATERIAL DURING INPUT TIME INTERVAL IT

SPFCIFIC FISSIOH POWER RURIING INPUT TIME INTERVAL IE (WATTS/CMOA) FRACTIUN OF FISSION IN FISSILE MATERIAL DURING INPUT TIME INTERYAL 18 FRACTIOI OF FAILFO FISSILE MATERIAL DURING INPUT TIME INTERVAL 18 FPACTIIN TF FATLFO FERTILE MATERIAL DURING INPUT TIME INTERVAL IB
ING

FISSION YIFLO OF ISOTOPE I

RELFASF CONSTANT (AT TBASE) OF ISUTOPE 1 FOH INTACT SOUHCE OF TYPE FISSILF (1/SFC)

RELEASE CIHISTANT (AT THASE) OF ISIJTOPE I FOR FAILED SOURCE OF TYPE FISSII.E (1/SEC)

ACIIVATION ENERTY OF ISOTUPE I FOR INTACT SOLRCE OF TYPE FISSILE (CALIMOIE) (SEF CARO 12)

ACTIVATION FNEPTiY OF ISOTUPE 1 FOR FAILED SOURCE OF TYPE FISSILE (CAL A+TLLE) (SFF CARD I2)

RELLASF CORSTANT (AT TAASE) OF ISUTUPE I FOR INTACT SOURCE OF PYPE FERTILE (1/SEC)

RELEASE COR STANT (AT THASE) OF ISUTOPE I FOR FAILED SOURCE OF TYPE FERTILE (1/SEC)

ACTIVATIOA ENFPGY OF ISOTLPE I FOR INTACT SOURCE OF TYPE FERTILE (CAL BAOLE) (SFE CARQ I I)

ACIIVATION ENEPCY OF ISUTUPE I FOR FAILED SOURCE OF TYPE FERTILE ICAL MOLE) (SEE CARD IZI 


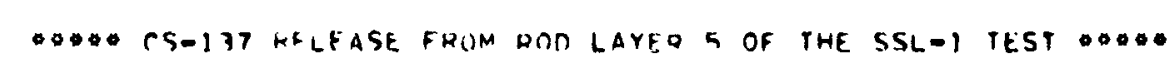
CARD
CARD
OENAT
coliness
Srannl
val lif
Crscionitis

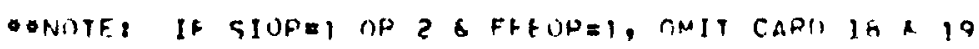

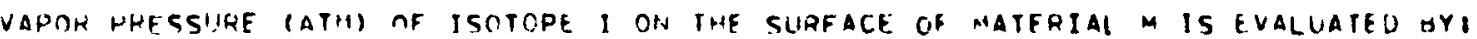

$P=\operatorname{EXP}(V) *(C R I T(I, M) *(1,1+S U M O O U M]) * C(I) / C O N M O N(I, M)$

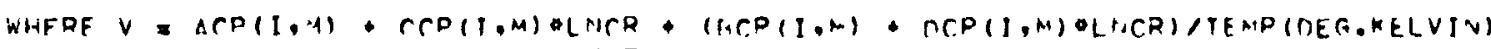

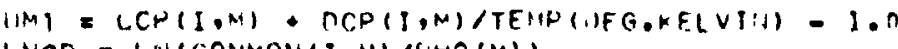

LNCR = LINTCOAHON(T,M)/NHO(M)

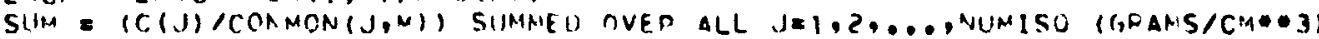

- UnNTEI card 19 is to be repeaten nimiso times for fach material m

CARIS 18 I 19 ARE PEPEATEN UNTIL INFACE(M) - NMESHP

\begin{tabular}{|c|c|c|c|c|}
\hline 19 & $112, E 12.6$ & $\begin{array}{r}1-12 \\
13-24\end{array}$ & $\begin{array}{l}\text { INFACF ( } 11 \\
\text { RHO ( } 11)\end{array}$ & $\begin{array}{r}19 \\
2.80001) 0-n 1\end{array}$ \\
\hline 19 & $5 E 12.6$ & $\begin{array}{l}1-12 \\
13-24 \\
25-36 \\
37-48 \\
49-60 \\
61=72\end{array}$ & $\begin{array}{l}\triangle C P(1,1) \\
\operatorname{ACP}(1,1) \\
\operatorname{CCP}(1,1) \\
\operatorname{UCP}(1 ; 1) \\
\text { CONUON(1) } 11 \\
\text { CRIT(1, 1) }\end{array}$ & $\begin{array}{r}\text { 7. RnOnOn+00 } \\
-4.730000 .04 \\
1.514000+00 \\
4.340000+03 \\
7.000000 .00 \\
5.600000=01\end{array}$ \\
\hline 18 & $112, E 12.6$ & $\begin{array}{r}1=12 \\
13-24\end{array}$ & $\begin{array}{l}\text { INFACE ( } 21 \\
\text { RHI ? ? }\end{array}$ & $\begin{array}{r}52 \\
1.720000 \cdot 00\end{array}$ \\
\hline 19 & $5 E 12.6$ & $\begin{array}{l}1-12 \\
13-24 \\
25-36 \\
37-44 \\
49=60 \\
-1-72\end{array}$ & $\begin{array}{l}\triangle C P(1,2) \\
\operatorname{ACP}(1,2) \\
\operatorname{CCP}(1,2) \\
\operatorname{DCP}(1,2) \\
\operatorname{CONPOAN}(1,2) \\
\operatorname{CP} 1(1,2)\end{array}$ & $\begin{array}{r}1.206000+01 \\
-3.903000+04 \\
-5.500000-01 \\
5.6900170-03 \\
7.000000+100 \\
4.400000=01\end{array}$ \\
\hline
\end{tabular}

MESH POINT NUMRER at THE RIGHT INTERFACE OF MATERIAL I DENSITY OF MATERIAL 1 (GRAMS/CMEO3)

ADSURPTION COEFFICIENT A OF ISOTOPE I AND MATERIAL I ADSODPTION COEFFICIENT B OF ISOTOPE I ANO MATERIAL I AISORHIIOR COEFFICIENT C OF ISUTOPE I AND MATERIAL I AOSURPTION COEFFICIENT D OF ISOTOPE I AND MATERIAL I MONOL AYER CONCFNTRATION OF ISTTOPE I ON MATERIAL I SURFACE (UM/GRAMI) CHITICAL FRACIION OF COMMON OF ISOTOPE I FOR CHANGE FROM LANGMUIR

TO FRUFNCLICH GEHAVIOH ON THE SUPFACE OF MATERIAL I (GRAMS/CMOB)

MESH POINT NUMBER AT THE RIOHT INTERFACE OF MATERIAL 2 DENSITY OF MATEPIAL 2 (GHAMS/CMNO3)

ADSUPHPION COEFFICIFNT A OF ISOTOPE I AND MATERIAL 2 ADSOPPTION COEFFICIENT $B$ OF ISOTOPE I ANO MATERIAL $?$ ADSORPTION COEFFICIENT C OF ISOTOPE I AND MATERIAL 2 AISOPPTION COEFFICIENT $D$ OF ISOTOPE I ANO MATERIAL WUNOI AYFR CONCFITKATION OF ISUTOPE, ON MATERIAL 2 SURFACE (UM/GRAMI CPITICAL FHACTIOIN OF CONMON OF ISOTOPE I FOP CMANGE FROM LANGMUIR TO FHUENLIICH HEHAVIOH ON THE SURFACE OF MATERIAL 2 (GRAMS/CMa-3) 


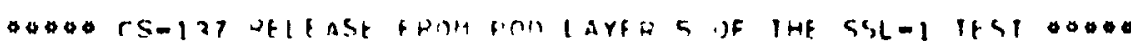

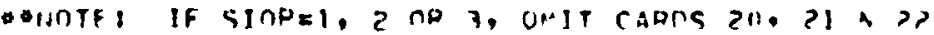

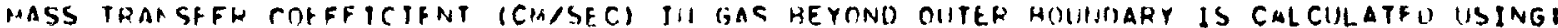

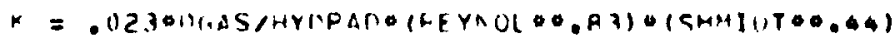

WHERE:

OGAS = DGASOU(1COOLT•273.1/273.1**1.75/PGASO

PEYNOL = 4.0FLOWMT/IPIOAYIRAMOVISCOSI

SHNIOT E VISCOS/(PGNSO/IAR.06*(COCLT+273.)) OOSAS)

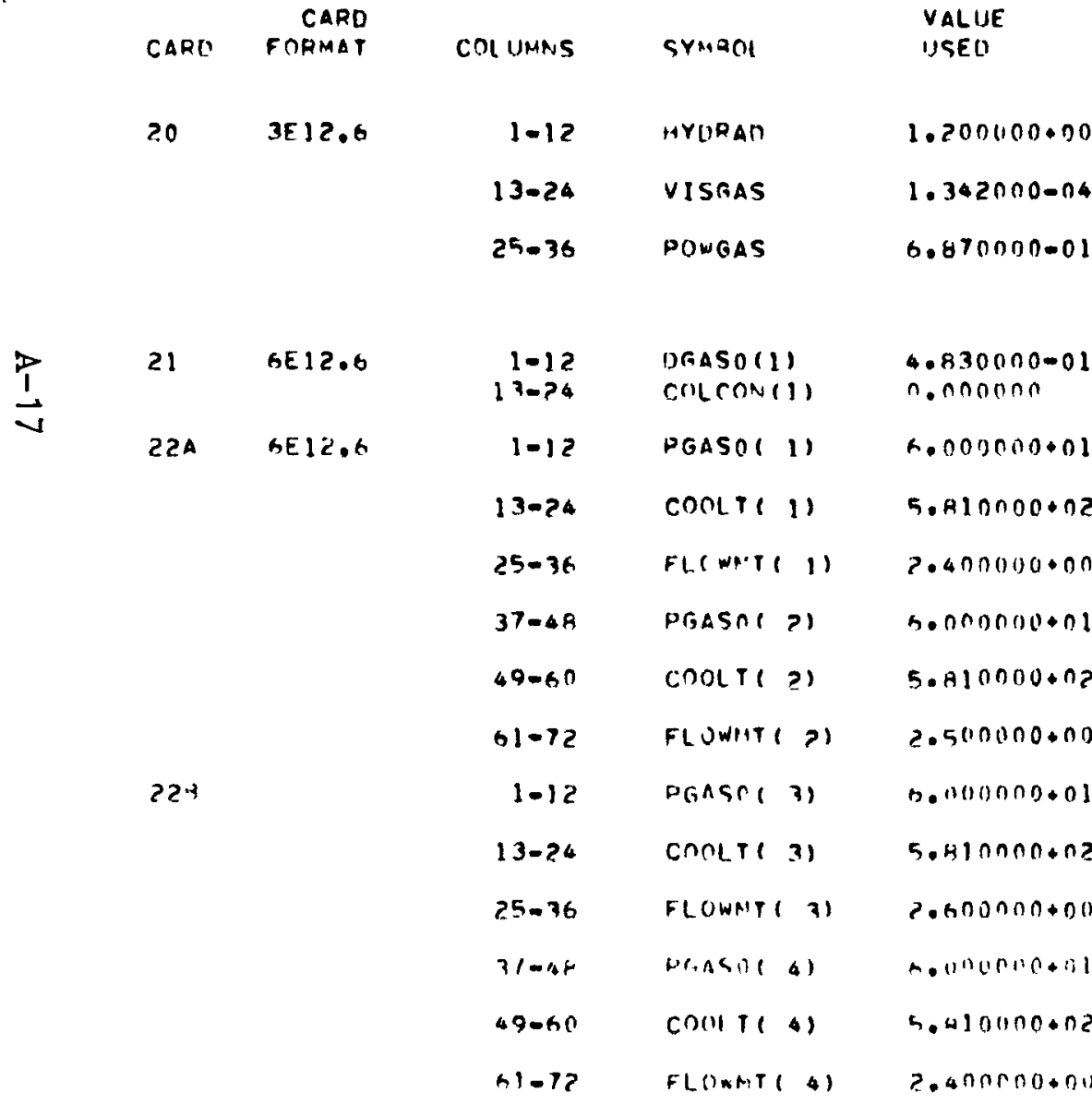

DESCRTDTION

HYDRAIILIC RIAMETFR OF SIMGLE FLOW CHANNEL (CM)

VISCCSITY OF GAS OUTSIOE OUTER BOUNDARY AT TBASE (GK-MOLFS/CM-SEC)

EXPONFNT OF TEMPERATURE IN IHE EOUATION

VISCOS - VISGAS* ( (CUOLT+273.)/(TBASE+273.) )*POWGAS

DIFFUSION COEFFICIENT OF ISOTOPE I IN GAS AT STP (CM" CONCEITPATION OF ISOTIDE I IN BJUNDARY GAS (MICROMOLES/CM-O3)

GAS PRESSUHE OUTSIDE OUTEH BOUNOARY DURING INPUT TIME INTERVAL I (ATM)

GAS TFMPERATURE OUTSIDE OUTER BOUNOARY DURING INPUT TIME INTERVAL I (DFG. C)

SIHGLE CHENNEL TIAS FLCIM OUTSIDE OUTER BOUNDARY DURING INPUT TIME INTERVAL I (GMOMOLES/SEC)

GAS PRESSIIPE OUTSINE MUTER HOUNOARY OURING INPUT TIME INTERVAL 2 (ATM)

GAS TFMPEDATUHE DUTSIUE OUTER RUUVMARY DURING INPUT TIME INTERVAL 2 (OFG. C)

SINGLE CHANNFL GAS FL'JW OUTSIDE OUTE BOUHDAHY UURING INPUT TIME INTELVAL? IGMOMOLES/SECI

GAS PRECSUHE OUTSINE OIITEK GOUNIJARY DURING INPUT TIME INTERVAL 3 (ATM)

GAS TFMPEPATURF OUTSIDF OUTER RUUNDARY DURING INPUT TIME INTERVAL 3 (TIFG. C)

SINGIF CHANNEL GAS FLOW OUTSIUE OUTER ROUNDARY DURING INPUT TIME IHTFBVAL 3 (GIA-CILLESTSEC)

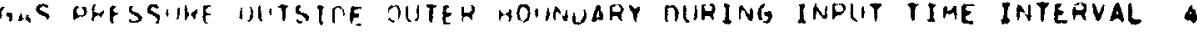
(ATM)

GAS TFMPFRATIRF nUTSIOF OUTEP ROUNDARY DIJRING INPUT TIME INTERVAL a (1)F(.. C)

SINGLF CHANIJL GAS FLUW OUTSIUE. OUPER BUUNUARY DURING INPUT TIME JUTFPVAL 4 (OAMEIOLFSISFC) 


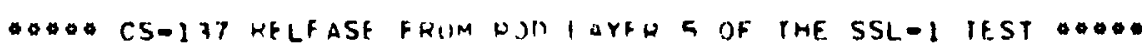

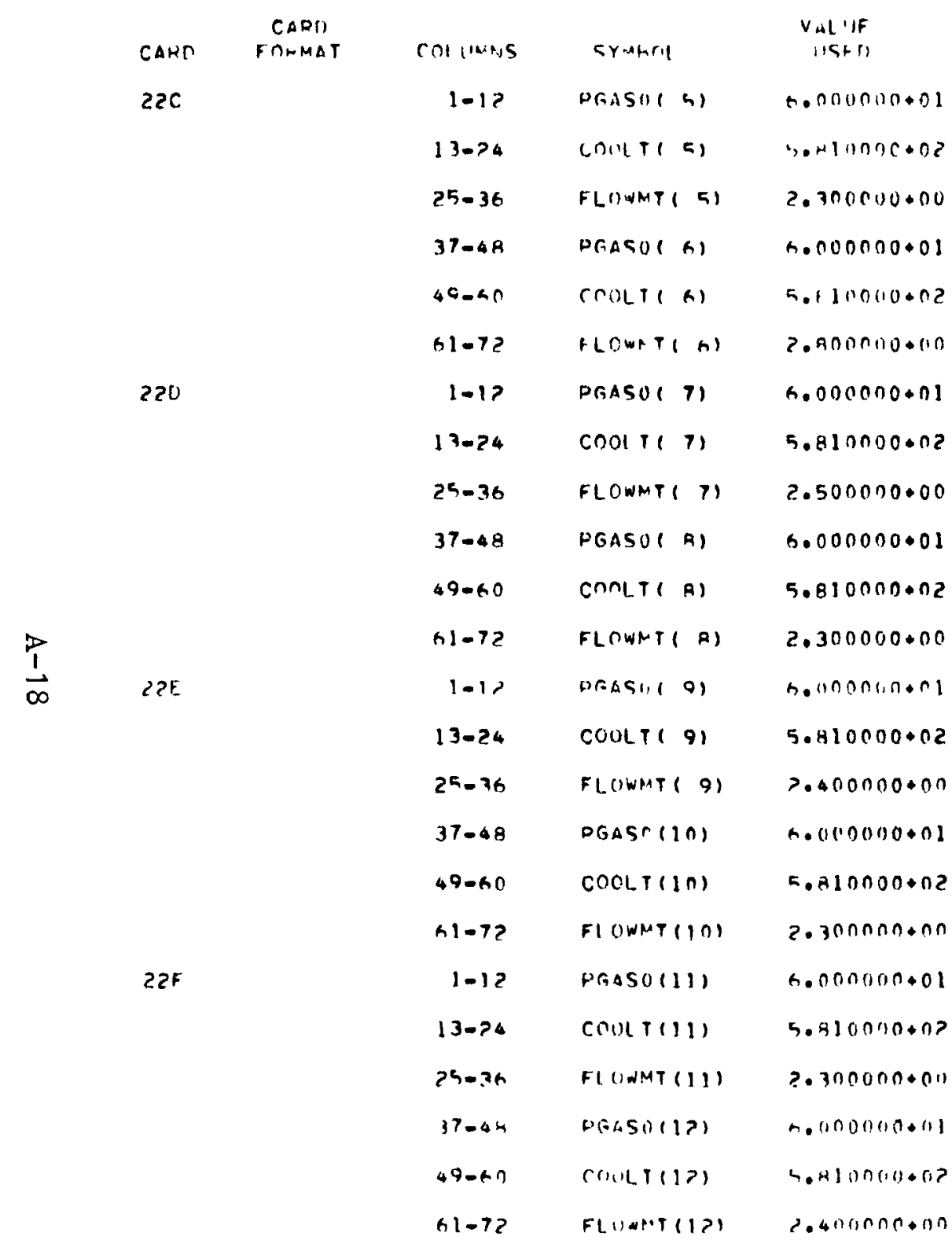

TESTLPTHA

GGS PHESSURE OUISIOF OIIIEN HOUNIARY DUHING INPUT TIME INTERVAL 5 ( $\angle$ TA)

AS TFMDFPATURE MIITSIIIE OUTEH HUUNDAHY UURING INPUT TIME INTERVAL 5 (IIF, C) C)

SINGLE CHANHEL GAS FLOW OUTSIUE OUTER BOUNDARY OURING INPUT TIME INTFRVAL 5 (GM-MOLES/SEC)

GAS PRFSSURE OUTSIDE OUTER HOIJNUARY DURING INPUT TIME INTERVAL 6 (ATM)

GAS TE MPFFATURE OUTSIDE NUTER HOUNDAPY UURIIIG INPUT TIME INTERVAL 6 (IIFG. C)

SIPAI E CHAPPJEL TAS FLOW OUISIOE OUTER AOUNDARY DURING INPUT TIME INTERVAL 6 (GMAMOLES/SEC)

GAS PRESSUPE OIITSIIIF OUTER HOUNDAKY OURING INPUT TIME INTERYAL (ATM)

GAS TEMPERATUHF OUTSIOE OUTER HOUNDARY DURING INPUT TIME INTERVAL 7 (OFG. C)

SINGLE CHANNEL GAS FLOW OUTSIDE OUTER BOUNDARY DURING INPUT TIME INTERVAL 7 (GM-MOLES/SEC)

GAS PRESSURE OUTSIDE OUTER BOUNDARY DURING INPUT TIME INTERVAL 8 (ATM)

GAS TEMPERATURE OUTSINE OUTER ROUNDARY DURIHG INPUT TIME INTERVAL B (DFG. C)

SINGLE CWANNEL GAS FLUW OUTSIDE OUTER BOUNDARY DURING INPUT TIME TNTFPVAL \& (GM-MOLES/SEC)

GAS PHFSSUPE OUISITF UTFK ROUHOAKY DURING INPUT TIME INTERVAL 9 (ATM)

GAS TEMPEPATURE OUTSIUE OUTER BOUNOARY DURING INPUT TIME INTERVAL IDFG. CI

SINGLE CHANNEL GAS FI OW OUTSIDF OUTER BOUNDARY DURING INPUT TIME INTERVAL 9 (GM-MOLES/SEC)

GAS PRECSUPE OUTSICE TUTER HOUNDARY DURING INPUT IIME INTERVAL 10 (ATM)

RAS TFMPFPATURE OUTSIDE OUTER BUUNOARY DURING INPUT TIME INTERVAL 10 (DFE. C)

STHGLF CHANNFL GAS FLOW DUTSIDE OUTER BOUNDAFY DURING INPUT TIME INTENVAL 10 (GMAMOLES/SEC)

GAS PHFSSILE UUITSIDE UUTER GOUNDARY DIJRING INPUT TIME INTERVAL II (ATH)

GAS TEMPEFATIIRE OUTSIDE OUTER RUIINDARY DIJRING INPUT TIME INTERVAL 1 (NEG. C)

SINGLE CHANNFL GAS FLOW OUTSIDE OUTKR BOUNUARY DURING INPUT TIME INTERVAL 11 (FMAMOLES/SEC)

GES PHFSSIHE GHTSIDF OUTEK BOUMHARY DIRING IIAPUT TIME INTERVAL IZ $(A T *)$

GAS TE MPEHGTIWF OIISIIIF OUTER ROUVUARY DURIAS INPUT TIME INTERVAL 12 $(1, F \mathrm{G}, \mathrm{C})$

SINGIE CHANNFI TAS FLUW OUTSIDF OUTER GOUNOARY DURING INPUT TIME

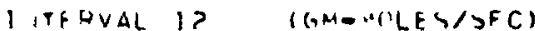




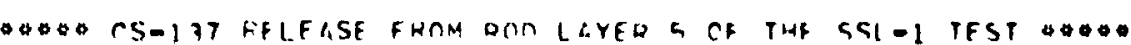

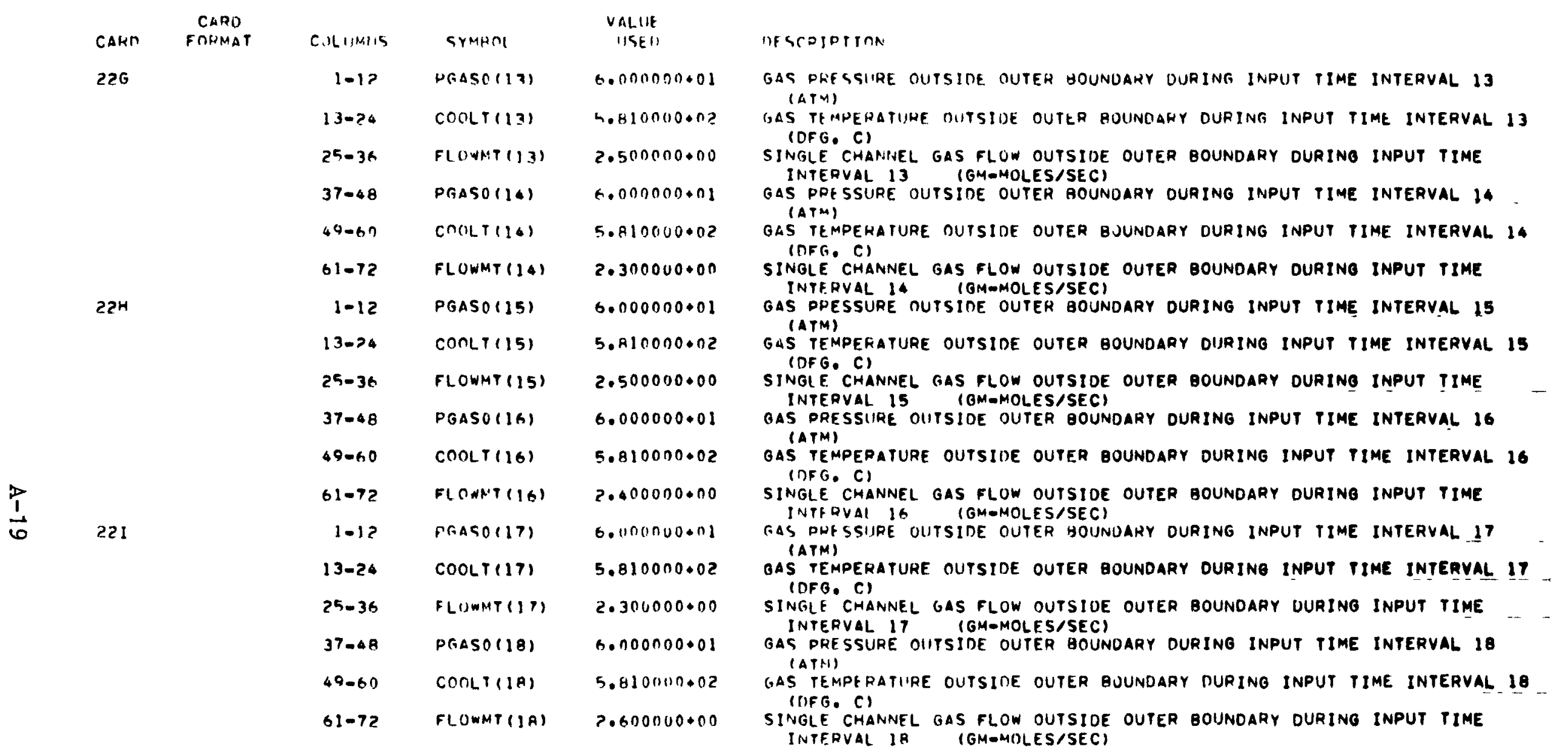

OONOTF: IF VZOP DOES ROOT EQIIAL 2, LNT CAN RE LEFT RLANK. if aLSO ISHAPE a 1 OR 3, DZ CAN BE LEFT BLANK. 
CALCULATIONAL TIME STEP (UAYSI S. OnODOn-OI

\begin{tabular}{|c|c|}
\hline $\begin{array}{l}\text { MESH } \\
\text { POINT }\end{array}$ & $\begin{array}{l}\text { UISTANCE } \\
\text { (CM) }\end{array}$ \\
\hline 1 & $-1.1350 n n-02$ \\
\hline 2 & $1.135000-0 ?$ \\
\hline 3 & $3.40500 n-0 ?$ \\
\hline 4 & $5.675000-02$ \\
\hline 5 & $7.94500 n=02$ \\
\hline 6 & $1.021500-01$ \\
\hline 7 & $1.248500-01$ \\
\hline a & $1.475500=01$ \\
\hline 9 & $1.702500-01$ \\
\hline 10 & $1.929500-01$ \\
\hline 11 & $2.156500-01$ \\
\hline 12 & $2.3835 n 0=01$ \\
\hline 13 & $2.610500=01$ \\
\hline 14 & $2.837500-01$ \\
\hline 15 & 3.064500002 \\
\hline 16 & $3.291500=01$ \\
\hline 17 & $3.518500-01$ \\
\hline $1 A$ & $3.745500-01$ \\
\hline 19 & $7.9725 \cap 0-01$ \\
\hline 20 & $4.199500-01$ \\
\hline 21 & $4.335500=01$ \\
\hline 22 & $4.471500-01$ \\
\hline 23 & $4.61) 7500=01$ \\
\hline 24 & $4.74 .35 n n=01$ \\
\hline 25 & $4.979500-01$ \\
\hline 26 & 5.015500001 \\
\hline 27 & $5.15150 n-01$ \\
\hline 28 & $5.787500=01$ \\
\hline 29 & $5.423500=01$ \\
\hline $3 n$ & $5.553500-01$ \\
\hline 31 & $5.695500-01$ \\
\hline 32 & $5.831500=01$ \\
\hline 33 & $5.96750 n-01$ \\
\hline 34 & $0.103500=01$ \\
\hline 35 & $6.239500-01$ \\
\hline 34 & 6.3755nn-n1 \\
\hline 37 & $6.511500-01$ \\
\hline 38 & $6.6475 n 0-01$ \\
\hline 39 & $0.763409=01$ \\
\hline 40 & B.019499-01 \\
\hline 41 & $7.055499=01$ \\
\hline 47 & $7.191499-01$ \\
\hline 43 & $7.327499-01$ \\
\hline 44 & $7.463499-01$ \\
\hline 45 & $7.549490-01$ \\
\hline 46 & $7.735490=01$ \\
\hline 41 & $1.47140 .0-11)$ \\
\hline
\end{tabular}

SUUPCE

(RiA/CC/SEC)

CUPRENT

$7.462335=03$ $7.462335-13$

$7.462274-03$

$7.462141=03$

7.461927 .03

$7.461674-03$

$7.461169-03$

$7.440547-03$

$7.459866-03$

$7.458948=03$

$7.457815-03$

7.456430003

$7.454755-03$

$7.454755-03$

$7.452745-03$

$7.450349-03$
$7.447512-03$

$7.447512=03$
$7.444178-03$

$7.440289=03$

$6.121315-02$

$5.764004-02$

$5.552344-02$

$5.333635-0 ?$

$5.333435=0$ ?

5. 113a1n-nz

$4.892356=n 2$

$4.671193=02$
$4.450647-02$

$4.231426-02$

$4.014202=02$

$3.799592-02$

$3.598148=02$

$3.390356-n 2$

$3.170634=0$

$3.170634-02$

$2.977340-02$

?.782779-0?
$2.593213=0 ?$

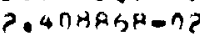

2. $229939-02$

2. $056594-n 2$

$1.888909-02$

$1.727164-02$

$1.571235-02$

- $571>35=n$ व

$1.27 n 927-02$
$1.138324-n 2$

- 0n511R-nz

$8.769514=03$

$7.5734 \mathrm{~A}>-n \mathrm{H}$ n. nonnon

?.794465-09

$2.797750-09$

$2.799200=09$

?. $A U O R 18=09$

?. $8026 \cap B=09$

?. $204560-09$

$2.806670-09$

$2.809924-09$

$2.811301=09$

2.913776-09

2.816317-09

2.RIARA5-09

$2.821440=109$

?. A23935-09

2.826322-09

?.R2A557-09

2.A30600-09

$2.013624=09$

n. nunnon

0.1000000

n. nnornon

n. nonnon

0.000000

000000

0.000000

0.000000

0.000000

0.000000

n. nuonon

c.00000n

0.000000

n. nunoun

n.no00no

0.000000

D. nonnas

c.nonono

n. nonooo

n. nonחno

0. nunoon

n. nonono

0.000000

n. n60000

0.00nnon

r.onoon

nenonon (MICHOHOLES/LC)

1.4211+n-na
$0.00000 n$

6. $270435-11$

$1.244189-10$

$1.874200-10$

$2.405921-10$

$3.172790-10$

$3.750138-10$

$4.373136-10$

$5.004613-10$

$5.626969-10$

3. $248526-10$

$6.864789-10$

$7.470299-10$

$8.062712-10$

$8.630333-10$

$9.159112-10$

$9.530358-10$

$1.002034-09$

$1.101090-n 9$

1. 1790RK $=08$

1. $061725-19$

$1.040574=09$

1. $010532=09$

..897089-10

$9.603312=10$

$9.2 A 7182-10$

$0.952523-10$

$0.603552-10$

a. $244508-10$

7.879437-10

$7.511962-10$

$7.145166-10$

6.7A1547-10

$6.423050-10$

$6.071171-10$

$5.727069-10$

$5.391718-10$

5. $054038-10$

$4.7511001-10$

$4.447714-10$

$4.447714-10$
$4.157445-11$

? $157445-11$

$3.62187 A-10$

$3.379948-10$

3.157?72-1n

$2.955945-113$
CIFF COEF

( $S 6 \mathrm{CM} / \mathrm{SE}$ C)

$2.514210-05$

$2.310347-05$

2.120685-05

$.944416-05$

. $780766-05$

$.628993-05$

1. 4AR3RB-05

$1.35 R 274=05$

126963-05

1. $02.562-05$

$9.302446-06$

. 302446-06

$7 A 2=06$

$7.637592-06$

$6.906090-06$

$6.235746-06$

$5.622269-06$

$5.061606-06$

$7.092496-09$

$6.7 A 2323=09$

$6.602133-09$

$6.426072-09$

$6.254063=19$

$6.086027-09$

5.921R90-09

$5.761576-09$

$5.605011-09$

$5.452123=09$

5.3n2942-09

5.157093-09

5.014812-09

4. $875926=09$

$4.740371-09$

$4.608077=09$

$4.4789 R 3=09$

$4.3530 ? 1-04$

$4.230130=09$

$4.11 n 246-09$

$3.993310=09$

$3.879259-09$

3.76An34-109

$3.659570-09$

$3.553833=09$

3.450743-09

$3.350>50=09$
$7.752302=09$
(DEF. C)

1.224000 .03

1.214412 .03

$1.204824+03$

$195235+03$

$.185647+03$

.176059003

$1.166471+03$

$1.156882+03$

$137706 \cdot 03$

.128118 .03

118529003

100941.03

1.090353003

1.089765 .03

1.080176 .03

$1.070588+03$

1.061000003

.512000 .02

9.473431 .02

9.450324002

. $07217+02$

9.404110 .02

$9.381003+02$

$9.357895 \cdot 02$

$9.334788 \cdot 02$

9.311681 .02

. $288573+02$

$.265466+02$

$9.242359+02$

9.219252 .02

$9.196145+02$

9.173037 .02

9.149930 .02

$9.126823 \times 02$

9.103716 .02

. ก80609.02

$9.057501+02$

$9.034394+07$

9.011287.02

8.988179+02

.

. $941965+0$ ?

$4.912858+0$ ?

R. $895751+02$

8.812643002

.. $849536+02$

PRINT TIME (UAYS)

$1.2050 n 0+02$

PRESSIIRF
(ATM)

ADSORPTION

HATIO

$1.017369-08$

8.718656-09

. $456565-09$

3. $364100=09$

$5.420329-09$

$.606660-09$

$3.906602-09$

3.305555-09

$2.790624=08$

$2.350434=09$

$1.974979-09$

1.65547200

$1.384209-09$

$1.154456=09$

$9.603356-10$

$7.967314-10$

$6.591988-10$

$5.438862-10$

$5.435576-10$

$.671432-10$

4.253244010

$3.864229-10$

$3.503109-10$

$3.168633=10$

$2.859560-10$

$2.574651-10$

$2.312659-10$

$2.072328=10$ 


MESH DISTANCE CONCENTHETIUN
POINT
(CM)

$$
\begin{gathered}
\text { SUUPC.F } \\
(A M / C C / \text { SEC })
\end{gathered}
$$

CIIRRENT (MM/SIJC. $/$ SLC)

ISOCM CSECL
ISOCF

$? .42 ? 749-10$
$3.493429-10$

nononison

n. noonon

n. noonon

0.000000
$2.301778-10$

?. $711479-10$
$3.063820=10$ $? .9731 \times 2-09$ ?. RA4 179000 $2.004532-03$ $1.17844 \mathrm{C}-03$
TEMPERATURE (NEG. C)

$4.826429+0 ?$

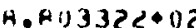
A. $780515+05$ ..7 $75107+0$, B. 734000012
PRESSURE

(ATM)

$9.968810-12$

$1.648811-12$

$5.602671-12$

$3.791713-12$
ADSORPTION RATIO

$1.000000+00$ $1.000000+00$ $1.000000+00$ $1.000000+00$ $1.000000 \cdot 00$

TOTAL ISUTOPE INVENTORY FOR THE FOLLONING AREAS

DESCHIPTION

ACCUMIJL ATEO BIATH AMOIJNT IN REGION,

$$
1 \text { - FIIEL }
$$

AMOUNT LEFT IN PARTICLES

AMOUNT IN PARTICLES - MATRIX

RELEASE FROM OUTER ROUNDARY RELEASE DUE TO PURGE TOTAL SYSTEM RELEASE

$$
\text { PSI०C }
$$

$(M M / S O C M-S E C)$

$2.317479-10$

SINFF LAST CALCULATFN TIME:
CUPIES

$2.331974 \cdot 00$

\section{$2.531132-03$ \\ $1.087759-02$ \\ $2.318047+00$ \\ $2.32 n 579 \cdot 00$ \\ $5.211203-0$ \\ 0.000000 \\ $5.211203=00$}

CHI

(MM/SOCM-SEC)

FOR ISOTOPE I
$0.196006-01$

$4.420328-02$

$0.00000 n$

\section{SOURCE INTEGRAL OVER DISTANCF \\ 1.15131 \\ CONSERVATION INTFGRAL}

$4.014459-12$ 


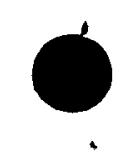

GENERAL ATOMIC COMPANY

P. O. BOX 81608

SAN DIEGO, CALIFORNIA 92138

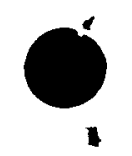

